\title{
Oxindole as starting material in organic synthesis
}

\author{
Ghodsi Mohammadi Ziarani, ${ }^{\text {* }}$ Parisa Gholamzadeh, ${ }^{\text {a Negar Lashgari, }}$ a,b \\ and Parvin Hajiabbasi ${ }^{\mathrm{a}}$ \\ ${ }^{a}$ Department of Chemistry, Alzahra University, Vanak Square, P.O. Box 1993891176, \\ Tehran, Iran \\ ${ }^{b}$ School of Chemistry, College of Science, University of Tehran, P.O. Box 14155-6455, \\ Tehran, Iran \\ E-mail: gmziarani@hotmail.com; gmohammadi@alzahra.ac.ir
}

\begin{abstract}
This review highlights the advances in the use of oxindole as starting material in the synthesis of various organic compounds and drugs. The reactions can be performed on different reactive sites of oxindole which are the carbonyl group, C-3 site, nitrogen atom, and aromatic ring. In addition, the roles of oxindole in one-pot and domino reactions are discussed.
\end{abstract}

Keywords: Oxindole, cat's claw, one-pot reactions, domino reactions, Vilsmeier reactions

\section{Table of Contents}

1. Introduction

2. Reactions on the C-3 Site

2.1. Condensation reactions

2.1.1. Knoevenagel condensations

2.1.2. Condensation reactions of oxindole with isatin derivatives

2.1.3. Condensation reactions with ninhydrin

2.1.4. Condensation reactions with carbaldehydes

2.1.5. Condensation reactions with esters and nitriles

2.2. Reactions with halogenated compounds

2.3. Reactions with alcohols

2.4. Michael additions

2.5. Reactions with nitriles

3. Reactions on the Nitrogen Atom

3.1. Reactions with halogen compounds

3.2. Reactions with alcohols

3.3. Reactions with anhydrides 
3.4. Reactions with alkynes

3.5. Competition between $\mathrm{C}-3$ and nitrogen alkylation

4. Reactions on the Carbonyl Site

4.1. Reactions at the carbonyl carbon

4.2. Reactions on the carbonyl oxygen

4.3. Competition between acylation at nitrogen and the carbonyl group

5. Reactions on the Aromatic Ring

5.1. Bromination of oxindole

5.2. Acylation of oxindole

5.3. Hydroxylation of oxindole

5.4. Oxindole sulfones and sulfonamides

6. Simultaneous Participation of More than One Site in Reactions

6.1. C-3 and carbonyl group

6.2. C-3 and nitrogen atom

6.3. Carbonyl group and nitrogen atom

6.4. C-3 atom and aromatic ring

6.5. Participation of three sites in reaction

6.6. Vilsmeier reactions of oxindole

7. One-Pot Reactions

8. Domino Reactions

9 Conclusions

10 Acknowledgements

References

\section{Introduction}

Oxindole is the core structure in a variety of natural products and drugs. For example there are two groups of oxindole alkaloids in the cat's claw plant Uncaria tomentosa (Rubiaceae): pentacyclic oxindole alkaloids (POAs) and tetracyclic oxindole alkaloids (TOAs). POAs include pteropodine, isopteropodine, speciophylline, uncarine F, mitraphylline, and isomitraphylline, and TOAs include rhynchophylline, isorhynchophylline, corynoxeine, and isocorynoxeine (Scheme 1). Cat's claw is a woody, tropical vine indigenous to the Amazon rainforest and other tropical areas of South and Central America. It is used for the treatment of infection, cancer, gastric ulcers, arthritis and other inflammatory processes. ${ }^{1-5}$

Oxindole derivatives ${ }^{6}$ have demonstrated significant potential for use in a wide range of biological applications such as NMDA antagonist ${ }^{7}$ and calcium channel blockers ${ }^{8}$ as well as antiangiogenic, ${ }^{9}$ anti-cancer, ${ }^{10}$ and analgesic effects. ${ }^{11}$ 


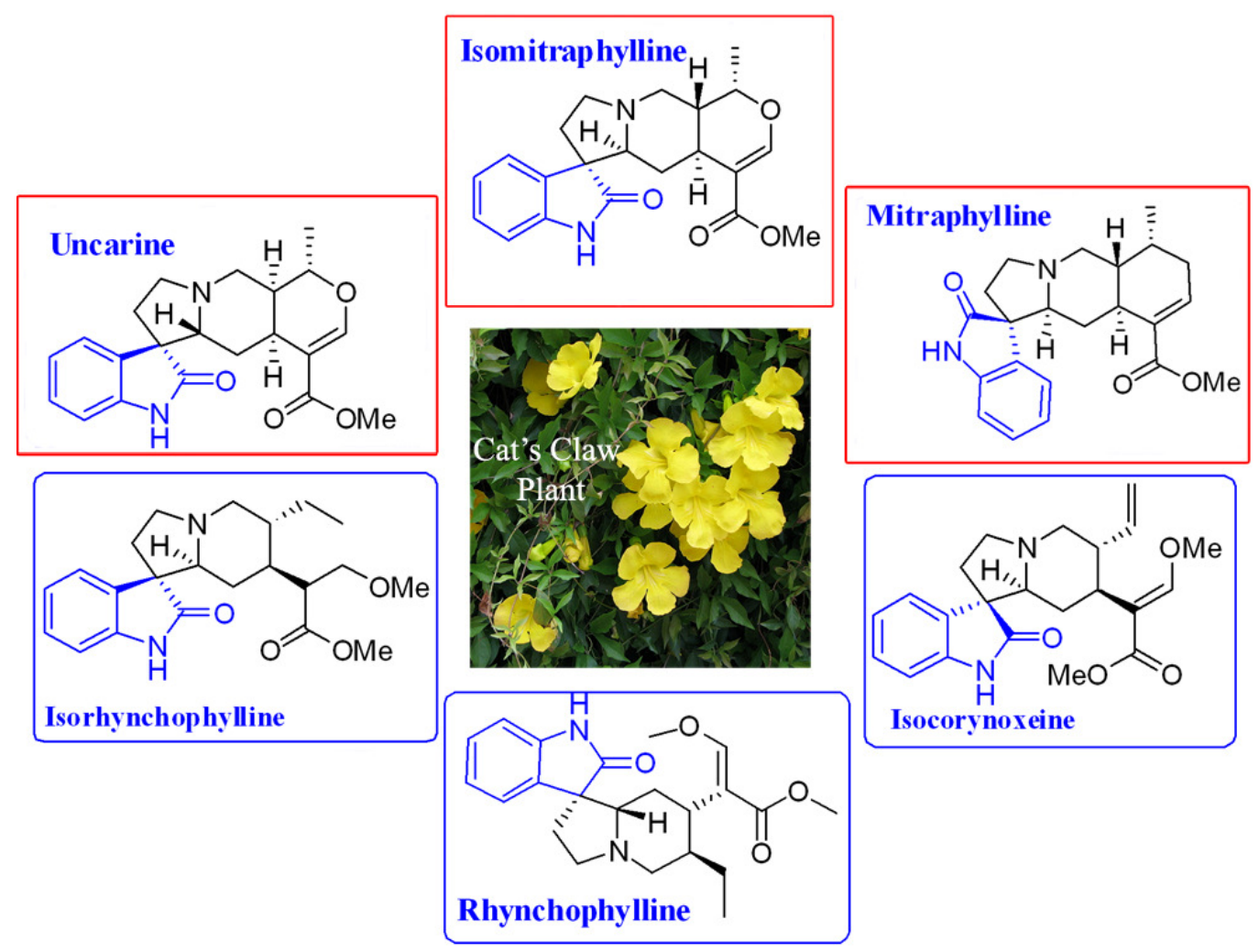

\section{Scheme 1}

As shown in Scheme 2, oxindole is reactive at four different positions, specifically the nitrogen atom 1, carbonyl group 2, carbon atom 3 , and the aromatic ring.

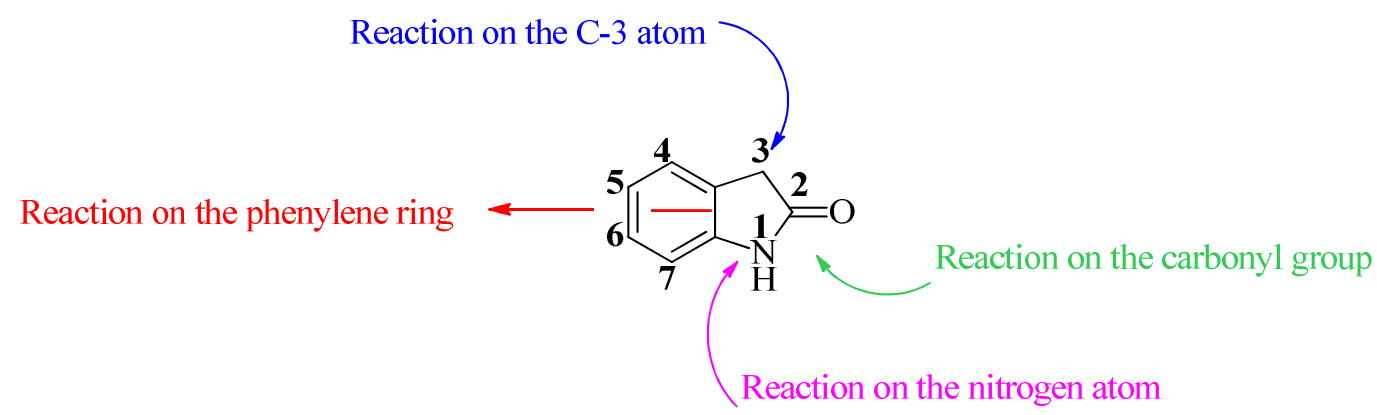

Scheme 2. Four positions of oxindole reactivity.

Oxindole and its derivatives are also versatile substrates in one-pot and domino reactions. In this review the focus is on the applications of oxindole in various organic reactions.

\section{Reactions on the $\mathrm{C}-3$ site}

In oxindole, C-3 has two acidic hydrogen atoms that can be reacted separately or together. These 
reactions can be divided into condensation reactions, Michael addition reactions, as well as reactions with nitriles, alcohols, and halogenated compounds.

\subsection{Condensation reactions}

2.1.1. Knoevenagel condensations. Condensation reactions of oxindole $\mathbf{1}$ and benzaldehyde derivatives 2 in the presence of piperidine were reported by Wahl and Bagard in 1909 (Scheme $3) .{ }^{12-14}$ This reaction was also examined under reflux conditions in EtOH in the presence and absence of piperidine. ${ }^{15-17}$

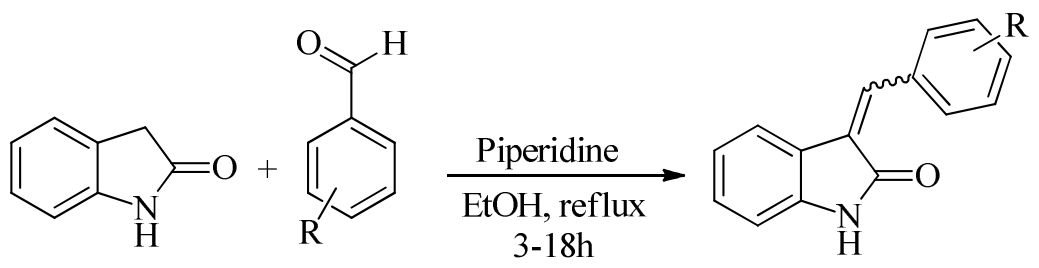

1

2

3

\section{Scheme 3}

Many years later, in 1998, aldehydes and ketones were condensed with oxindole $\mathbf{1}$ in the presence of $\mathrm{KF}-\mathrm{Al}_{2} \mathrm{O}_{3}$ and under microwave irradiation, forming good yields of products (81-94\%) (Scheme 4). These condensation products $\mathbf{4}$ and $\mathbf{5}$ are useful for their biological properties and they can be used as synthons in organic synthesis. ${ }^{18}$

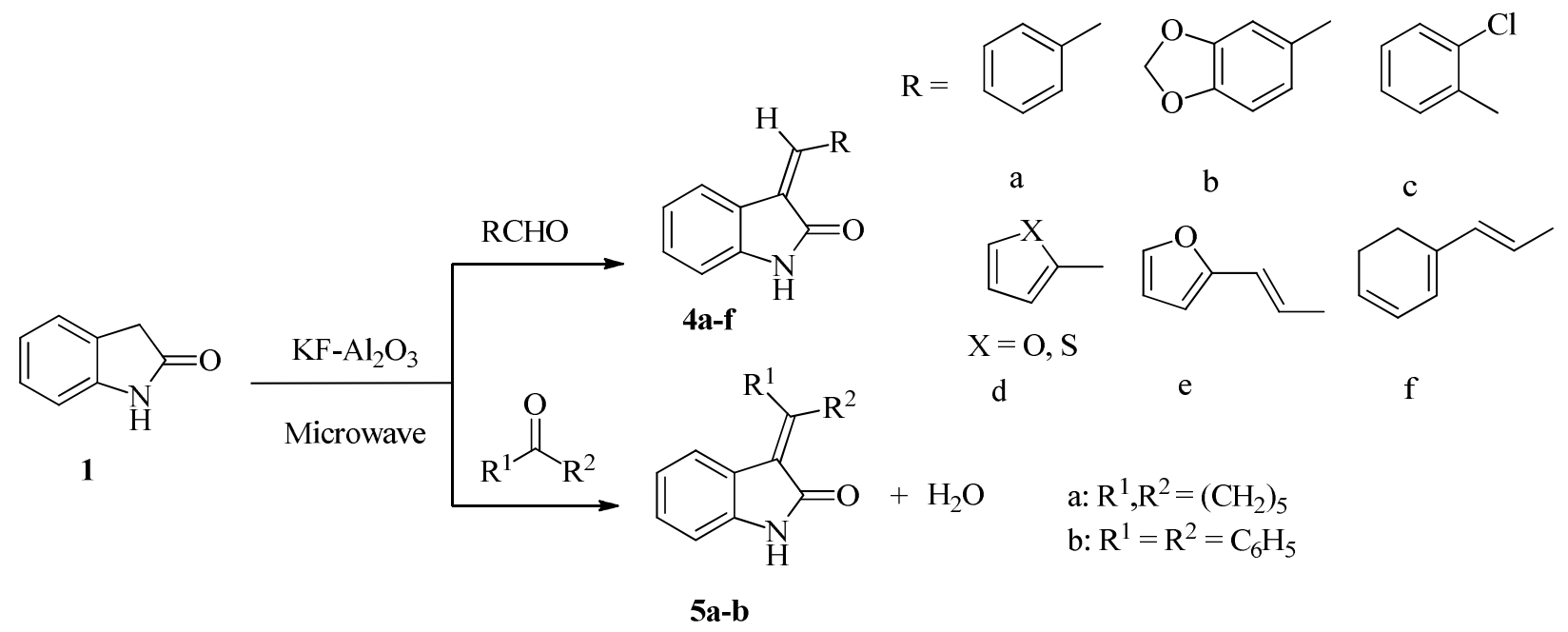

\section{Scheme 4}

In 2012, Mohammadi Ziarani and coworkers performed condensation reaction of oxindole 1 with benzaldehyde derivatives $\mathbf{2}$ in the presence of sulfonic acid functionalized nanoporous silica (SBA-Pr-SO ${ }_{3} \mathrm{H}$ ) under solvent-free condition to generate $E$-isomer of compound $\mathbf{3}$ (Scheme 5). ${ }^{19}$

In a related study, compounds $\mathbf{3}$ were synthesized by condensation of oxindole $\mathbf{1}$ with several aromatic aldehydes $\mathbf{2}$. Subsequent asymmetric 1,3-dipolar cycloaddition reaction was carried out by 


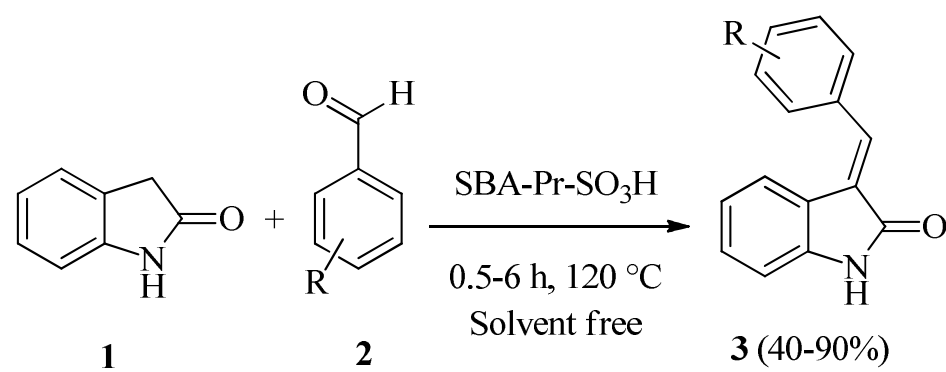

$\mathrm{R}=\mathrm{H}, 2-\mathrm{OMe}, 3-\mathrm{OMe}, 4-\mathrm{OMe}, 2,3-(\mathrm{OMe})_{2}, 4-\mathrm{OH}$, $4-\mathrm{NMe}_{2}, 4-\mathrm{Cl}, 2,3-\mathrm{Cl}_{2}, 3-\mathrm{NO}_{2}$

\section{Scheme 5}

heating the adduct product 3 with alkyl aldehydes 7 and $(5 R, 6 S)-5,6$-diphenylmorpholin-2-one $\mathbf{6}$ in the presence of a dehydrating agent. Compounds 8 , the major products of this reaction, were then treated with dimethylamine to afford amides $\mathbf{9}$ in good overall yields developed for the synthesis of final compounds 10. These compounds are potential inhibitors of the p53-MDM2 interaction $^{20}$ (Scheme 6).<smiles>O=CC1CC(=O)Nc2cc[R]#cc21</smiles>

1

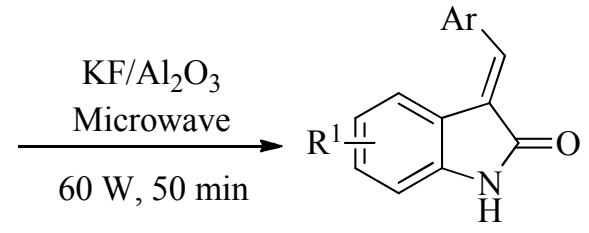

3

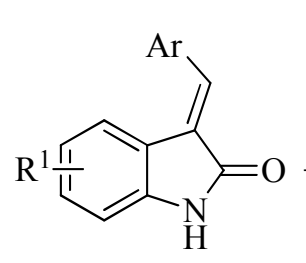

3<smiles></smiles>

6

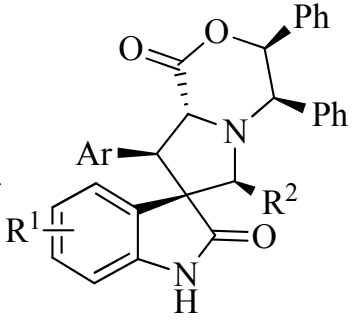

8

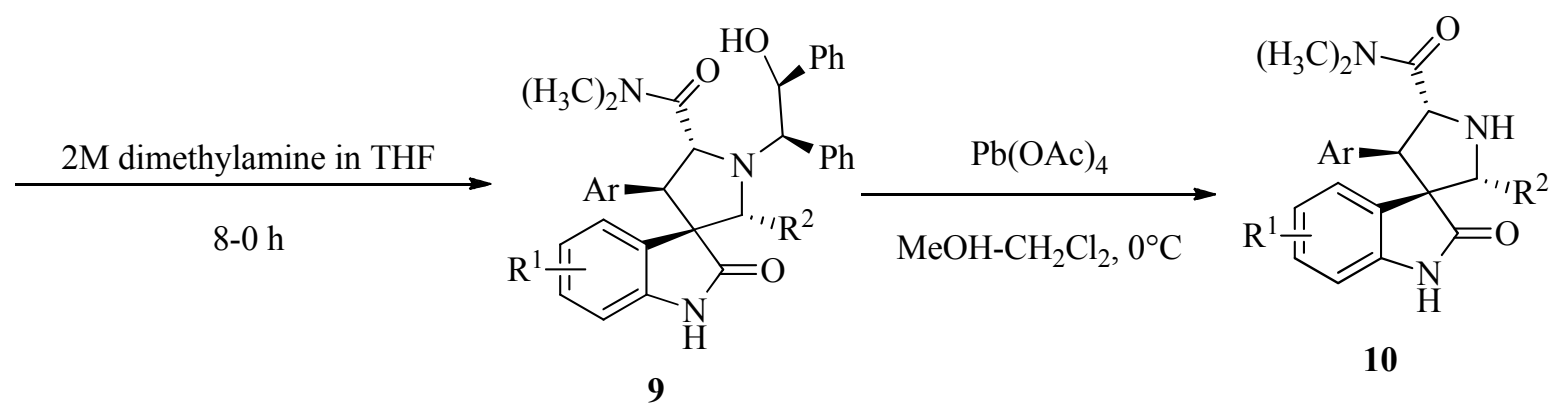

$\mathrm{Ar}=\mathrm{Ph}$, 2-pyridinyl, 3-thiophenyl, 3-OMe- $\mathrm{C}_{6} \mathrm{H}_{4}$

$\mathrm{R}^{1}=\mathrm{H}, 6-\mathrm{Cl}, 6-\mathrm{Br}, 6-\mathrm{F}, 6-\mathrm{CF}_{3}$

$\mathrm{R}^{2}=$ i-butyl, 2,2-dimethyl-propyl, 2,2-dimethyl-butyl, n-propyl

\section{Scheme 6}


Compound 12, resulted from the condensation of oxindole 1 with aldehyde 11 under microwave heating, was subjected to $N$-methylation and hydrogenation reaction to afford compound 13 in $95 \%$ yield. The following Mo-catalyzed asymmetric allylic alkylation reactions (AAA reactions) proceeded well and the allylated product $\mathbf{1 4}$ was isolated in $96 \%$ yield and $95 \%$ ee. Deprotection of the Boc group with trifluoroacetic acid (TFA) and dehydrative cyclization with titanium tetraisopropoxide then provided the dihydro-indolinoquinoline $\mathbf{1 5}$ as the final product (Scheme 7). ${ }^{21}$

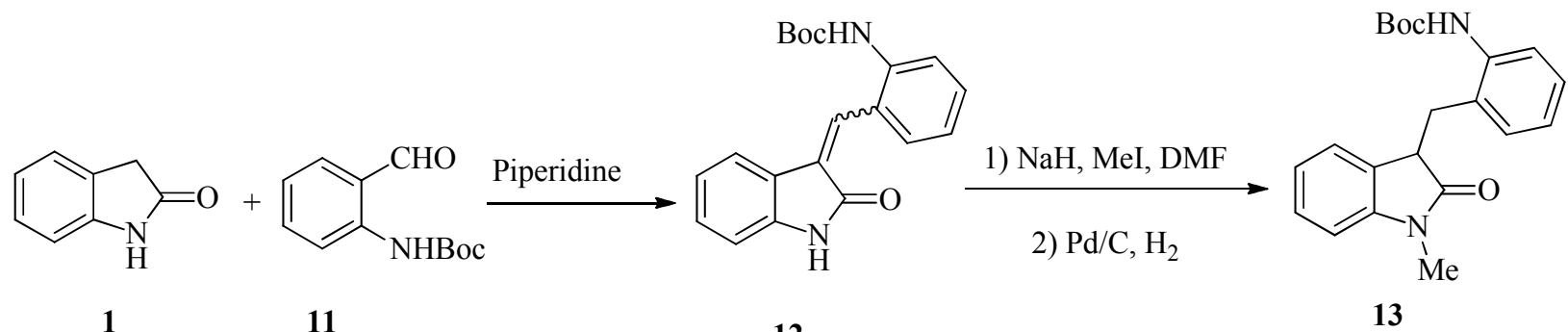

1

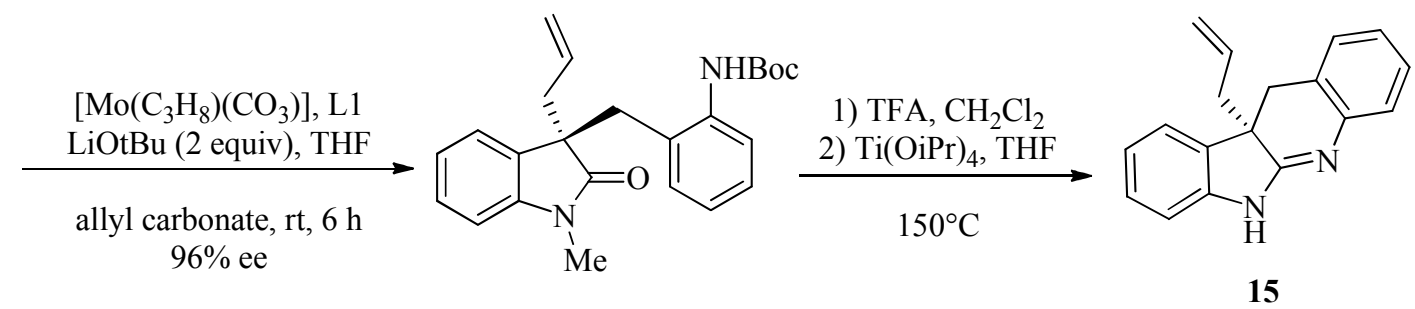

14

\section{Scheme 7}
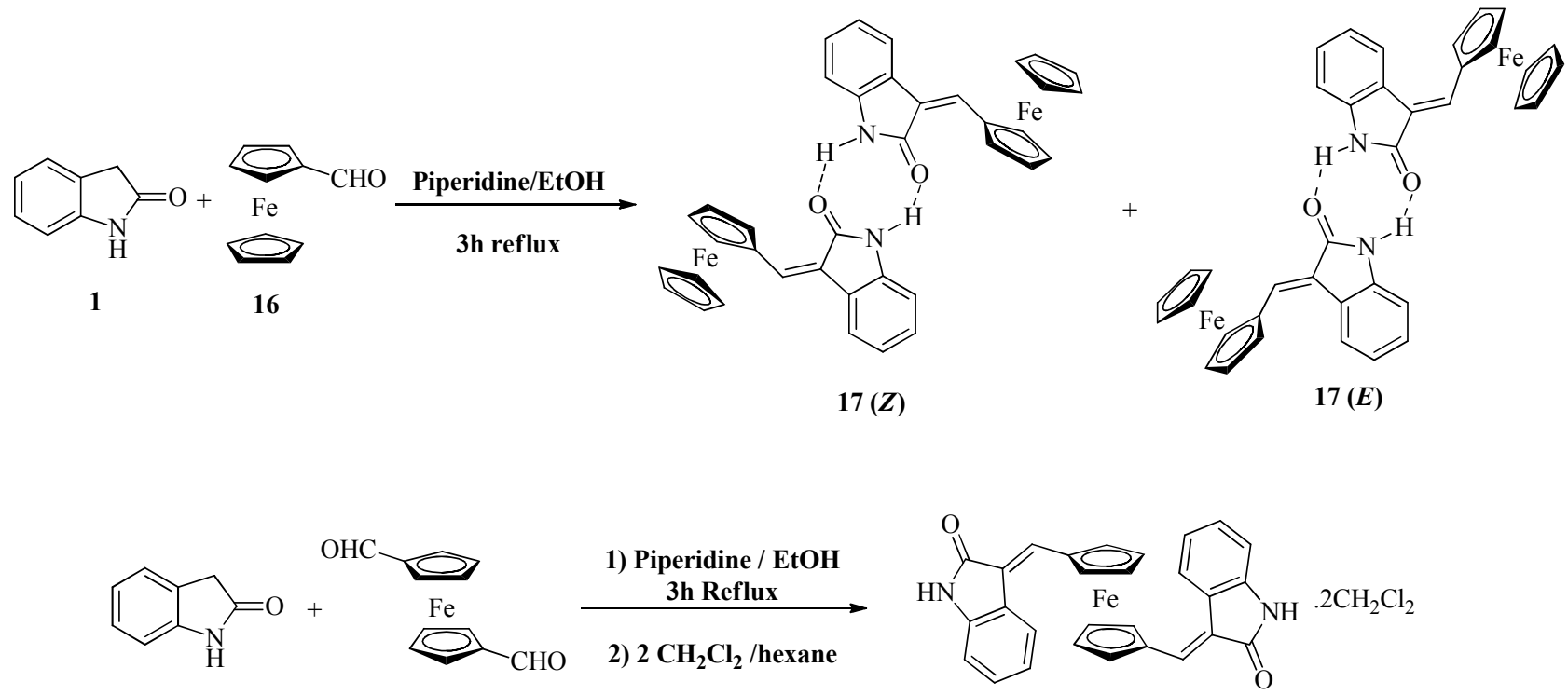

18

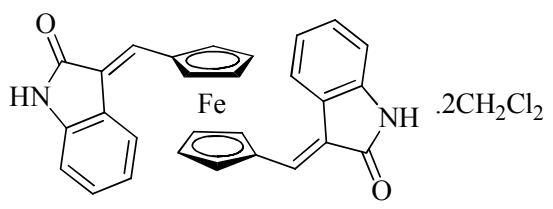

19

\section{Scheme 8}


Male and coworkers reported their finding in the synthesis of the isomeric ferrocenyl oxindoles, $(E)$ - and $(Z)$-3-(ferrocenylmethylidene)indolin-2-one 17, which are readily separated and have excellent anti-cancer properties. Oxindole 1 also undergoes a Knoevenagel condensation with

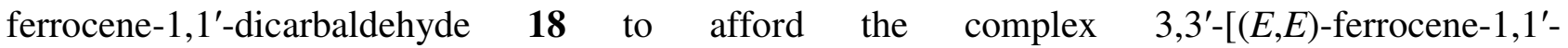
diyldimethylidyne]diindolin-2-one 19 (as bisdichloromethane solvate) (Scheme 8). ${ }^{22}$

Compound 21, with antiamnesic effects, has been synthesized by the condensing of oxindole $\mathbf{1}$ and 4-aminonicotinaldehyde $\mathbf{2 0}$ in methanol in the presence of piperidine as catalyst (Scheme 9). ${ }^{23}$

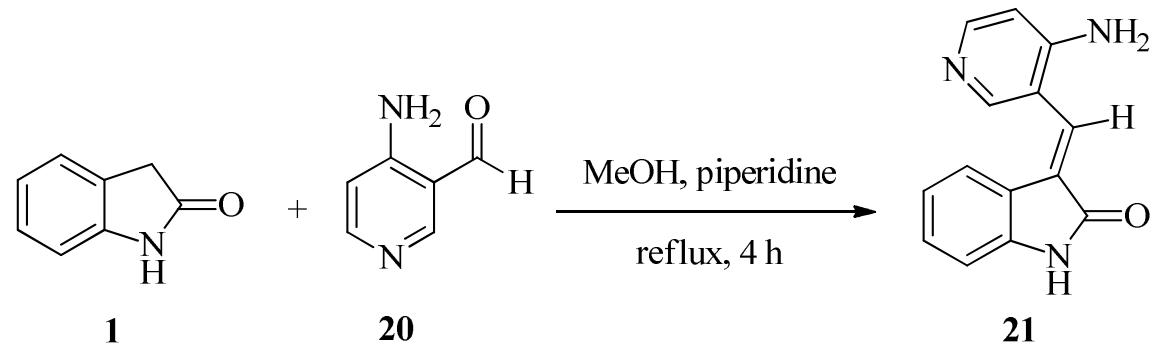

\section{Scheme 9}

Treatment of oxindole 1 with 4-(piperidin-1-yl)phenylacetone 22 in refluxing toluene in the presence of pyrrolidine provided the desired $(E)-3-[1-[4-(P i p e r i d i n-1-y l) p h e n y l]$ ethylidenyl $]$ indolin2-one 23 (Scheme 10). ${ }^{24}$

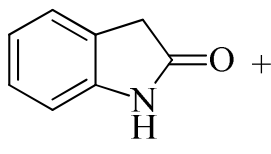

1

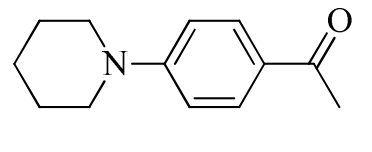

22

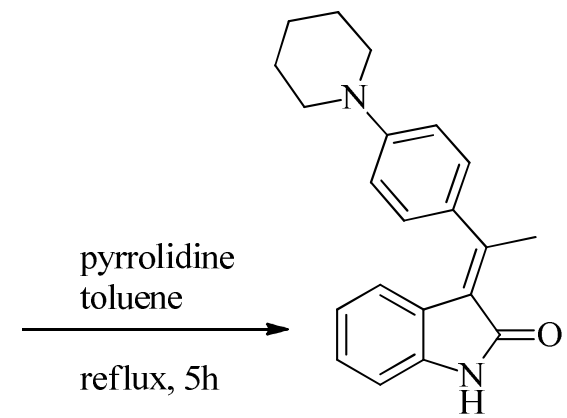

23

\section{Scheme 10}

2.1.2. Condensation reactions of oxindole with isatin derivatives. Danguuei Longhui Wan is a traditional Chinese recipe with a mixture of 11 herbal medicines for treatment of chronic myelocytic leukemia (CML). This powder contains a high level of the dark blue dye indigo, but its antileukaemic activity is attributed to the red-coloured isomer of indigo, indirubin. ${ }^{25}$ Indirubin, indigo and isoindigo are isomers; meisoindigo (1-methylisoindigo) and Natura ${ }^{\mathrm{TM}}$ (1- $\beta$-Dtriacetylxylopyranosylisoindigo) are isoindigo derivatives of which meisoindigo is a therapeutic agent used for the treatment of CML in China, while the anti-cancer agent activity of Natura ${ }^{\mathrm{TM}}$ is attributed to inhibition of several cyclin dependent kinases (CDKs) (Scheme 11). ${ }^{26}$ 
<smiles>O=C1/C(=C2\Nc3ccccc3C2=O)Nc2ccccc21</smiles>

Indigo<smiles>O=C1Nc2ccccc2/C1=C1/Nc2ccccc2C1=O</smiles>

Indirubin<smiles>O=C1Nc2ccccc2/C1=C1/C(=O)Nc2ccccc21</smiles>

Isoindigo<smiles>CN1C(=O)/C(=C2\C(=O)Nc3ccccc32)c2ccccc21</smiles>

Meisoindigo<smiles>CC(=O)OC1CC(OC(C)=O)C(OC(C)=O)N(C2C(=O)C(=C3C(=O)Nc4ccccc43)c3ccccc32)C1=O</smiles>

\section{Scheme 11}

The reaction of glycosyl-isatin derivatives $\mathbf{2 4}$ with oxindole $\mathbf{1}$ in an acidic medium has been reported by Moreau and coworkers. ${ }^{27}$ Deprotection of the hydroxyl groups of the glycosyl moiety was performed by reaction with boron tribromide to give compounds 26 (Scheme 12). In another study, Mohammadi Ziarani and coworkers investigated the synthesis of isoindigo derivatives through the condensation of oxindole with isatin derivatives using $\mathrm{SBA}-\mathrm{Pr}-\mathrm{SO}_{3} \mathrm{H}$ with pore size of $6 \mathrm{~nm}$ as a heterogeneous acid catalyst under solvent-free conditions (Scheme 13). ${ }^{28}$ The synthesized compounds were screened for their antimicrobial activities.

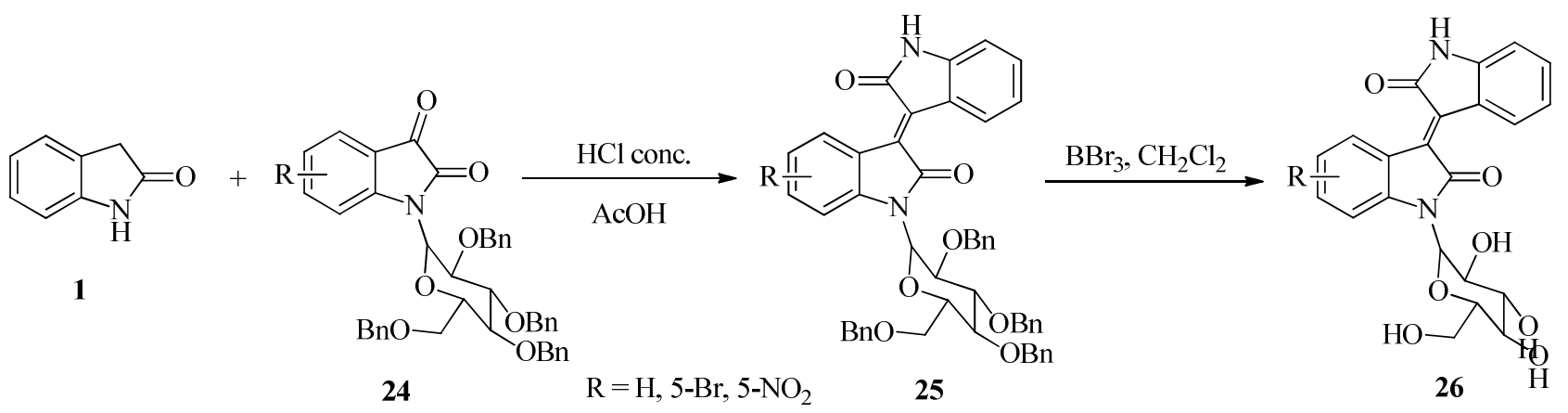

\section{Scheme 12}

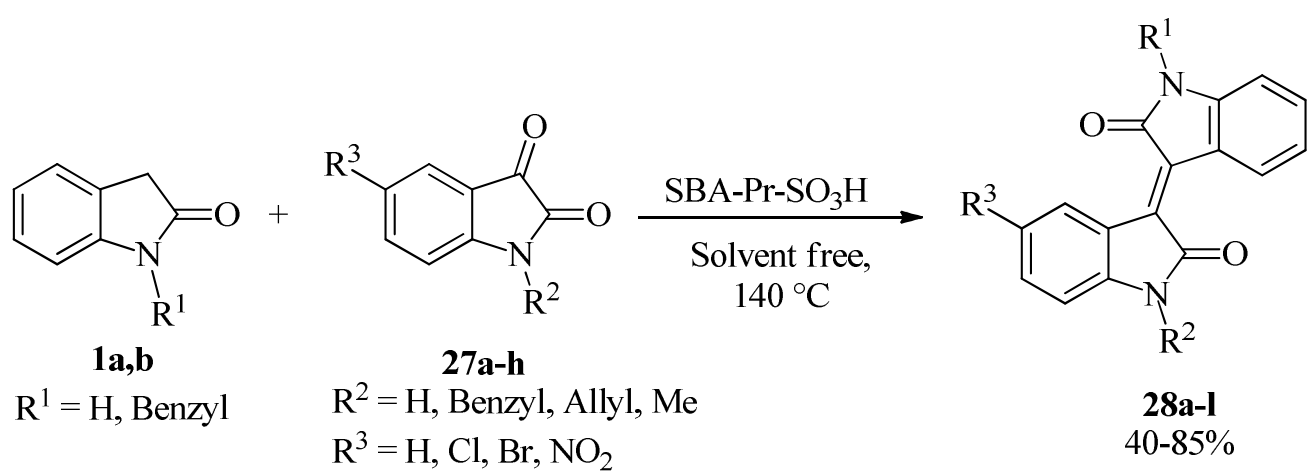

\section{Scheme 13}


In a similar approach, synthesis of acetylated glycosyl-isoindigo derivatives $\mathbf{3 0}$ by condensation of acetylated glycosyl-isatins $\mathbf{2 9}$ with oxindole $\mathbf{1}$ in the presence of $p$-toluenesulfonic acid ( $p$ TSA) has been reported (Scheme 14). ${ }^{29}$

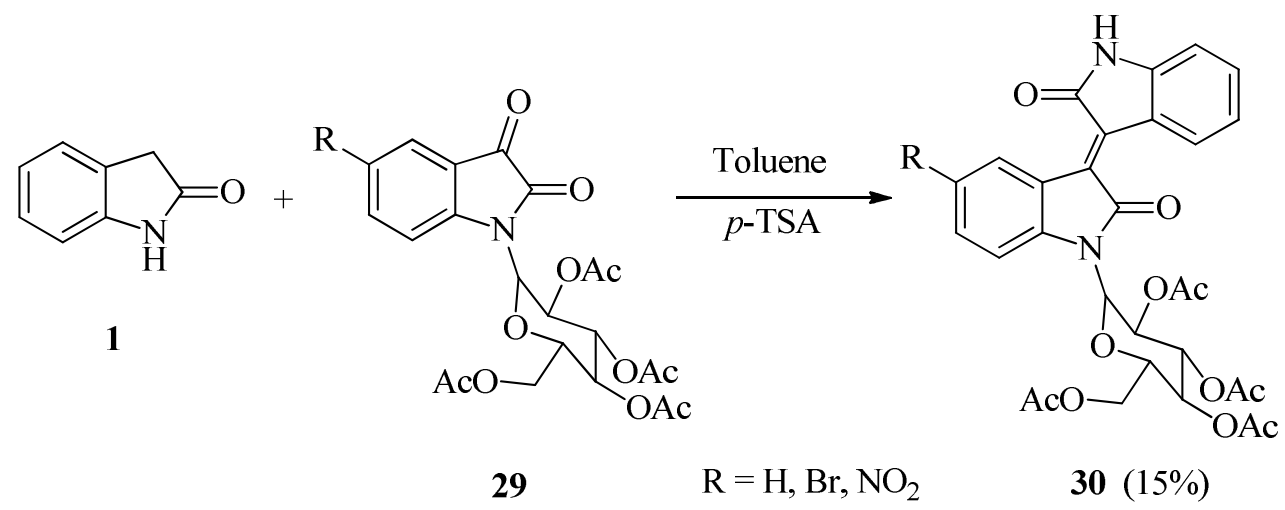

\section{Scheme 14}
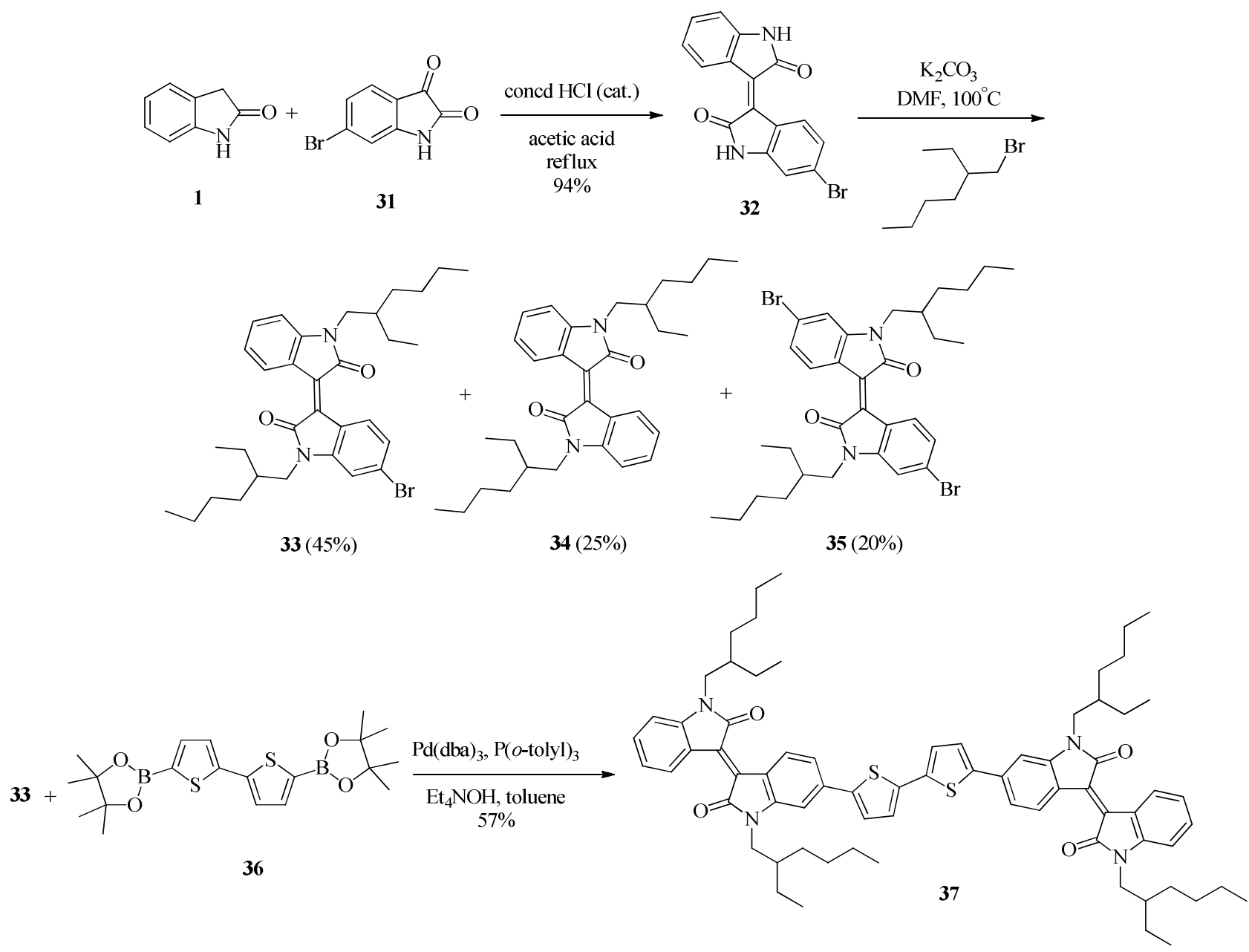

Scheme 15 
Acid-catalyzed condensation and dehydration of oxindole 1 and 6-bromoisatin 31 to afford 6bromoisoindigo 32 has been reported. Interestingly, subsequent $N$-alkylation of compound 32 using branched alkyl bromide resulted in the formation of three products $\mathbf{3 3}, \mathbf{3 4}$, and $\mathbf{3 5}$. With $\mathbf{3 3}$ in hand, isoindigo-based acceptor-donor-acceptor (ADA) oligothiophene $\mathbf{3 7}$ was successfully obtained by incorporating electron rich bithiophene units 36 via Suzuki coupling reaction (Scheme 15). ${ }^{30}$ In this communication, the isoindigo unit was used as an electron acceptor to form ADA isoindigo-based oligothiophenes in conjunction with bithiophene as an electron donor.

The [3+2]-cycloaddition reaction of isoindigo derivatives $\mathbf{2 8}$, obtained from oxindole $\mathbf{1}$ and isatin derivatives 27, with azomethine ylides generated in situ from sarcosine $\mathbf{3 8}$ and paraformaldehyde, afforded products 39 in high yields and in a diastereoselective manner (Scheme 16). ${ }^{31}$

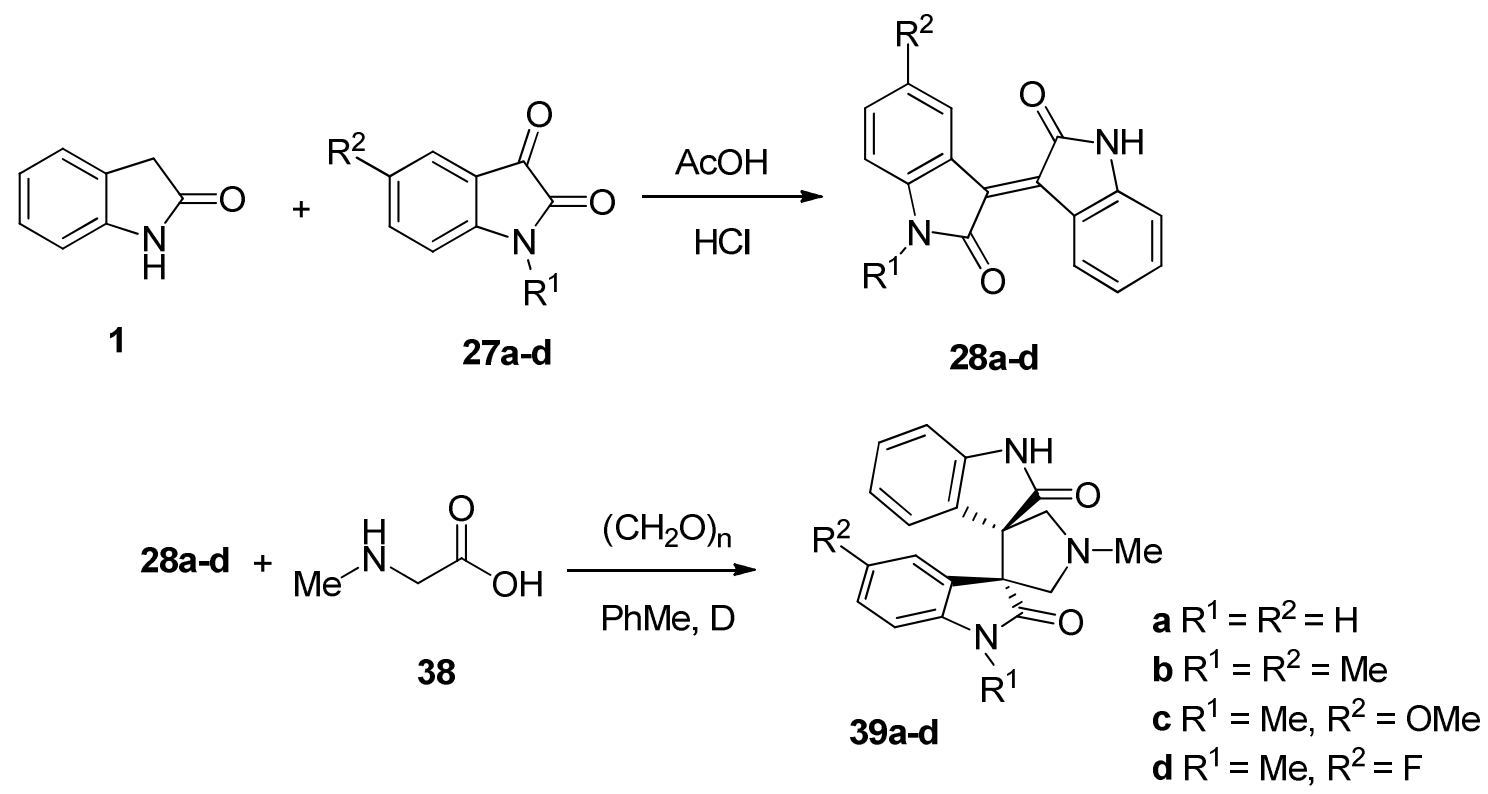

\section{Scheme 16}

2.1.3. Condensation reactions with ninhydrin. It was reported that the Knoevenagel condensation reaction of ninhydrin $\mathbf{4 0}$ with oxindole $\mathbf{1}$ in the presence of montmorillonite K10 clay afforded the adduct product $\mathbf{4 1}$ after 30 minutes (Scheme 17). ${ }^{32}$<smiles>O=C1Cc2ccccc2N1</smiles>

1<smiles>O=C1c2ccccc2C(=O)C1(O)O</smiles>

40
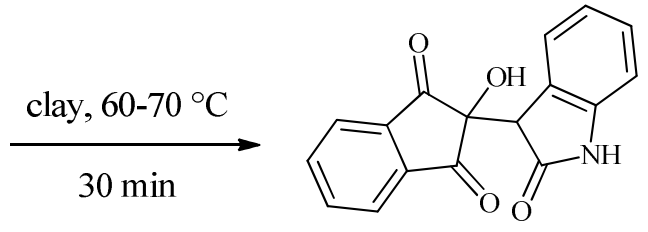

41

\section{Scheme 17}

2.1.4. Condensation reactions with carbaldehydes. The reaction of various substituted oxindoles 1 with 3,5-dimethylpyrrol-2-carbaldehyde derivatives 42 under Knoevenagel condensations 
afforded an array of nitro-substituted derivatives of Semaxinib 43 (SU5416) in good yields (Scheme 18). ${ }^{33}$ Semaxinib is a potent inhibitor of signaling activity of the Receptor Tyrosine Kinases (RTKs) for the vascular endothelial growth factor (VEGF).

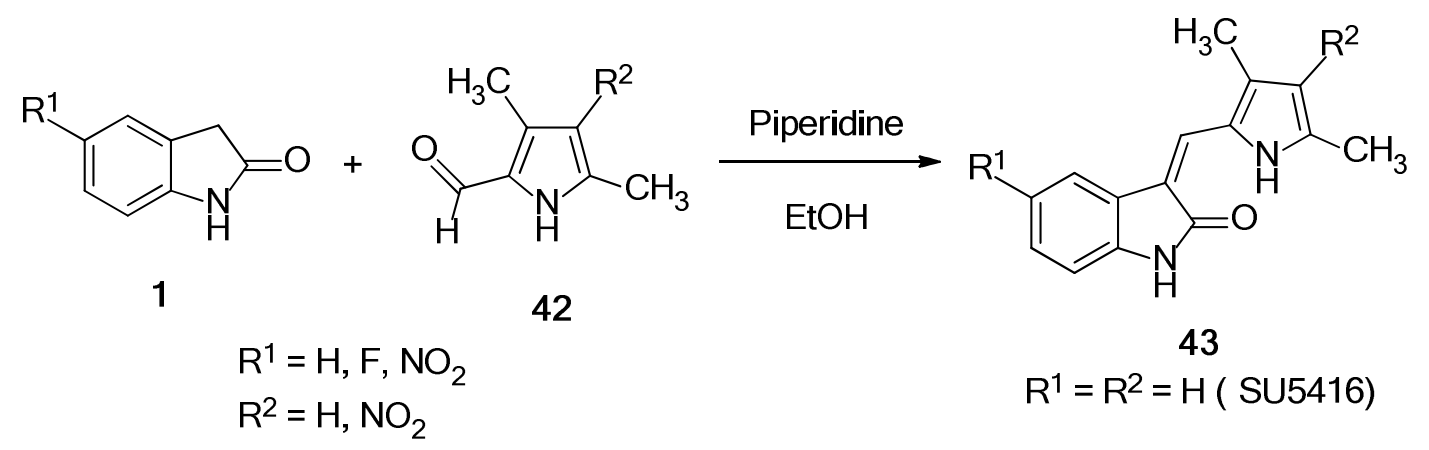

\section{Scheme 18}

The synthesis and anti-tumor activity of new (E)-3-(2-chloro-3-indolylmethylene)-1,3dihydroindol-2-ones $\mathbf{4 5}$ via condensation of 2-chloro-5-methoxy-1,6-dimethylindole-3carbaldehyde $\mathbf{4 4}$ with oxindole derivatives $\mathbf{1}$ have been reported (Scheme 19). ${ }^{34}$ All the compounds were potent growth inhibitors.

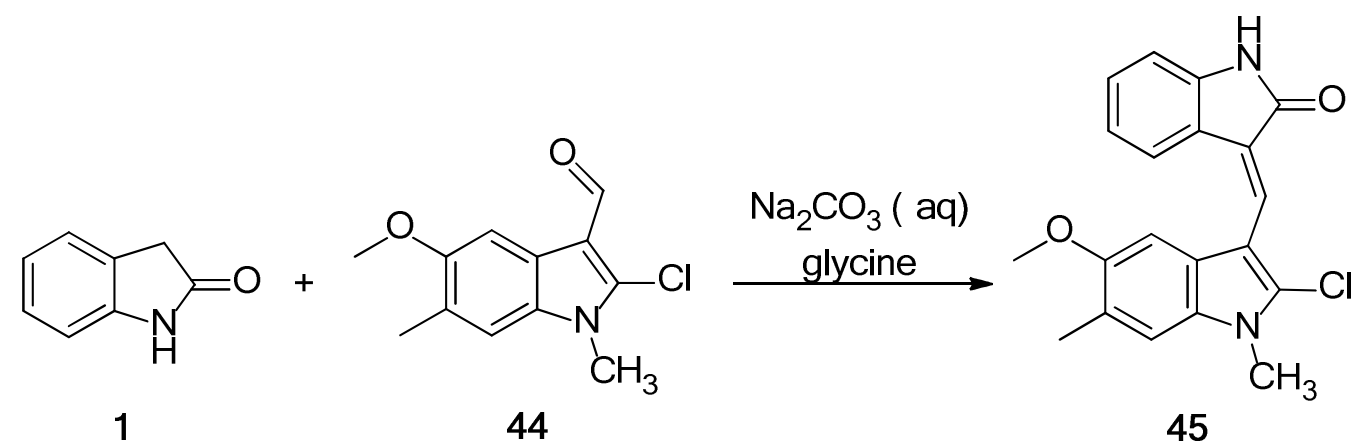

\section{Scheme 19}

A series of 3-substituted oxindoles $\mathbf{4 7}$ containing propionic acid functionality attached to the pyrrole ring at the $\mathrm{C}-3$ position of the core has been synthesized by the reaction of oxindoles $\mathbf{1}$ with 4-carboxyethyl-3-methylpyrrol-2-carboxaldehyde derivatives 46 (Scheme 20). The products have been identified as catalytic inhibitors of the vascular endothelial growth factor (VEGF), fibroblast growth factor (FGF), and platelet-derived growth factor (PDGF) RTKs. Since these RTKs have crucial roles in many disease processes, they can be used for the treatment of human diseases including cancers, inflammatory diseases, cardiovascular diseases and fibrotic diseases of the lung, liver, and kidney. ${ }^{35}$ 


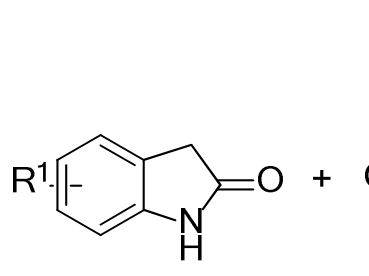

1

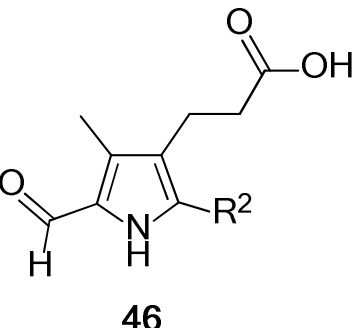

46
1) Piperidine

$\mathrm{EtOH}$

reflux

2) $\mathrm{HCl}(\mathrm{aq})$

$$
\begin{aligned}
\mathrm{R}^{1}= & \mathrm{H}, 5-\mathrm{CO}_{2} \mathrm{H}, 5-\mathrm{SO}_{2} \mathrm{NH}_{2}, 6-\mathrm{OMe}, 6-\mathrm{Ph}, \\
& \text { 6-( 3-MeOC } \left.{ }_{6} \mathrm{H}_{4}\right), 6-\left(2-\mathrm{MeOC}_{6} \mathrm{H}_{4}\right), 6-\left(4-\mathrm{MeOC}_{6} \mathrm{H}_{4}\right) \\
\mathrm{R}^{2}= & \mathrm{H}, \mathrm{Me}
\end{aligned}
$$

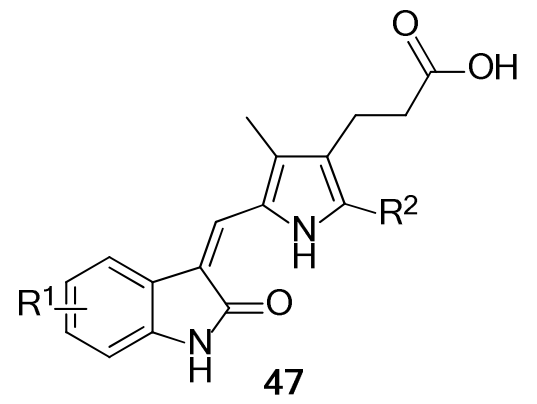

$\mathrm{R}^{2}=\mathrm{H}(4 \mathrm{~h})$

$\mathrm{R}^{2}=\mathrm{Me}$ ( overnight)

\section{Scheme 20}

Shih and Yeh reported the syntheses of sydnonyl-substituted oxindole derivatives 49 by the modified Knoevenagel condensation of 3-aryl-4-formyl-sydnones 48 with oxindole and 5chlorooxindole (Scheme 21). ${ }^{36}$<smiles>[R]c1ccc2c(c1)CC(=O)N2</smiles>

1<smiles></smiles>

48<smiles>[R]c1ccc2c(c1)/C(=C/c1c(O)on[n+]1[Al-])C(=O)N2</smiles>

49

$$
\begin{aligned}
& \mathrm{Ar}=\mathrm{C}_{6} \mathrm{H}_{5}, p-\mathrm{MeC}_{6} \mathrm{H}_{4}, p-\mathrm{MeOC}_{6} \mathrm{H}_{4}, p-\mathrm{EtOC}_{6} \mathrm{H}_{4} \\
& \mathrm{R}=\mathrm{H}, \mathrm{Cl}
\end{aligned}
$$

\section{Scheme 21}

2.1.5. Condensation reactions with esters and nitriles. Oxindole as a carbonyl compound in reaction with methoxyacetonitrile $\mathbf{5 0}$ in the presence of rhenium heptahydride complex as an excellent catalyst, leads to selective formation of the $Z$ isomer of 3-(1'-amino-2'methoxy)ethylindene indole-2-one $\mathbf{5 1}$ in $76 \%$ yield (Scheme 22). ${ }^{37}$

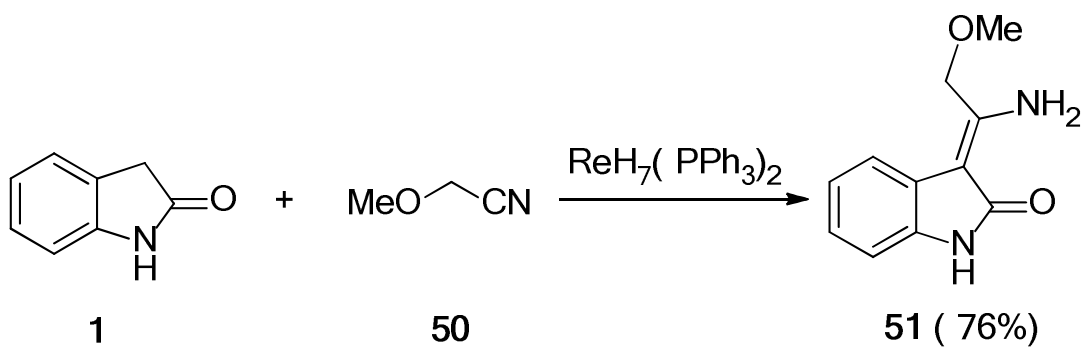

\section{Scheme 22}


The condensation of oxindole 1 with acetal esters 52 and cyclic $\beta$-ketoesters 55a-c yielded the 3 -acyloxindoles 53 and 56a-c, respectively. Subsequent cyclization of these compounds to the 2and 3-substituted pyrano[2,3-b]indolones 54 and 57a-c has been developed (Scheme 23). ${ }^{38}$ Later, Engqvist and Bergman indicated that when oxindole is condensed with methyl anthranilate under basic conditions angular products are obtained after a nucleophilic attack of oxindole followed by recyclization. ${ }^{39}$

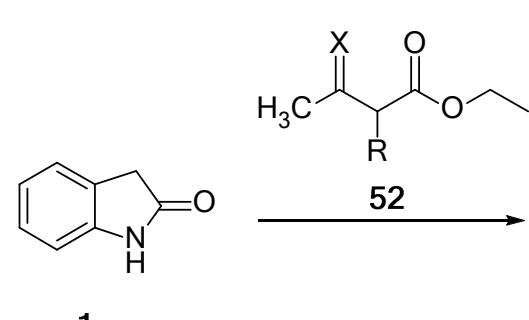

1<smiles>[X]C(C)C([R])C(=O)C1C(=O)Nc2ccccc21</smiles>

53

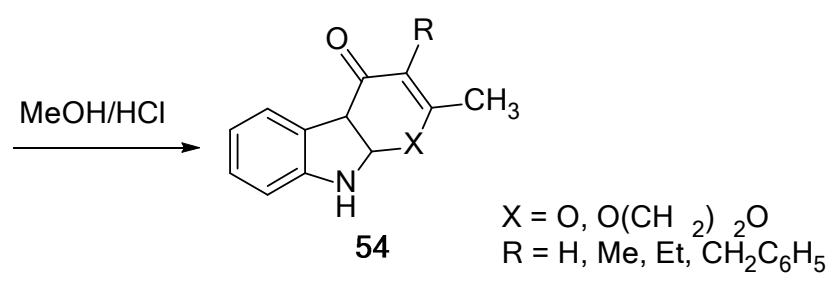<smiles>CCOC(=O)C1CCCC1=O</smiles><smiles>O=C1CCCC1C(=O)C1C(=O)Nc2ccccc21</smiles>

$\mathrm{MeOH} / \mathrm{HCl}$<smiles>O=c1c2c(oc3[nH]c4ccccc4c13)CCC2</smiles>

$56 a$ $57 a$<smiles>O=C1Cc2ccccc2N1</smiles>

1

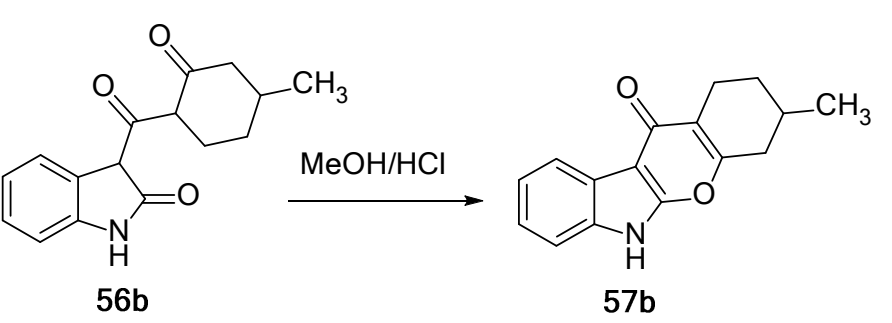

${ }_{55 \mathrm{c}}^{\mathrm{EtO} \mathrm{C}_{2} \mathrm{C}}$

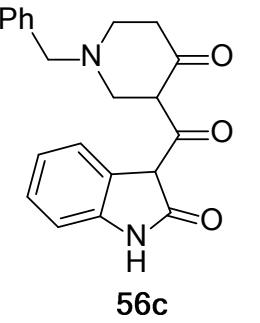

$\mathrm{MeOH} / \mathrm{HCl}$

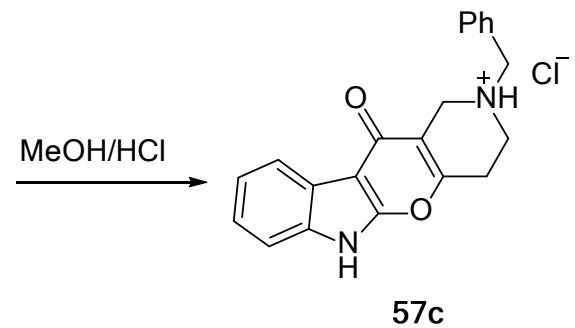

\section{Scheme 23}

In another study, oxindole 1 was condensed with ethyl esters 58a-i to give the 3-[(1-hydroxy-2substituted)ethylidene]indol-2(3H)-ones 59a-i. The corresponding chloro-derivatives $\mathbf{6 0}$ were prepared by reaction with $\mathrm{Ph}_{3} \mathrm{P} / \mathrm{CCl}_{4}$ in anhydrous THF. It was observed that compound 59i did not afford the corresponding chloro-derivative, instead, the 3-oxazolylindol-2(3H)-one 61 was obtained, whose structure was confirmed by reaction with ethyl chloroformate and triethylamine (TEA), to 
give 1-ethoxycarbonyl-2-ethoxycarbonyloxy derivative 62. On the assumption that the acylation of the indolic nitrogen does not alter the reactivity of the chloro-compounds $\mathbf{6 0}$ with the TEA, compound 63 was prepared from 60a. The treatment of a dichloromethane solution of 63 with TEA afforded a reaction mixture from which a dimeric crystalline compound $\mathbf{6 4}$ was isolated (Scheme $24) .^{40,41}$

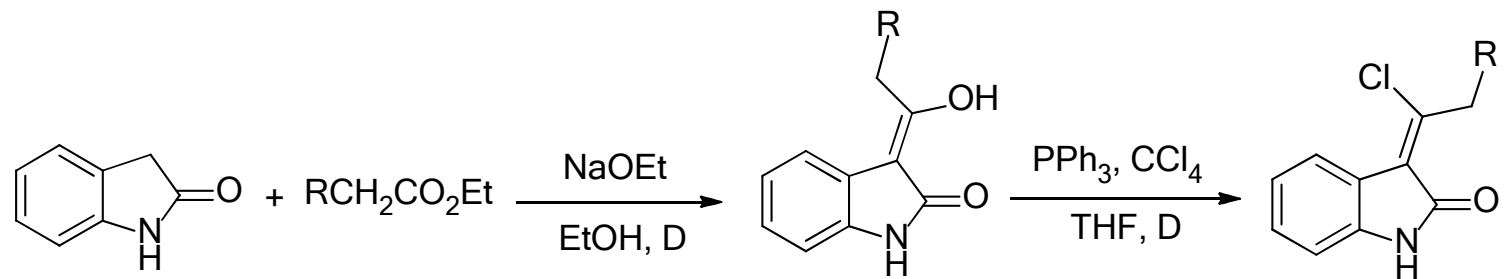

1

$58 \mathrm{a}-\mathrm{i}$

$59 a-i$

$60 \mathrm{a}-\mathrm{h}$

$\mathrm{R}=\mathrm{Ph}, \mathrm{H}, \mathrm{Me}, \mathrm{OMe}, \mathrm{CO}_{2} \mathrm{Et}, \mathrm{SMe}$,

2-thienyl, $\mathrm{CH}_{2} \mathrm{CO}_{2} \mathrm{Et}$, NHCOMe<smiles>CCOC(=O)/C=C\Cn1c(C(=O)OCC)c(-c2cnc(C)o2)c2ccccc21</smiles>

$59 i$

61

62

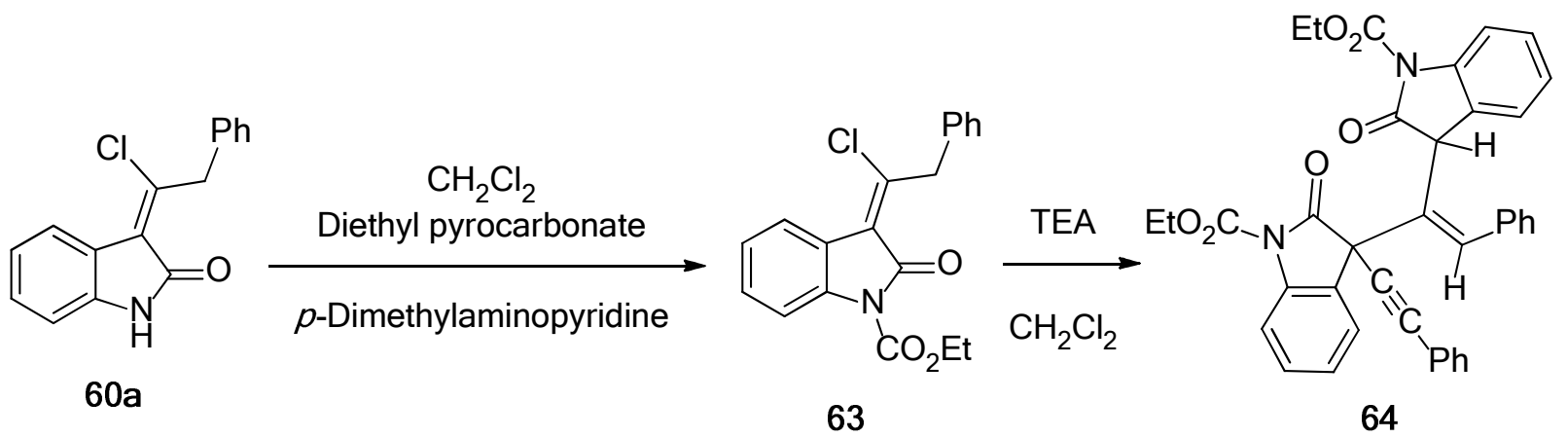

\section{Scheme 24}

Spirotryprostatin B 74, which has recently served as the blueprint for a library of cellular probes, has been synthesized in eight steps. The synthetic route starting from Cbz-proline $\mathbf{6 5}$ and dimethyl aminomalonate hydrochloride 66 resulted in the formation of known diketopiperazine 67 which was transesterified to prenyl ester 68 by Otera's catalyst. In a one-pot reaction, oxindole 69 was activated as its vinyl tosylate and reacted with the lithium salt of $\mathbf{6 8}$. With the key substrate in hand, compound 70 was subjected to palladium catalyst and converted to compounds $\mathbf{7 1}$ and 72. To functionalize the phenyl chain, 71 was first treated with PhSeOAc (prepared in situ) and then the selenide was oxidized and eliminated with $\mathrm{H}_{2} \mathrm{O}_{2}$, giving the allylic acetate 73. For the final 
cyclization, the use of aluminium amide, generated in situ by the treatment of $\mathbf{7 3}$ with trimethylaluminium, does succeed to give spirotryprostatin B $\mathbf{7 4}$ (Scheme 25). ${ }^{42}$
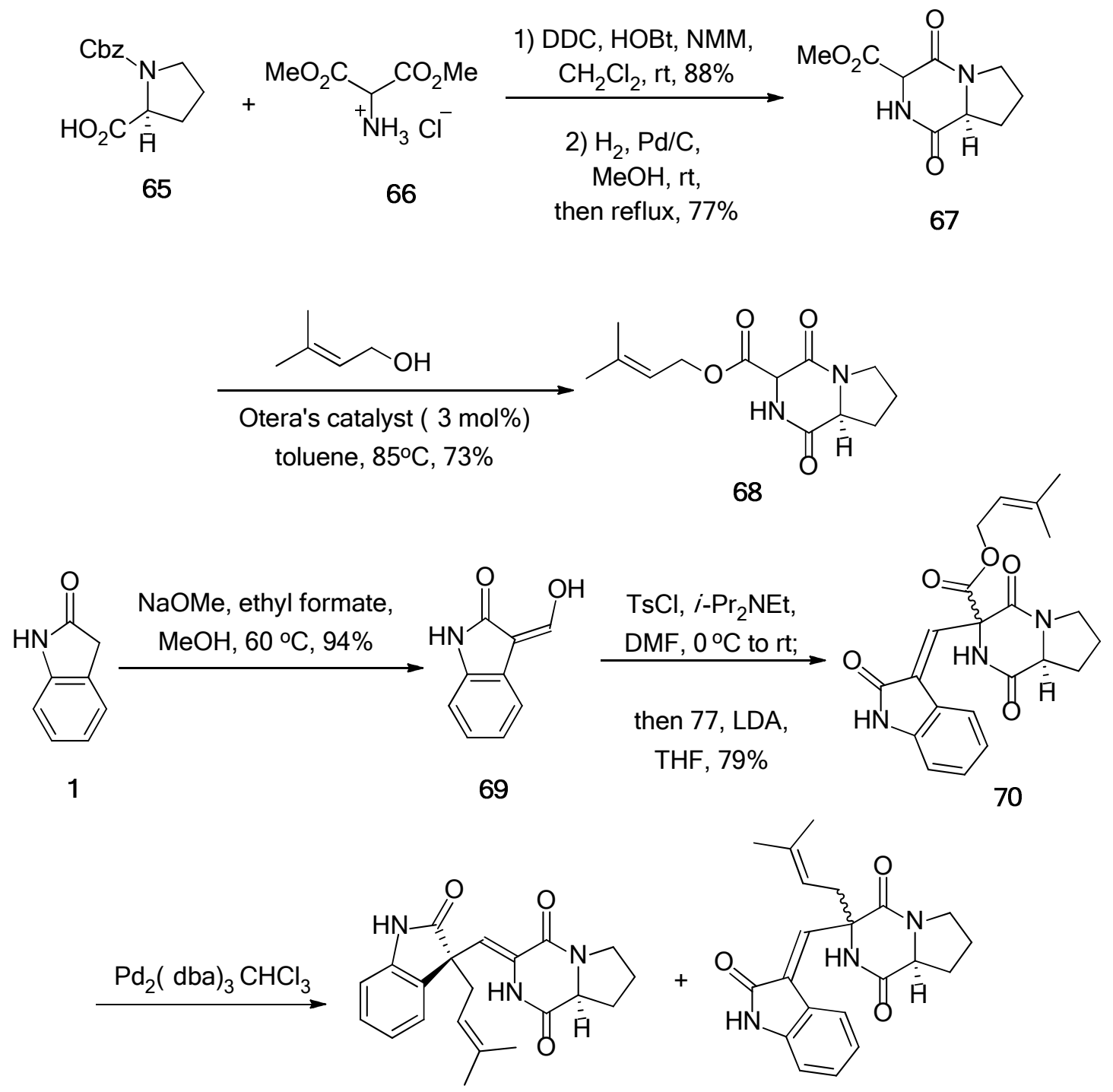<smiles>[Z4]C(C)=C[C@H]1N2C(=O)[C@@H]3CCCN3C(=O)C2=C[C@]12C(=O)Nc1ccccc12</smiles>

\section{Scheme 25}




\subsection{Reaction with halogenated compounds}

Kende and Hodges converted oxindole 1 to its dianion 75 by treatment with $n$-BuLi and tetramethylethylenediamine (TMEDA). Using the enhanced and regiospecific reactivity of the oxindole dianion, alkylations with a number of common electrophiles such as $n$-alkyl iodides resulted in useful transformations leading to compounds $\mathbf{7 6}$ and 3,3-disubstituted oxindoles $\mathbf{7 8}$ (Scheme 26). ${ }^{43}$ It is noteworthy that under these conditions no $N$-alkylation or $O$-alkylation was observed.

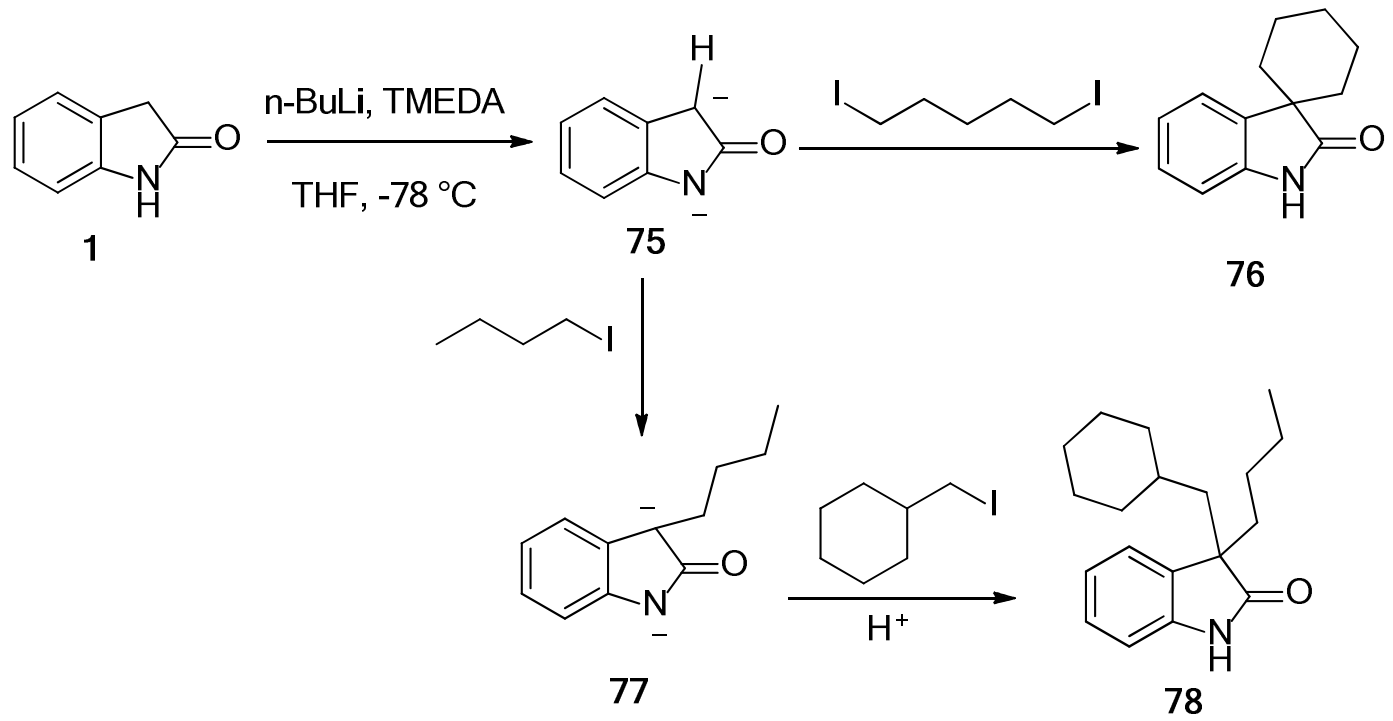

\section{Scheme 26}

Alkylation of the dianion of oxindole 75 with 3-(4-methoxyphenyl)propyl iodide following the previous procedure ${ }^{43}$ gave $41 \%$ yield of the C-3 monoalkylation product $\mathbf{7 9}$ which was converted to compound 80 using $\mathrm{K}_{3} \mathrm{Fe}(\mathrm{CN})_{6}$ in dilute $\mathrm{KOH}$. Compound 80 then rearranged to afford the crystalline phenol 81 in $91 \%$ yield (Scheme 27).<smiles>O=C1Nc2ccccc2C1CCCc1ccc(O)cc1</smiles>

79

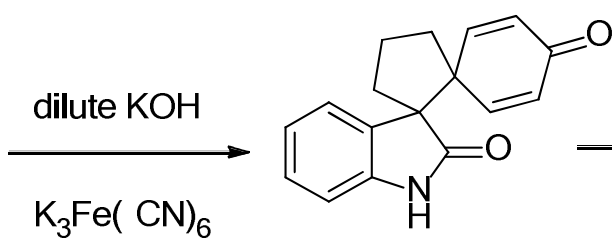

80<smiles>O=C1Nc2ccccc2C12CCCc1ccc(O)cc12</smiles>

81

\section{Scheme 27}


In another study, the dianion of oxindole was alkylated with the 6-iodo-2-hexyne according to the procedure of Kende. ${ }^{43}$ Subsequent formation of the dianion of the alkylated oxindole $\mathbf{8 2}$ and treatment with $\mathrm{N}$-Bromosuccinimide NBS at low temperature led to the formation of the 3-alkyl-3bromoindolin-2-one $\mathbf{8 3}$. Treatment of the alkyne $\mathbf{8 3}$ with cesium carbonate resulted in the formation of quinoline 86 in good yield (Scheme 28). ${ }^{45}$ This transformation presumably occurs via cycloaddition of the tethered alkyne with the intermediate oxindole $\mathbf{8 4}$ to provide a strained bridged bicyclic lactam $\mathbf{8 5}$. The lactam then undergoes a retrocheletropic reaction in situ to afford the final product 86.

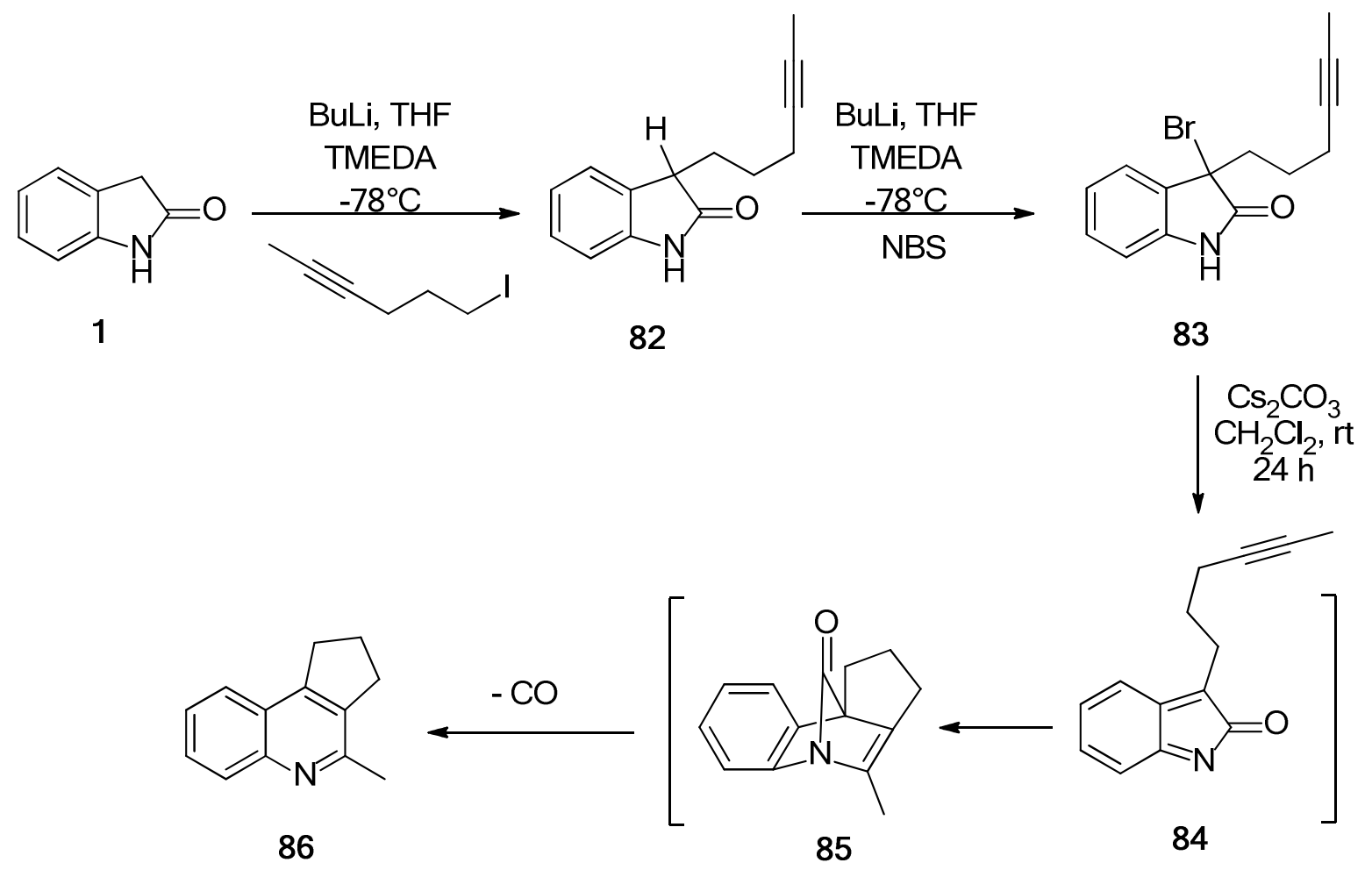

\section{Scheme 28}

Deprotonation of oxindole 1 with $\mathrm{NaH}$ followed by addition of 2,4-dichloropyrimidine and subsequent amination with various anilines led to the formation of compounds 87 which were screened for their inhibitory activity against transforming growth factor- $\beta$-activating kinase 1 (TAK1) (Scheme 29). ${ }^{46}$

Bergman and Romero published a study on the reactions of oxindoles $\mathbf{1}$ with thionyl chloride to give the isolable 3-sulfinatooxindoles $\mathbf{8 8}$. Refluxing $\mathbf{8 8}$ in acetonitrile resulted in the formation of isoindigo 90 while in reaction with 2,3-dimethylbutadiene a colorless cycloadduct 89 was synthesized (Scheme 30). ${ }^{47}$ 


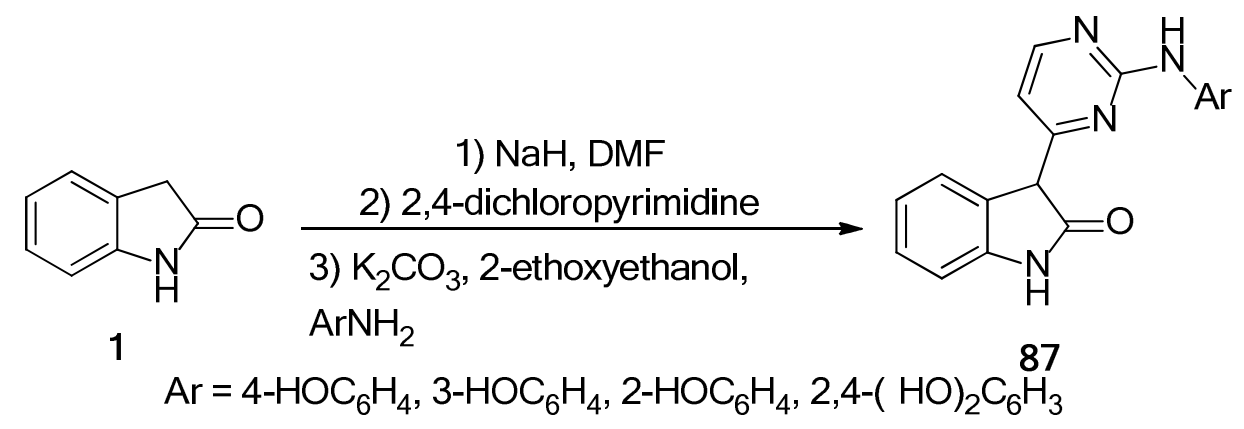

\section{Scheme 29}

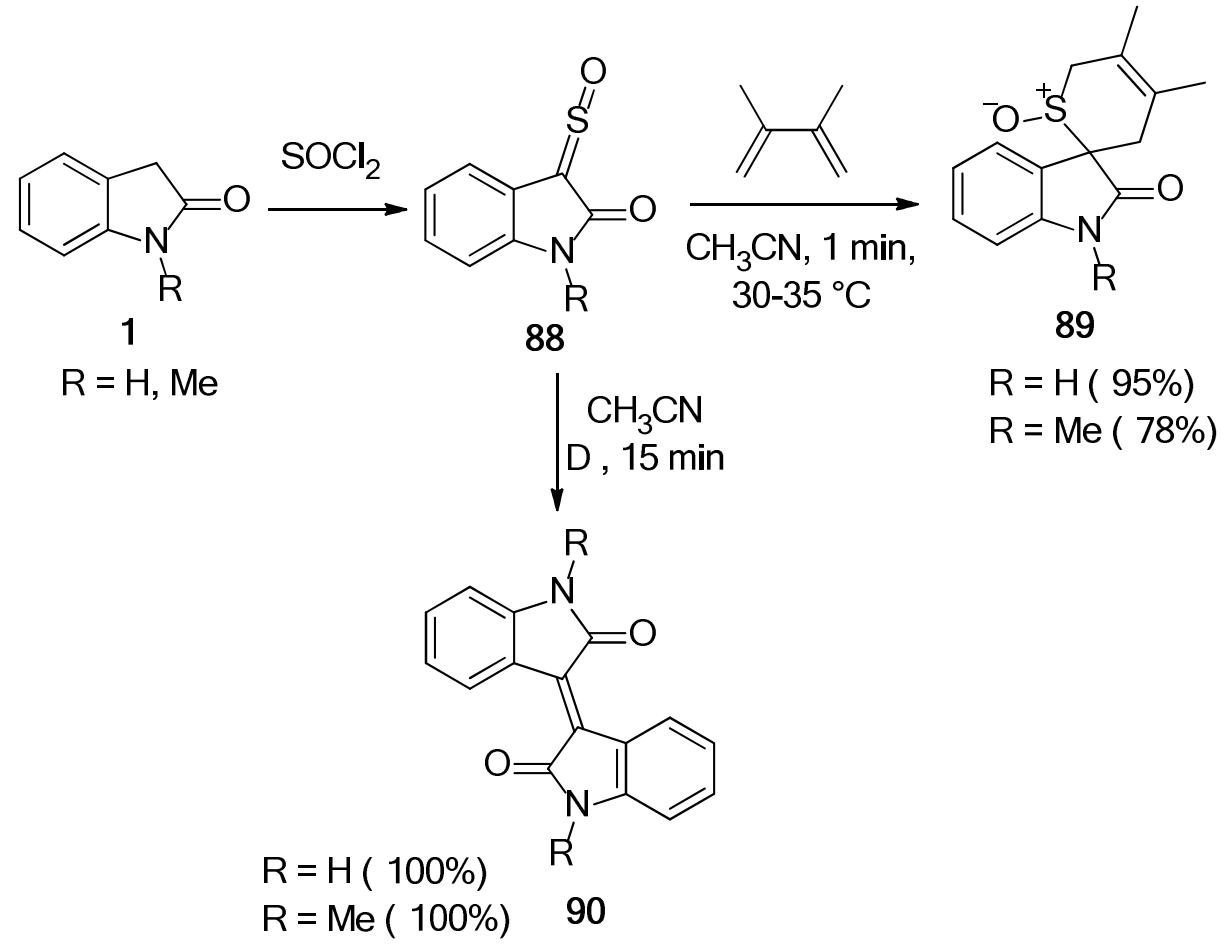

\section{Scheme 30}

In a six-step synthetic route, compound 95, a rotationally constrained analogue of 91, was prepared. Starting from the reaction of oxindole 1 with sodium hexamethyldisilazide (NaHMDS) in THF, and following alkylation with $N$-methylbis-(2-chloroethyl)amine, the spirocyclic oxindole 92 was obtained. Deprotonation with sodium hydride in DMF followed by alkylation with methyl bromoacetate inserted the acetic acid side chain in compound 93. Then, the $N$-methyl group in 93 could be replaced with a Boc group via a three step procedure, and finally saponification of the methyl ester resulted in a 74\% yield of the desired Boc protected amino acid 95 (Scheme 31). ${ }^{48}$ 
<smiles></smiles>

91<smiles>O=C1Cc2ccccc2N1</smiles>

1

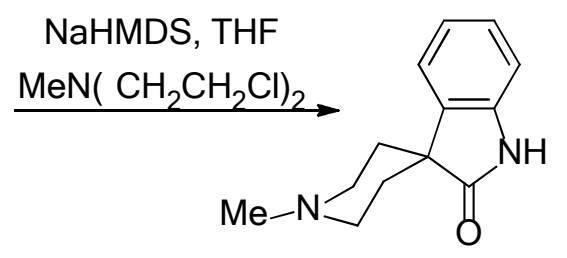

92

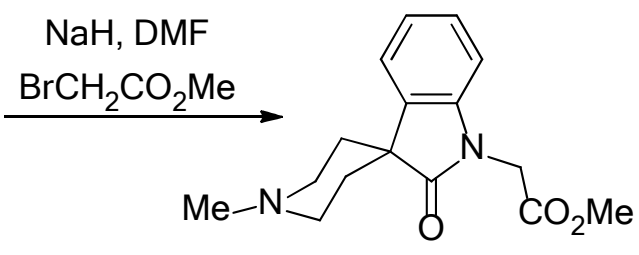

93
1) $\mathrm{ClCO}_{2} \mathrm{CH}_{2} \mathrm{CCl}_{3}$, toluene
2) $\mathrm{Zn}, \mathrm{HOAC}$

3) $(\mathrm{Boc})_{2} \mathrm{O}$, dioxane

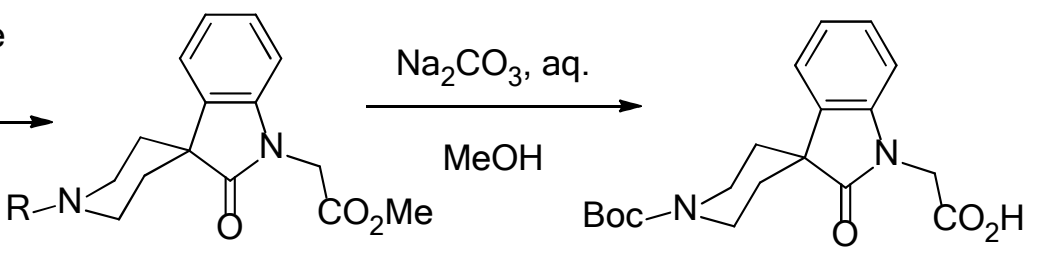

94a R= $\mathrm{CO}_{2} \mathrm{CH}_{2} \mathrm{CCl}_{3}$

94b R=H

94c $\mathrm{R}=\mathrm{Boc}$

\section{Scheme 31}

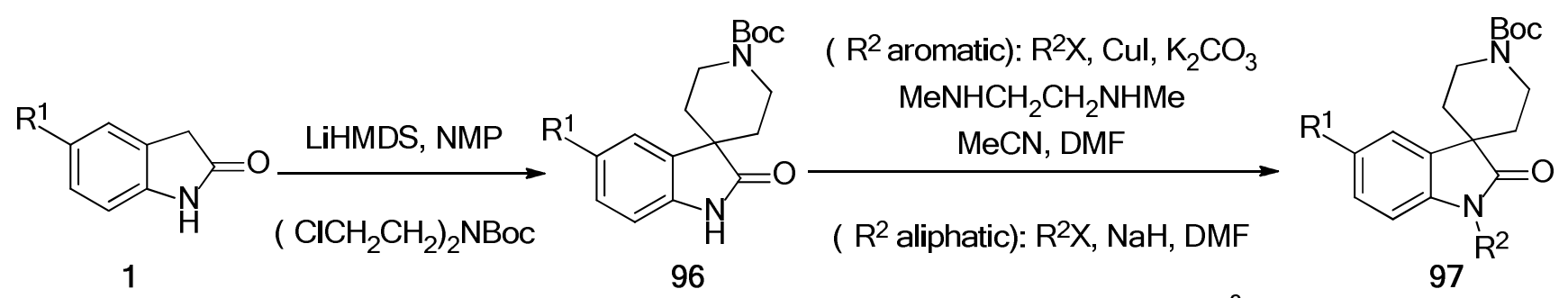<smiles>[R16]c1ccc2c(c1)C1(CCN([R1])CC1)C(=O)N2[R1]</smiles>

\section{Scheme 32}


Vachal and coworkers published a study on spirooxindoles that were optimized for prolyl hydroxylase (PHD2) inhibition. In this work, 1,3,8-triazaspiro[4.5]decane-2,4-diones 98 (spirohydantoins) were optimized as an advanced lead class derived from the original spiroindole hits 96 (Scheme 32). ${ }^{49}$ These compounds have been investigated as a structural class of pan-inhibitors of the PHD family of enzymes for anemia treatment.

\subsection{Reactions with alcohols}

Mono-3-alkylation of oxindole 1 with alcohols 99 was mediated by the in situ generated catalyst from $\mathrm{RuCl}_{3} \cdot \mathrm{xH}_{2} \mathrm{O}$ and $\mathrm{PPh}_{3}$ in the presence of sodium hydroxide (Scheme 33). ${ }^{50} \mathrm{~A}$ wide range of aromatic, heteroaromatic, and aliphatic alcohols were used successfully in this reaction. This reaction was also carried out using iridium chloro-bridged compound $\left[\mathrm{Cp}^{*} \mathrm{IrCl}_{2}\right]_{2}$ as an effective catalyst under solvent-free thermal or microwave conditions ${ }^{51}$ and also using an indenefunctionalized mesoporous iridium catalyst. ${ }^{52}$
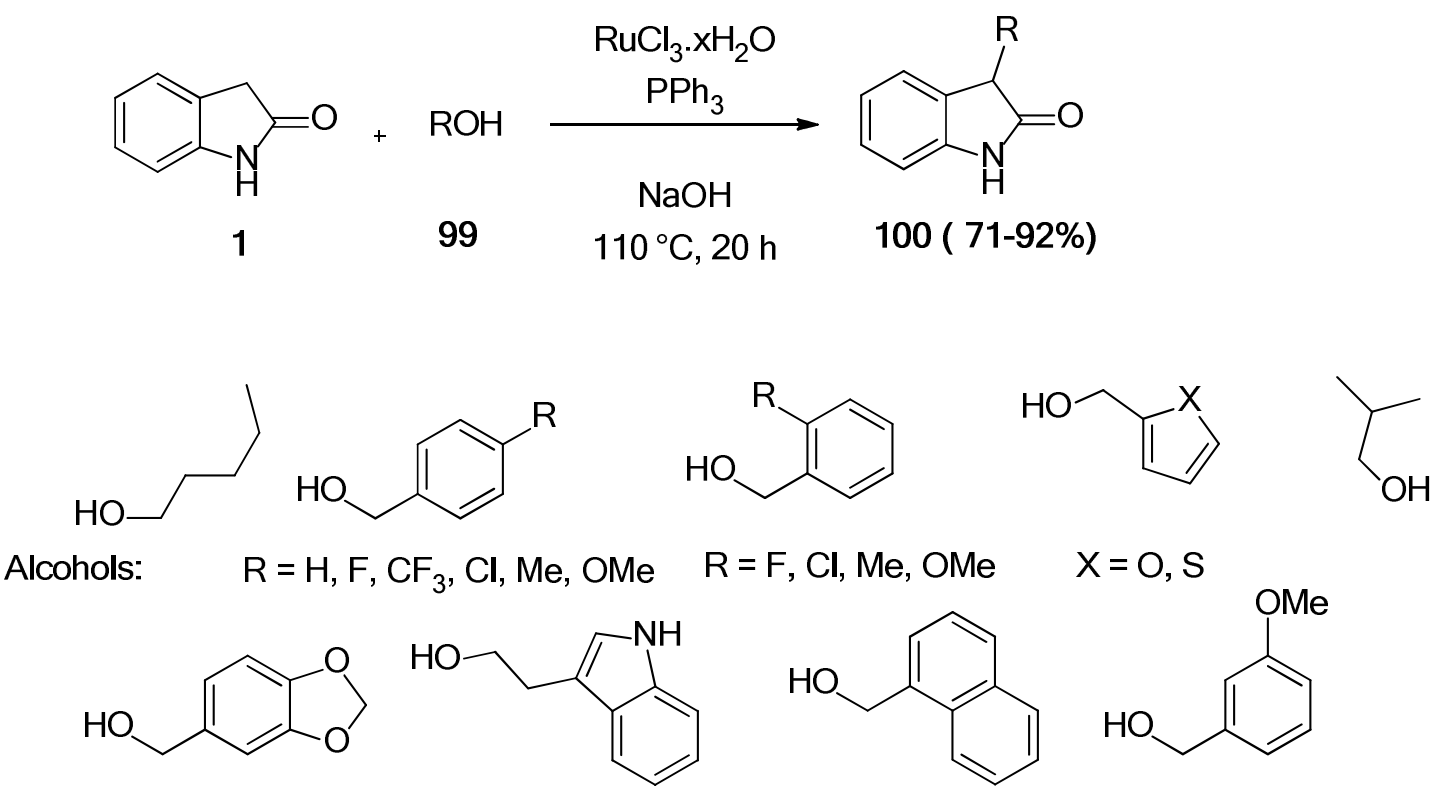

\section{Scheme 33}

The reaction of oxindoles 1 with 5-hydroxypyrazolidines 101 on the surface of potassium fluoride-modified alumina to give 3-(5-pyrazolidinyl)oxindoles $\mathbf{1 0 2}$ has been studied by Dlinnykh and coworkers (Scheme 34). ${ }^{53}$ The use of potassium fluoride-modified alumina in benzene has been proved optimal for the all substrate pairs and the reactions were completed at $60{ }^{\circ} \mathrm{C}$ after $30-60$ minutes. 


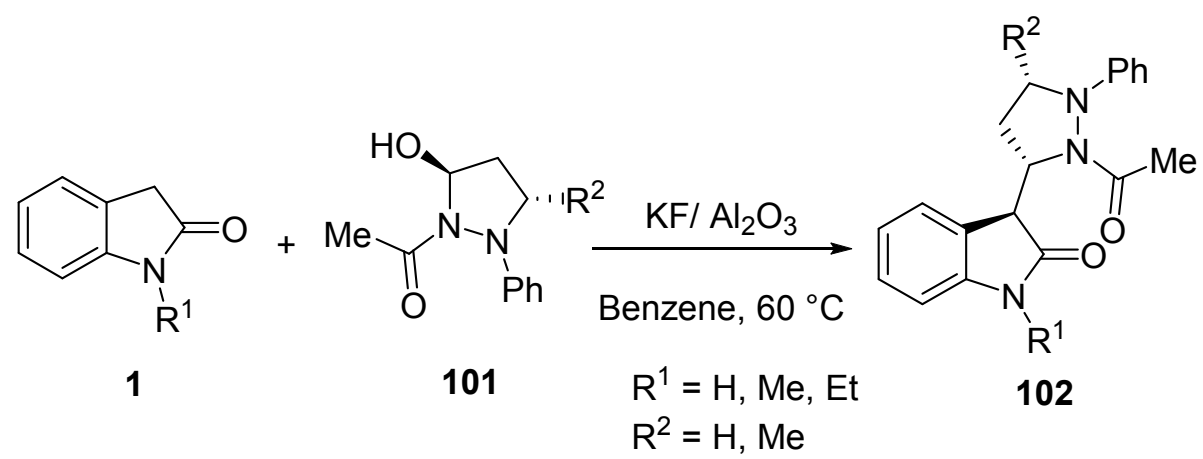

\section{Scheme 34}

\subsection{Michael additions}

Oxindoles 1 could react with unsaturated aldehydes 103 via a Michael-Michael-aldol reaction to furnish the desired spirocyclic compounds 105 (Scheme 35). ${ }^{54}$ Application of catalyst 104 as an organocatalyst in this method follows the rules of green and sustainable chemistry.

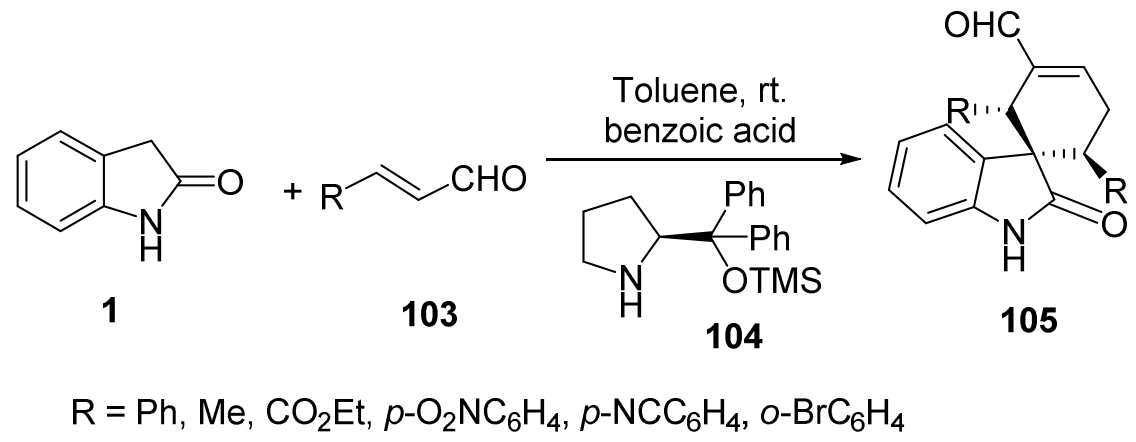

\section{Scheme 35}

Bis-(2,4-dimethyl-3-ethoxycarbonylpyrrolyl)methene (106), with high reactivity under basic conditions, acts as useful electrophilic reagent in treatment with oxindole $\mathbf{1}$ to form compound $\mathbf{1 0 7}$ which has been discovered as a new histone deacetylase (HDAC) inhibitor (Scheme 36). ${ }^{55}$

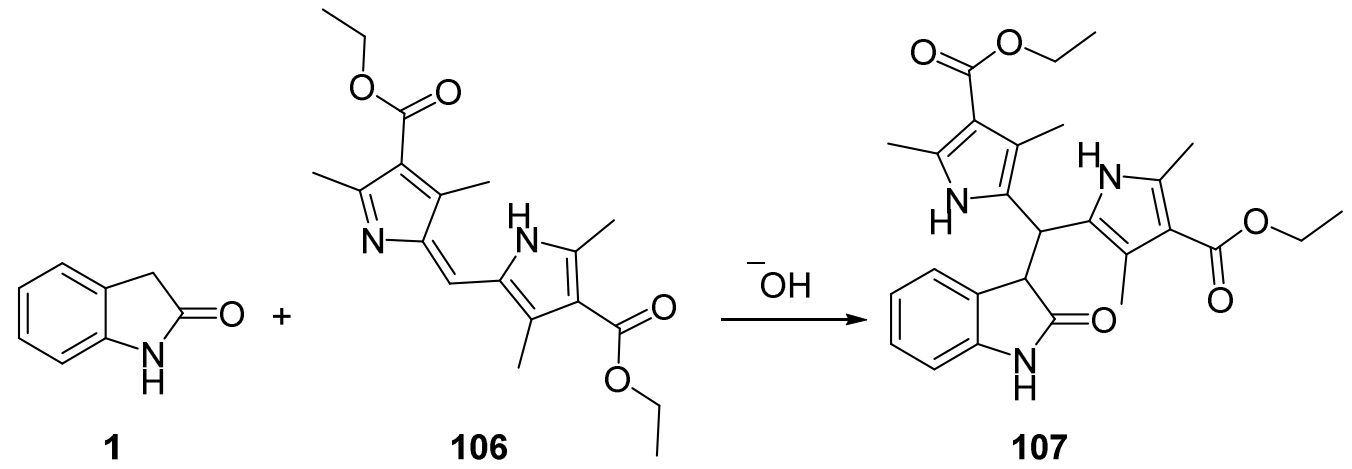

\section{Scheme 36}


4-Phenyl-1,2,4-triazolinedione (PTAD, 108) reacts with oxindole 1 to give the urazolyl compound 109 in the absence of a catalyst (Scheme 37). ${ }^{56}$ However, with simpler carbonyl systems the reaction is greatly accelerated by an acid catalyst such as trifluoroacetic acid.

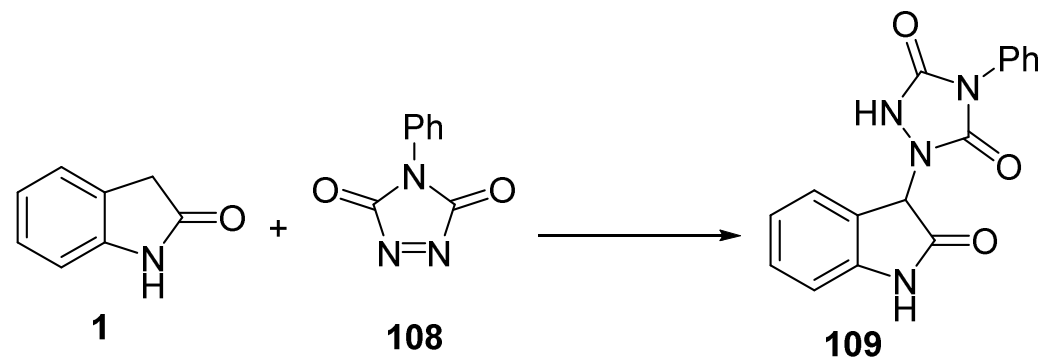

\section{Scheme 37}

\subsection{Reactions with nitriles}

Activated nitriles were used as starting materials to afford biologically activate fused heterocyclic compounds. Mahmoud and coworkers performed a condensation reaction between oxindole 1 and compound 110 upon treatment with piperidine to afford 3-arylidene oxindole 111 and pyrano[2,3b]indole 112 (Scheme 39). Compound 112 also could be obtained from the reaction of 111 with malononitrile in refluxing EtOH in the presence of piperidine, while subsequent reaction of 111a with hydrazine hydrate afforded the azine compound 113. Similarly, the reaction of 2bromobenzaldehyde with oxindole under the same conditions yielded the 3-(2bromobenzylidene)oxindole 111b that when fused with malononitrile afforded pyrido[2,3-b]indole 114. Treatment of compounds 111a,b with acetic anhydride yielded the $\mathrm{N}$-acyl derivative 115a,b which the reaction of $\mathbf{1 1 5} \mathbf{b}$ with $\beta$-cyanoethylhydrazine in ethanol yielded pyrazolo[3,4-b]indole 116 (Scheme 38). ${ }^{57}$ Compounds $\mathbf{1 1 4}, 115$ and 116 proved to possess marked activity against $E$. coli, S. aureus, and C. albicans. 


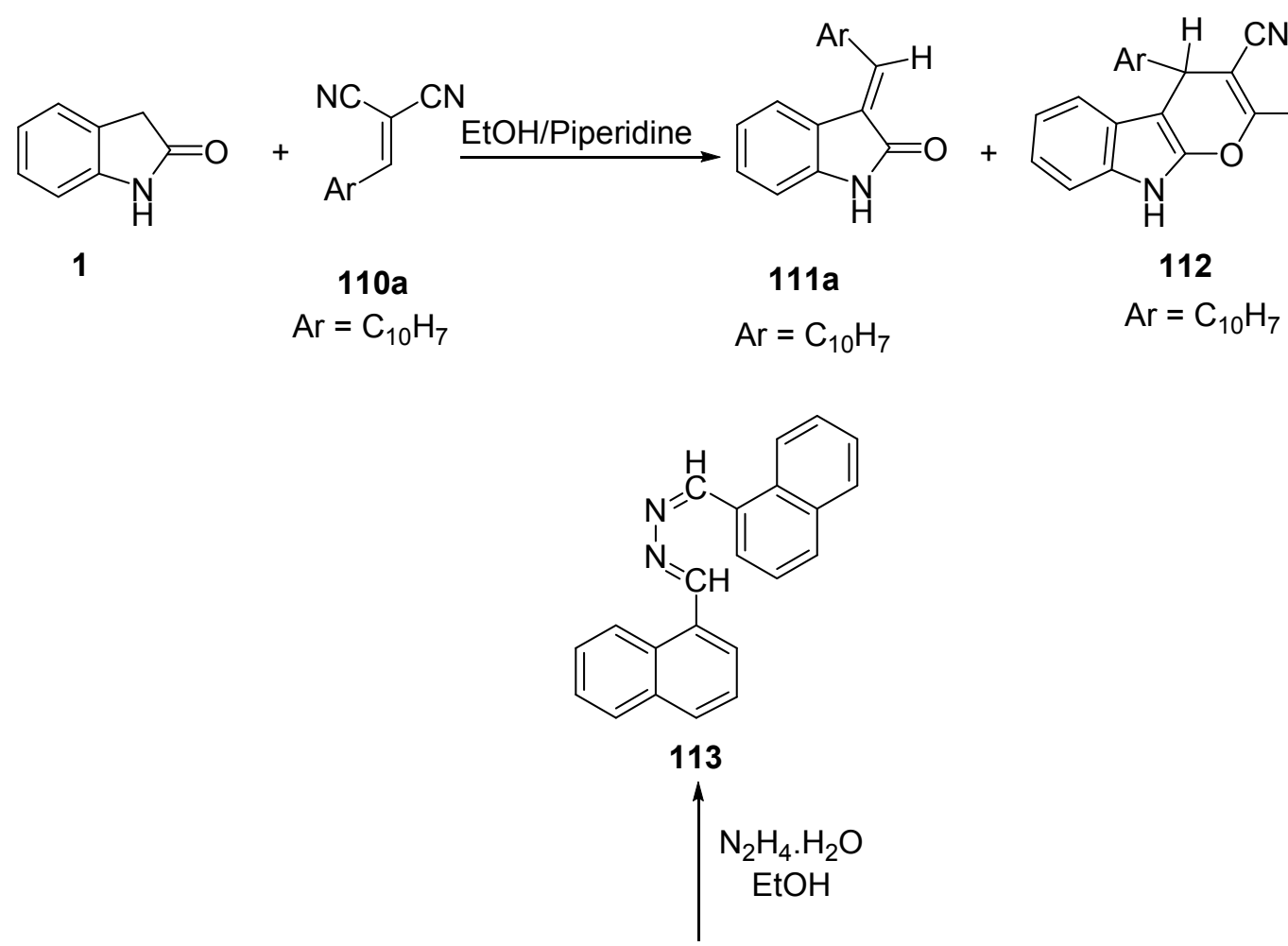<smiles>N#Cc1c(N)nc2[nH]c3ccccc3c2c1Br</smiles>

114

$\mathrm{Ar}=\mathrm{C}_{6} \mathrm{H}_{4} \mathrm{Br}$

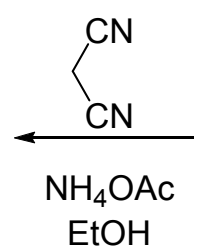
$\mathrm{EtOH}$<smiles>O=C1Nc2ccccc2/C1=C/Br</smiles><smiles>CCO[Pb]([O])(CCC#N)OCC</smiles>

111 a $\mathrm{Ar}=\mathrm{C}_{10} \mathrm{H}_{7}$ b $\mathrm{Ar}=\mathrm{C}_{6} \mathrm{H}_{4} \mathrm{Br}$<smiles>N#CC1=C(N)Oc2[nH]c3ccccc3c2C1(Br)Br</smiles>

112 $\mathrm{Ac}_{2} \mathrm{O}$

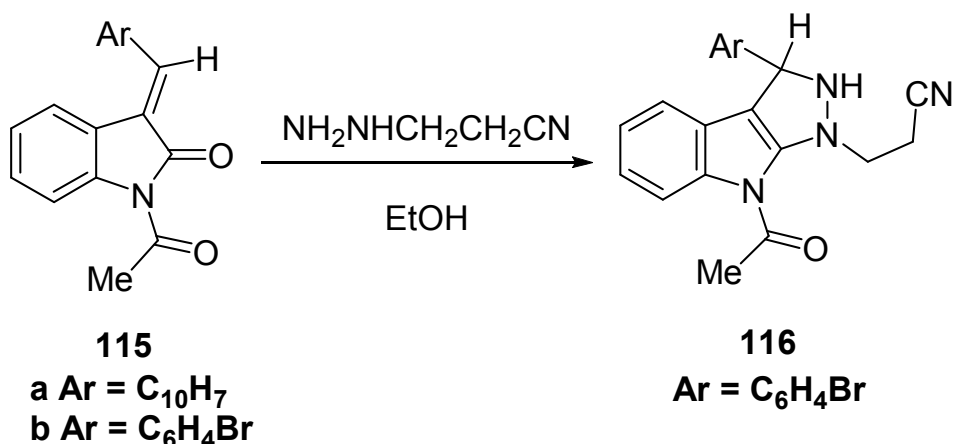

Scheme 38 


\section{Reactions on the Nitrogen Atom}

\subsection{Reactions with halogen compounds}

The coupling of aryl bromides or iodides 117 with oxindole 1 in the presence of a copper iodide$N, N^{\prime}$-dimethylethylenediamine (DMEDA) catalytic system was reported (Scheme 39). ${ }^{58}$ Aryl iodides tend to give higher yields and shorter reaction times than the corresponding bromides.

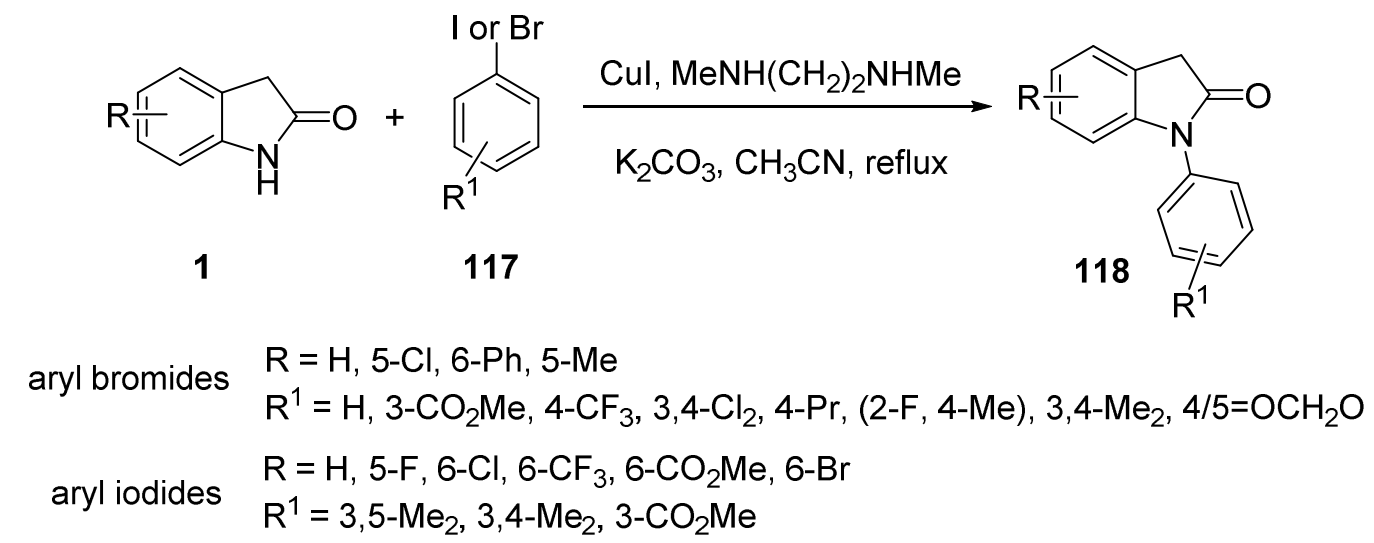

\section{Scheme 39}

Ethyl 2-oxo-2,3-dihydroindole-1-carboxylate (119) obtained in $80 \%$ yield from oxindole 1, could represent a useful building block for the synthesis of the corresponding triflate. Thus, 2trifluoromethanesulfonyloxyindole-1-carboxylic acid ethyl ester $\mathbf{1 2 0}$ has been prepared by the treatment of 119 with triflic anhydride $\left(\mathrm{CF}_{3} \mathrm{SO}_{2}\right)_{2} \mathrm{O}$ at room temperature in the presence of diisopropylethylamine (Scheme 40). ${ }^{59}$

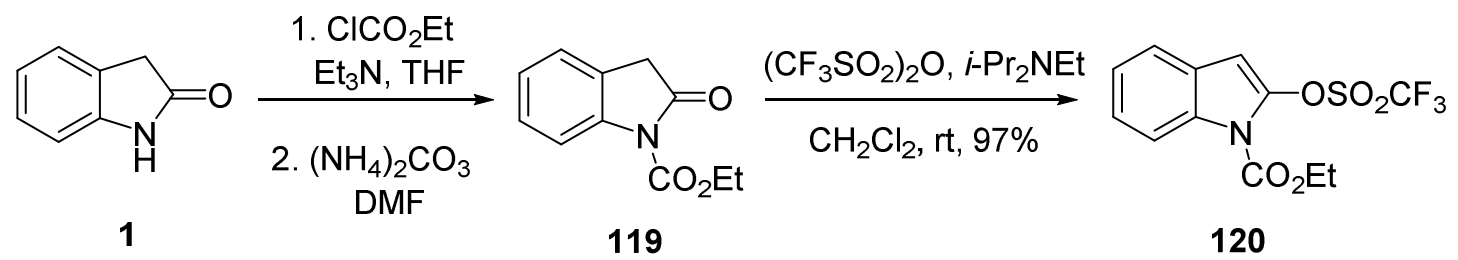

\section{Scheme 40}

Trost and Stiles have synthesized the $N$-substituted oxindole 122 by the copper-catalyzed coupling reaction between oxindole 1 and allenyl halide 121 (Scheme 41). ${ }^{60}$ Copper thiophene-2carboxylate (CuTC) was selected as a source of copper (I) because of its shelf-stability. This reaction was also carried out with chiral allenyl iodides using catalytic copper (I) salt and $N, N^{\prime}$ dimethylethylenediamine. ${ }^{61}$ 


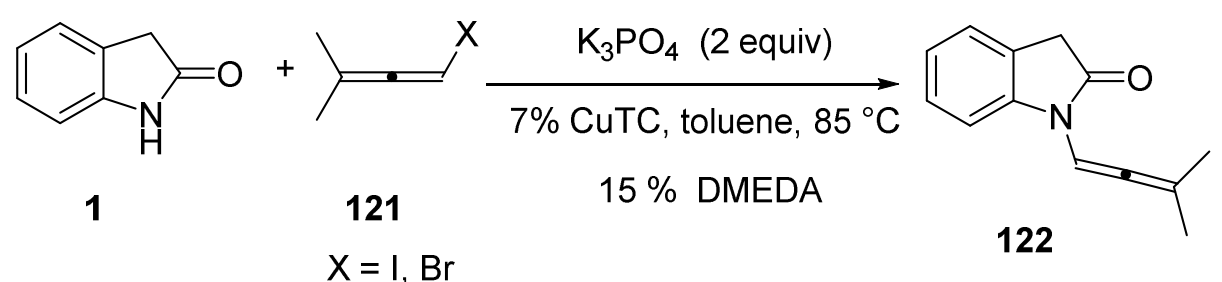

\section{Scheme 41}

The cross-amination of oxindole $\mathbf{1}$ with ortho-xylene $\mathbf{1 2 3}$ in the presence of (diacetoxy)iodobenzene and 1,1,1,3,3,3-hexafluoro-2-propanol (HFIP) has been described which resulted in the formation of desired product, $N$-aryl-2-oxindole 124, as a single regioisomer (Scheme 42). ${ }^{62}$

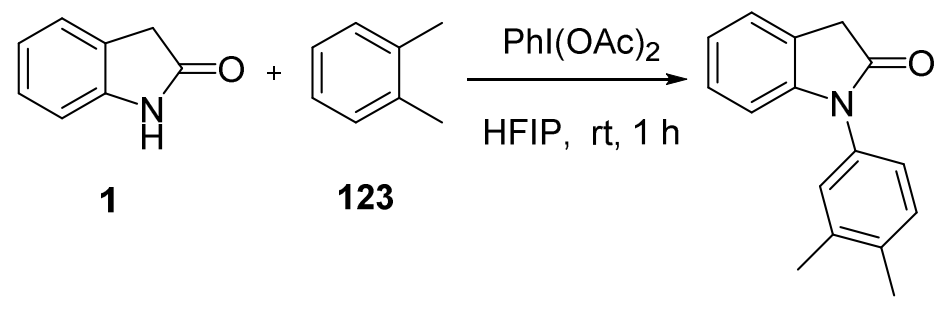

$124(51 \%)$

\section{Scheme 42}

\subsection{Reactions with alcohols}

The reaction of oxindole $\mathbf{1}$ with 1-(hydroxymethyl)benzotriazole $\mathbf{1 2 5}$ in acetic acid or in refluxing toluene in the presence of $p$-toluenesulfonic acid afforded compound $\mathbf{1 2 6}$ in good yield (Scheme 43). ${ }^{63}$<smiles>O=C1Cc2ccccc2N1</smiles>

\section{Scheme 43}

\subsection{Reactions with anhydrides}

4-Dimethylaminopyridine (DMAP) is a general catalyst well-known to catalyze acylation reactions involving a variety of functional groups. ${ }^{64,65}$ Protection of oxindoles was carried out using Bocanhydride and DMAP in acetonitrile. Application of this procedure to oxindole 1a yielded $N$-Bocoxindole 127a in $67 \%$ yield. But, treatment of 3-methyloxindole 1b with $\mathrm{Boc}_{2} \mathrm{O}$ and DMAP under 
the same condition, yielded a complex mixture of mono and diacylated derivatives from which $\mathrm{N}$ Boc-3-methyloxindole 127b was isolated in 30\% yield (Scheme 44$).{ }^{66}$

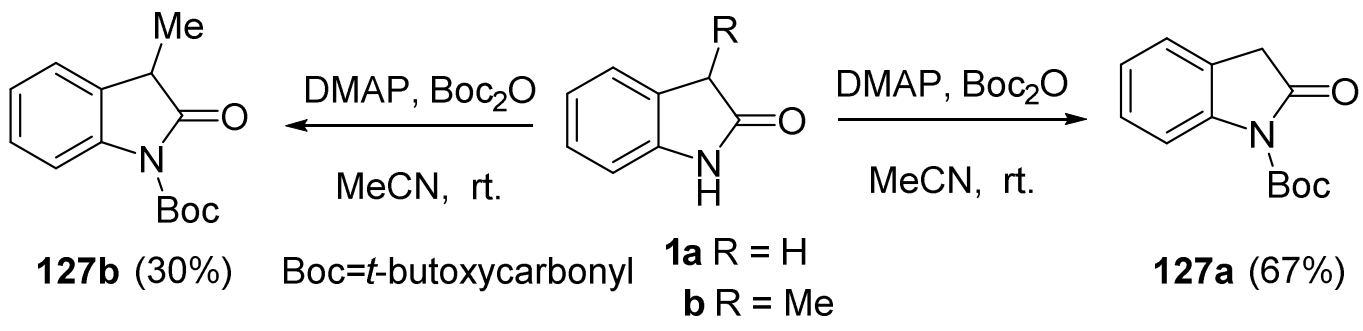

\section{Scheme 44}

Oxindoles 131 having a chiral quaternary carbon center at the C-3 position, were synthesized via an enantioselective desymmetrization of prochiral 1,3-diols 129. Using a Candida rugosa lipase (Meito OF) and a prominent acyl donor, 1-ethoxyvinyl 2-furoate 130, is the key step of this reaction (Scheme 45). ${ }^{67}$

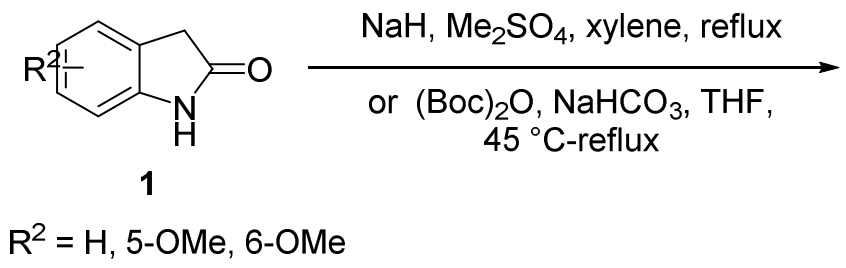<smiles>[R]N1C(=O)Cc2cc[R]cc21</smiles>

aq. $37 \% \mathrm{CH}_{2} \mathrm{O}, \mathrm{Na}_{2} \mathrm{CO}_{3}$ 128<smiles>[R]N1C(=O)C(CO)(CO)c2cc[R1]cc21</smiles>

129 a $(99 \%)$

b,c $(89 \%)$

d $(95 \%)$<smiles>C=C(OCC)OC(=O)c1ccco1</smiles>

Lipase OF wet $i-\mathrm{Pr}_{2} \mathrm{O}-\mathrm{THF}$ a $R$

b $R^{1}=$ Boc,$R^{2}=H$

c $\mathrm{R}^{1}=\mathrm{Boc}, \mathrm{R}^{2}=5-\mathrm{OM}$

d $\mathrm{R}^{1}=\mathrm{Boc}$

\section{Scheme 45}

\subsection{Reactions with alkynes}

Oxindole 1 in the presence of a cobaltocyclopentadiene complex $\mathrm{CpCo}\left(\mathrm{C}_{2} \mathrm{H}_{4}\right)_{2}$ reacts with $\alpha, \omega$ diynes 133 to give new dienamides 134 with control of regio- and stereochemistry (Scheme 46). ${ }^{68}$ Dienamides are starting materials for the preparation of polycyclic systems. 
<smiles>O=C1Cc2ccccc2N1</smiles>

1

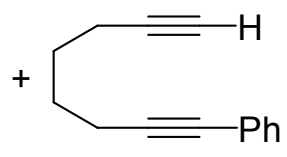

133

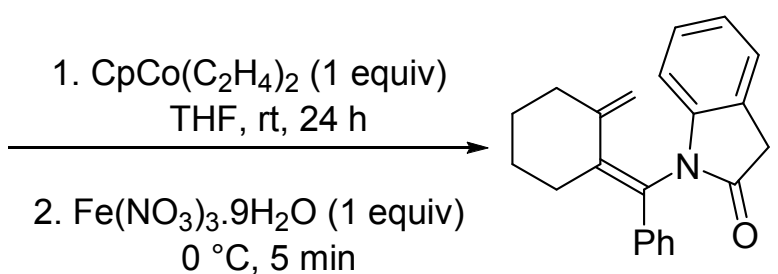

134

\section{Scheme 46}

\subsection{Competition between $\mathrm{C}-3$ and nitrogen alkylation}

In the cross-coupling reactions of unprotected oxindoles $\mathbf{1}$ with aryl halides, $\mathrm{Pd}$ - and $\mathrm{Cu}$-based catalyst systems displayed orthogonal chemoselectivity. A Pd-dialkylbiarylphosphine-based catalyst chemoselectively arylated oxindole at the C-3 position 137, while arylation occurred exclusively at the nitrogen atom 136 using a Cu-diamine-based catalyst system (Scheme 47). ${ }^{69}$<smiles>[R]c1cccc(C2C(=O)Nc3ccccc32)c1</smiles>

137

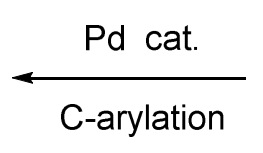<smiles>O=C1Cc2ccccc2N1</smiles>

1<smiles>[X]c1cccc([R])c1</smiles>

135

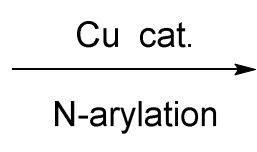

$\mathrm{X}=\mathrm{I}, \mathrm{Br}$

$\mathrm{R}=4-\mathrm{OMe}, 4-\mathrm{CF}_{3}$, 3-NO $, 4-\mathrm{Br}, 4-\mathrm{F}, 4-\mathrm{Cl}$, 4-CN, 3-OMe, 4- $\mathrm{NMe}_{2}, 3-\mathrm{CO}_{2} \mathrm{Et}, 3,5-\mathrm{Me}_{2}$

\section{Scheme 47}

\section{Reactions on the Carbonyl Site}

\subsection{Reactions at the carbonyl carbon}

Regioselective reactions of 3-substituted 4,6-dimethoxybenzofurans 138 with oxindole 1 and triflic anhydride afforded 7- and/or 2-substituted benzofuranylindoles 139 and 140. Cyclization of compound 139 to benzofuran-fused benzocarbazoles 142 has been reported using palladium (II) acetate in acetic acid at $105{ }^{\circ} \mathrm{C}($ Scheme 48$) .{ }^{70}$ 


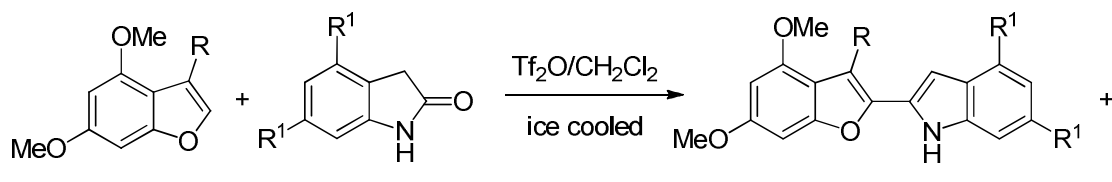

1

138

a $\mathrm{R}=\mathrm{Ph}$

b R $=4-\mathrm{BrC}_{6} \mathrm{H}_{4}$

$\mathrm{CR}=t-\mathrm{Bu}$<smiles>[R]c1ccc(-c2c(-c3cc4ccccc4[nH]3)oc3cc(OC)cc(OC)c23)cc1</smiles>

139

a $\mathrm{R}=\mathrm{H}$

$\mathrm{b} \mathrm{R}=\mathrm{Br}$

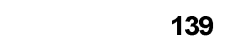

a $\mathrm{R}=\mathrm{Ph}, \mathrm{R}^{1}=\mathrm{H} \quad(58 \%)$

b $\mathrm{R}=4-\mathrm{BrC}_{6} \mathrm{H}_{4}, \mathrm{R}^{1}=\mathrm{H}(37 \%)$

$\mathrm{c} \mathrm{R}=t-\mathrm{Bu}, \mathrm{R}^{1}=\mathrm{H}$

$\mathrm{d} R=\mathrm{Ph}, \mathrm{R}^{1}=\mathrm{OMe}$

$(0 \%)$

(17\%)

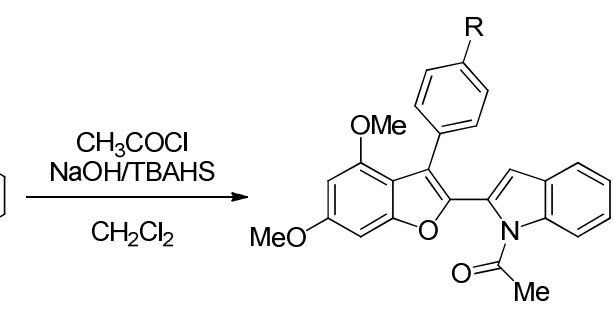

141

$\mathrm{a} \mathrm{R}=\mathrm{H} \quad(69 \%)$

$\mathrm{bR}=\mathrm{Br}(60 \%)$

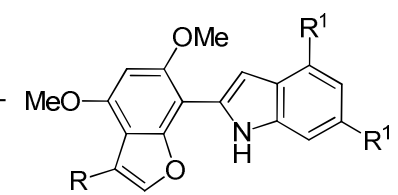

140

a $\mathrm{R}=\mathrm{Ph}, \mathrm{R}^{1}=\mathrm{H} \quad(10 \%)$

b R $=4-\mathrm{BrC}_{6} \mathrm{H}_{4}, \mathrm{R}^{1}=\mathrm{H}(28 \%)$

$\mathrm{cR}=t-\mathrm{Bu}, \mathrm{R}^{1}=\mathrm{H} \quad(87 \%)$

$\mathrm{d} R=\mathrm{Ph}, \mathrm{R}^{1}=\mathrm{OMe} \quad(0 \%)$

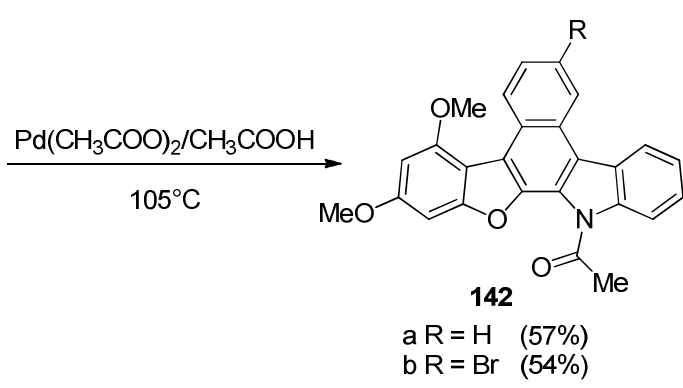

\section{Scheme 48}

The direct transformation of various secondary amides into $N$-arylimidates via mild electrophilic amide activation with trifluoromethanesulfonic anhydride $\left(\mathrm{Tf}_{2} \mathrm{O}\right)$ in the presence of 2chloropyridine (2-ClPyr) has been described. While low-temperature amide activation followed by $\mathrm{C}-\mathrm{O}$ bond formation with 2-naphthol 143 provided the desired $N$-arylimidates, in contrast, reaction with oxindole 1 proceeded via formation of a $\mathrm{C}-\mathrm{C}$ bond to give 1-(1H-indol-2-yl)naphthalen-2-ol 144 (Scheme 49). ${ }^{71}$ It is believed that the different behavior of oxindole in comparison to other amides relies on the different intermediates reacting with 2-naphthol.

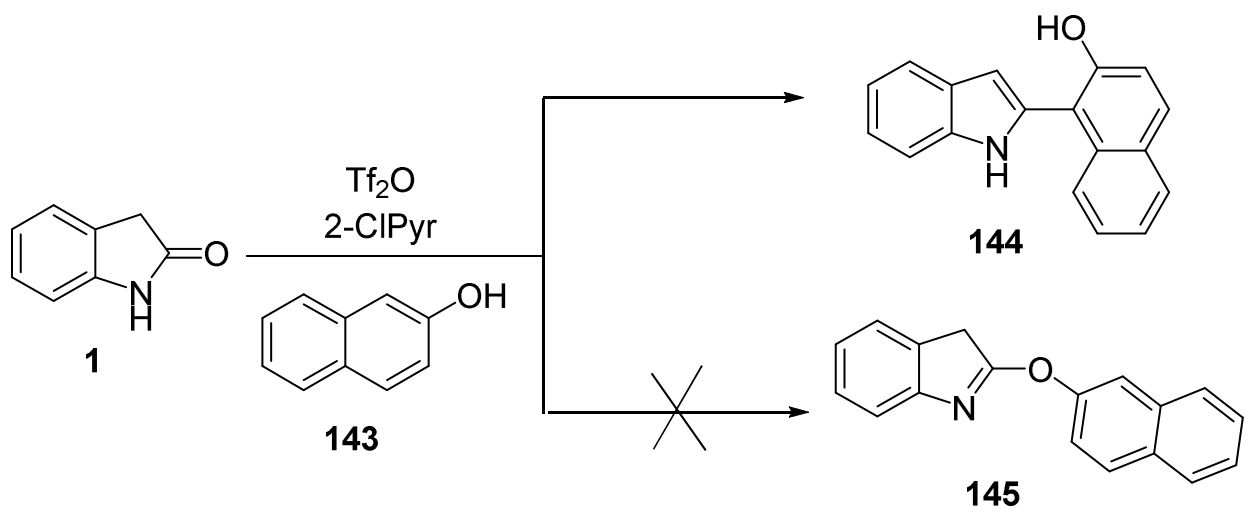

\section{Scheme 49}

Reaction of azulene derivatives 146 with oxinoles 1 in the presence of $\operatorname{Tf}_{2} \mathrm{O}$ and following hydrolysis with aq. $\mathrm{K}_{2} \mathrm{CO}_{3}$ afforded 2-(azulen-1-yl)indoles 147 in good yields (Scheme 50). ${ }^{72}$ This methodology is the first synthesis of such indole-substituted azulenes. 

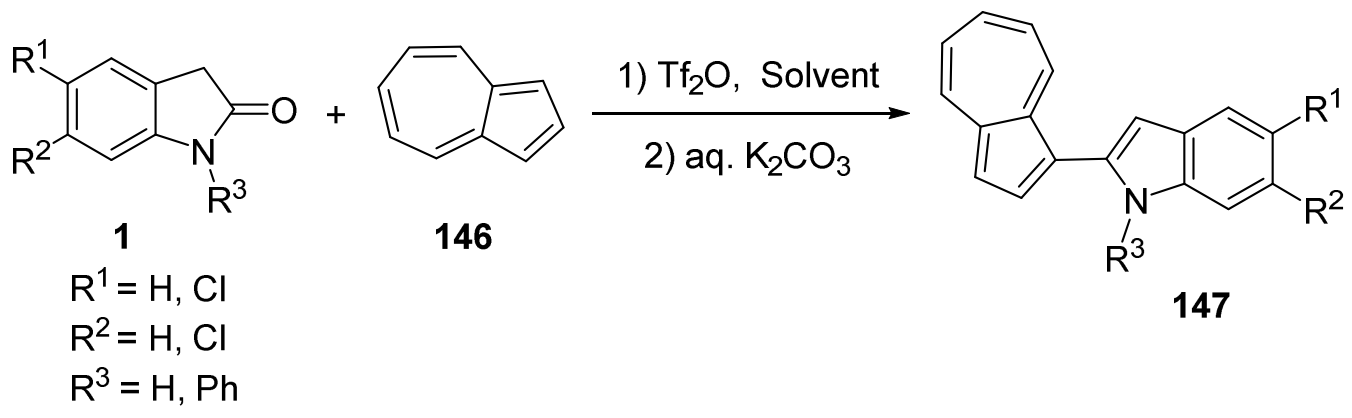

\section{Scheme 50}

Several mono- and bis-indoles with therapeutic properties, have been isolated from a marine sponge of the Ancorina species. ${ }^{73}$ Some activated 2,3'-biindolyls were prepared via modified Vilsmeier reactions. Reaction between oxindole 1 and methyl 5,6-dimethoxyindole-2-carboxylate 148 in triflic acid and following hydrolysis of the product afforded 2,3'-biindolyl 150 which was then transformed to the indolocarbazole 152 (Scheme 51). ${ }^{74}$<smiles>[R]c1cc2c(cc1[R])NC(=O)C2</smiles>

a $\mathrm{R}^{1}=\mathrm{R}^{2}=\mathrm{H}$

b $\mathrm{R}^{1}=\mathrm{NO}_{2}, \mathrm{R}^{2}=\mathrm{H}$

c $\mathrm{R}^{1}=\mathrm{R}^{2}=\mathrm{OMe}$

d $\mathrm{R}^{1}=\mathrm{H}, \mathrm{R}^{2}=\mathrm{Me}$

e $\mathrm{R}^{1}=\mathrm{H}, \mathrm{R}^{2}=\mathrm{Cl}$

1) $\mathrm{NaOH} / \mathrm{EtOH}$ $78-21^{\circ} \mathrm{C}$

2) copper/quinoline reflux
1) Triflic anhydride $/ \mathrm{CH}_{2} \mathrm{Cl}_{2}, 0-2{ }^{\circ} \mathrm{C}$

2)<smiles>COC(=O)c1cc2cc(OC)c(OC)cc2[nH]1</smiles>

148<smiles>[R]c1cc2cc(-c3c[nH]c4cc(OC)c(OC)cc34)[nH]c2cc1[R]</smiles>

$150 a \quad R^{1}=R^{2}=H(80 \%)$<smiles>COc1cc2[nH]c3ccc4c5ccccc5[nH]c4c3c2cc1OC</smiles>

$151(62 \%)$<smiles>Oc1cc2[nH]c3c(c2cc1O)-c1[nH]c2ccccc2c1CC3</smiles>

$152(67 \%)$ dimethylaminoacetaldehyde diethyl acetal

$\mathrm{AcOH} /$ reflux

\section{Scheme 51}




\subsection{Reactions on the carbonyl oxygen}

The $\mathrm{Rh}(\mathrm{II})$-catalyzed reaction of diazoacetic esters $\mathbf{1 5 3}$ with the carbonyl group of oxindole $\mathbf{1}$ is an effective method for the synthesis of the indolyloxyacetate ester $\mathbf{1 5 4}$ derived from the corresponding enolic form (Scheme 52). ${ }^{75}$

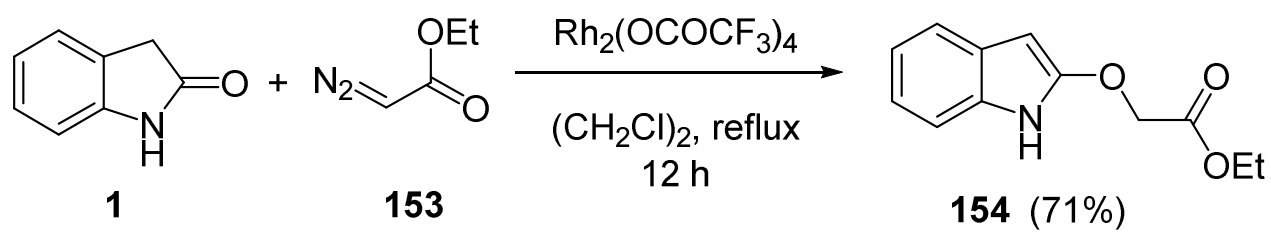

\section{Scheme 52}

\subsection{Competition between acylation at nitrogen and the carbonyl group}

Acylation of oxindole with pivaloyl chloride in the presence of $\mathrm{Et}_{3} \mathrm{~N}$ resulted in the formation of the $O$-acyl compound 157 while acylation in the presence of $\mathrm{MgBr}_{2}$. $\mathrm{Et}_{2} \mathrm{O}$ afforded $\mathrm{N}$-acyl oxindole 158 (Scheme 53). ${ }^{76}$

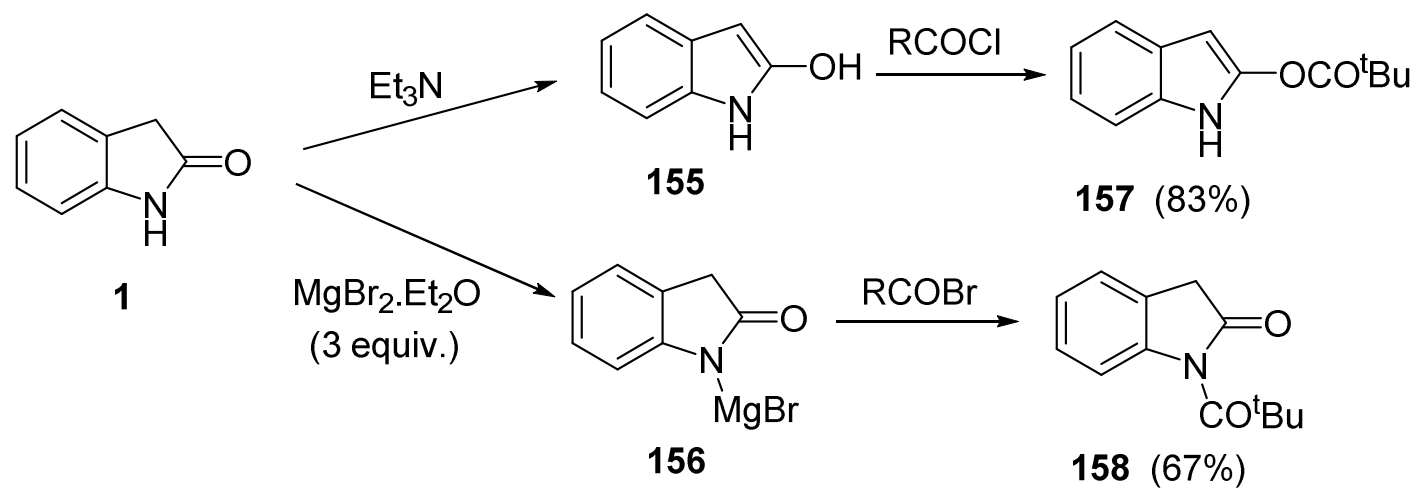

\section{Scheme 53}

\section{Reactions on the Aromatic Ring}

\subsection{Bromination of oxindole}

Bromination of oxindole 1 in aqueous solution in the presence of one, two and three equivalents of bromine yielded respectively 5-bromooxindole 159, 5,7-dibromooxindole 161 and 3,5,7tribromooxindole 163. In addition, bromination of oxindole 1 and the substituted oxindole derivatives 159 and 161 in anhydrous $\mathrm{CCl}_{4}$ afforded the corresponding 3,3-dibromooxindole derivatives 164, 160 and 162 , respectively (Scheme 54$).{ }^{77}$ 


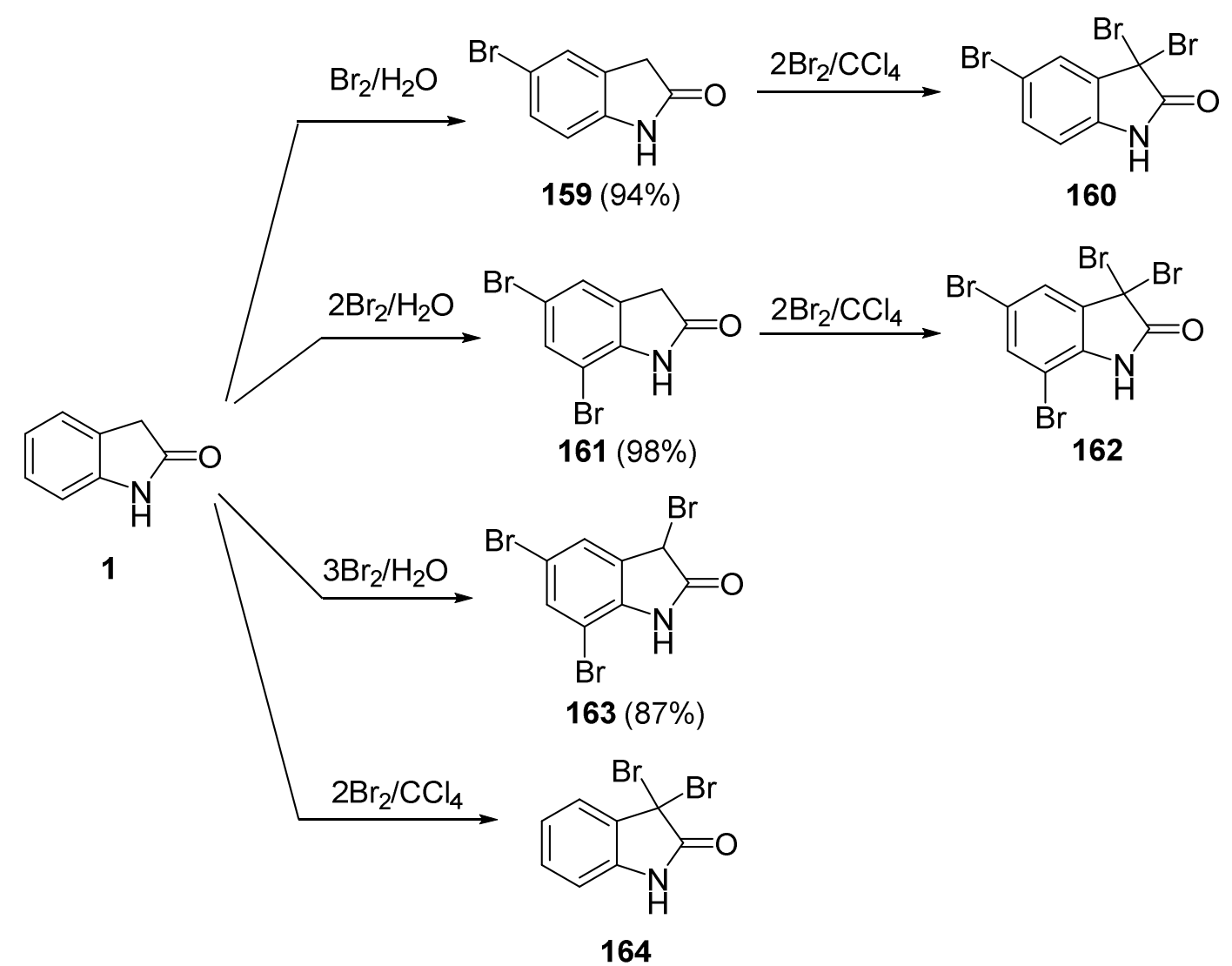

\section{Scheme 54}

\subsection{Acylation of oxindole}

Selective acylation of oxindole utilizing a variety of acyl chlorides was achieved using aluminium chloride in DMF. Acylation of oxindole with chloroacetyl chloride readily afforded the 5chloromethyl ketone derivatives $\mathbf{1 6 8}$ which were treated with thioureas and thioamides to give functionalized 5-thiazole oxindoles 169 (Scheme 55). ${ }^{78}$ 

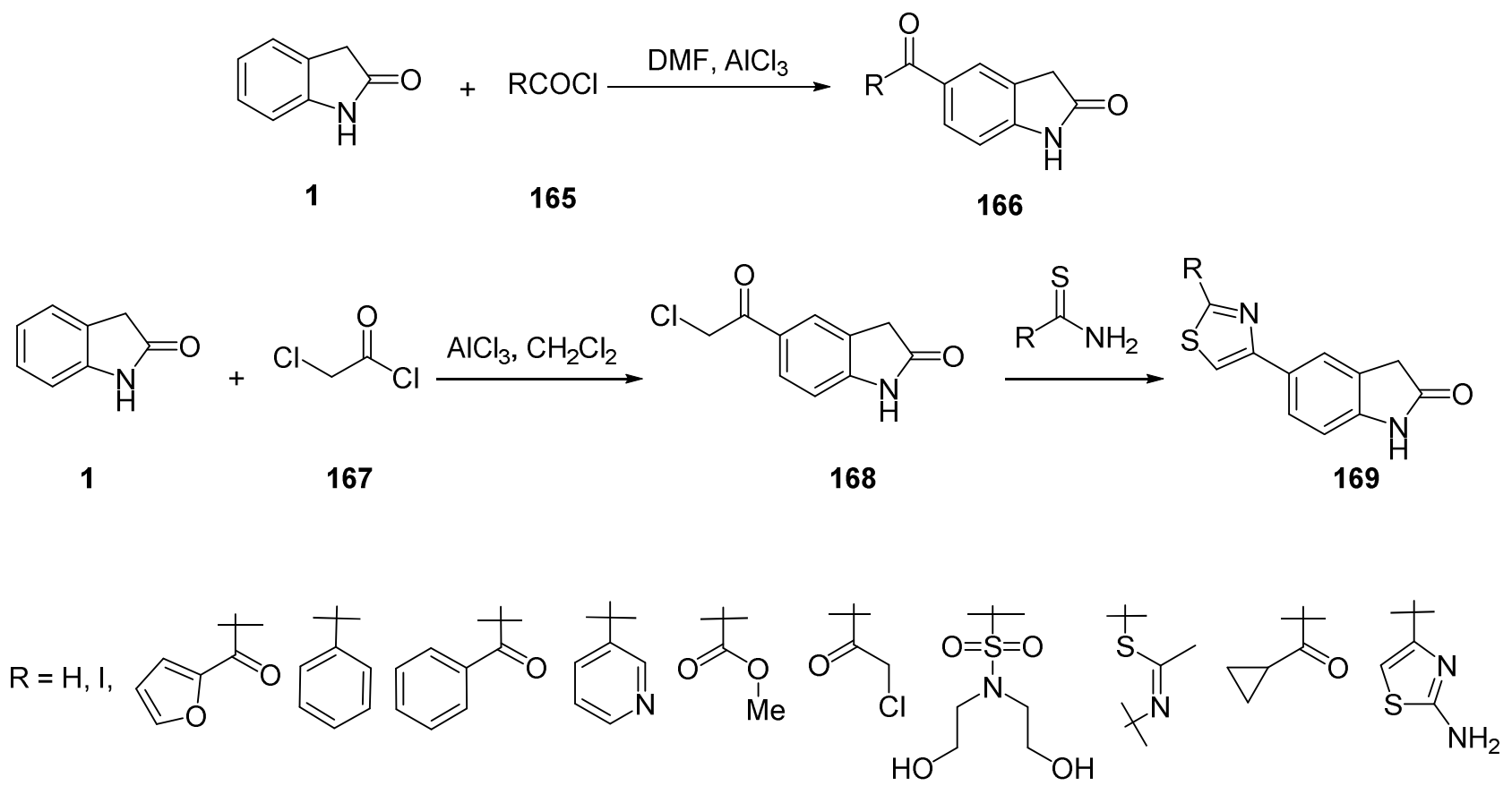

\section{Scheme 55}

\subsection{Hydroxylation of oxindole}

Treatment of oxindole 1 with phenyliodine(III) bis(trifluoroacetate) (PIFA) in trifluoroacetic acid introduced a hydroxyl group at the aromatic ring of oxindole 170 (Scheme 56). ${ }^{79}$

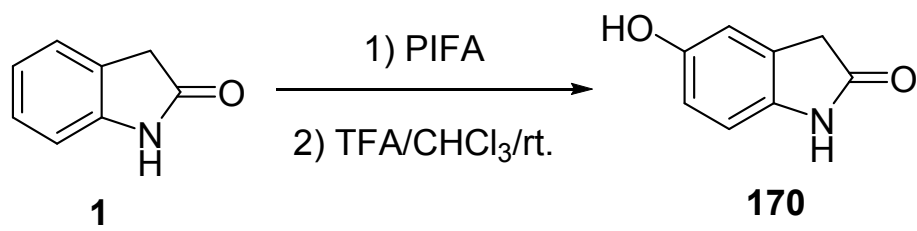

\section{Scheme 56}

\subsection{Oxindole sulfones and sulfonamides}

Lai and coworkers prepared the oxindole sulfonamide $\mathbf{1 7 1}$ by the reaction of oxindole with chlorosulfonic acid and $\mathrm{NH}_{3}$. The sulfonamide was then condensed with the indole aldehyde 173 in the presence of catalytic amount of piperidine to give the final product 174 (Scheme 57). ${ }^{80}$

A series of tetrahydroindole based indolinones $\mathbf{1 7 9}$ as tyrosine kinase inhibitors were synthesized through three steps reactions: (1) preparation of substituted oxindole cores 176 and 177 (2) preparation of functionalized pyrrole aldehydes 178 and (3) aldol condensation of the two moieties under basic condition. Oxindole sulfonamides 176 and sulfones 177 were prepared by chlorosulfonylation of oxindole to $\mathbf{1 7 5}$ followed by amidation or alkylation of the sulfonyl chloride group, respectively (Scheme 58). ${ }^{4}$ 


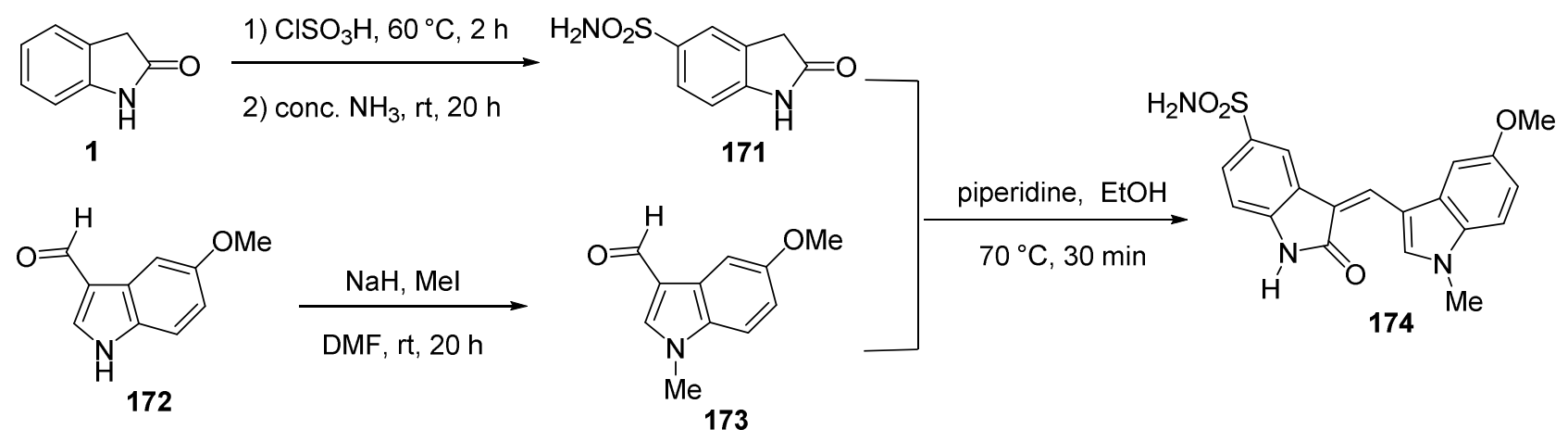

\section{Scheme 57}

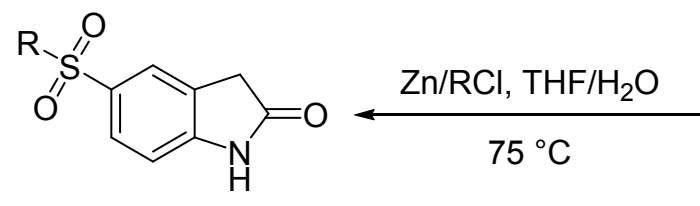

$177(60-90 \%)$<smiles>[X]c1ccc2c(c1)CC(=O)N2</smiles>

176 or 177<smiles>O=C1Cc2cc(S(=O)(=O)Cl)ccc2N1</smiles>

$175(>95 \%)$

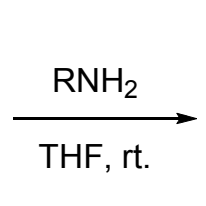<smiles>[R]NS(=O)(=O)c1ccc2c(c1)CC(=O)N2</smiles>

$176(60-100 \%)$

$$
\begin{aligned}
X= & \mathrm{SO}_{2} \mathrm{NHCH}_{3}, \mathrm{SO}_{2} \mathrm{NH}_{2}, \mathrm{SO}_{2} \mathrm{NHCH}_{2} \mathrm{CH}_{2} \mathrm{OH}, \mathrm{SO}_{2} \mathrm{NHCH}_{2}\left(4-\mathrm{F}_{-} \mathrm{C}_{6} \mathrm{H}_{4}\right), \\
& \mathrm{SO}_{2} \mathrm{NH}\left(2-\mathrm{Cl}-\mathrm{C}_{6} \mathrm{H}_{4}\right), \mathrm{SO}_{2}-\mathrm{NMe}_{2}, \mathrm{SO}_{2} \mathrm{Me}, \mathrm{SO}_{2} \mathrm{Et}, \mathrm{SO}_{2} \mathrm{CH}\left(\mathrm{CH}_{3}\right)_{2}
\end{aligned}
$$

$\mathrm{Y}=\mathrm{H}, \mathrm{CH}_{2} \mathrm{COOH},\left(\mathrm{CH}_{2}\right)_{3} \mathrm{NH}\left(\mathrm{CH}_{2} \mathrm{CH}_{2}\right)_{2} \mathrm{NCO}_{2} \mathrm{Et},\left(\mathrm{CH}_{2}\right)_{3} \mathrm{~N}\left(\mathrm{CH}_{2} \mathrm{CH}_{2}\right)_{2} \mathrm{NCOCH}{ }_{2} \mathrm{OH}$, $\left(\mathrm{CH}_{2}\right)_{3} \mathrm{~N}\left(\mathrm{CH}_{2} \mathrm{CH}_{2}\right)_{2} \mathrm{NCH}_{2} \mathrm{CO}_{2} \mathrm{Et}$,

$\left(\mathrm{CH}_{2}\right)_{3} \mathrm{~N}\left(\mathrm{CH}_{2} \mathrm{CH}_{2}\right)_{2} \mathrm{CHOH},\left(\mathrm{CH}_{2}\right)_{3} \mathrm{~N}\left(\mathrm{CH}_{2} \mathrm{CH}_{2}\right)_{2} \mathrm{NCH}_{2} \mathrm{CH}_{2} \mathrm{OH},\left(\mathrm{CH}_{2}\right)_{3} \mathrm{~N}\left(\mathrm{CH}_{2} \mathrm{CH}_{2}\right)_{2} \mathrm{NMe}$, $\left(\mathrm{CH}_{2}\right)_{3} \mathrm{~N}\left(\mathrm{CH}_{2} \mathrm{CH}_{2}\right)_{2} \mathrm{NH}$,

$\left(\mathrm{CH}_{2}\right)_{2} \mathrm{CON}\left(\mathrm{CH}_{2} \mathrm{CH}_{2}\right)_{2} \mathrm{NMe}, \mathrm{CH}_{2} \mathrm{~N}\left(\mathrm{CH}_{2} \mathrm{CH}_{2}\right)_{2} \mathrm{O}$

\section{Scheme 58}

\section{Simultaneous Participation of More than One Site in Reactions}

\subsection{C-3 and carbonyl group}

Condensation of oxindole with isatin 36a under alkaline conditions afforded the acid 180 which in treatment with diazomethane was converted into the corresponding methyl ester 181 (Scheme 59). ${ }^{81}$ 
<smiles>O=C1Cc2ccccc2N1</smiles>

1<smiles>O=C1Nc2ccccc2C1=O</smiles>

$36 a$
1) aq. $\mathrm{KOH}(20 \%)$ reflux, $4 \mathrm{~h}$

2) acetic acid 3) aq. $\mathrm{HCl}$<smiles>O=C(O)c1c2ccccc2nc2[nH]c3ccccc3c12</smiles>

$180(42 \%)$

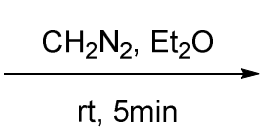<smiles>COC(=O)c1c2ccccc2nc2[nH]c3ccccc3c12</smiles>

$181(89 \%)$

\section{Scheme 59}

In another study, a solid-phase synthesis of quinoline 183 was accomplished through the reaction of oxindole and the resin-bound azomethine $\mathbf{1 8 2}^{82}$ based on Friedländer-type reaction (Scheme $60) .{ }^{83,84}$<smiles>COc1cc(N=Cc2cc(OC)c(OC)cc2N)ccc1N=Cc1ccc(Oc2ccc(Oc3ccccc3)cc2)cc1</smiles>

\section{Scheme 60}

Chuiguk found that oxindole perchlorate can react with $\beta$-diketones in alcoholic $\mathrm{HCl}$ to produce pyrano[2,3-b]indolium derivatives 186 (Scheme 61). ${ }^{85}$ Heating of 186 with $p$-dimethylamino benzaldehyde in acetic anhydride results in the formation of polymethine dyes.<smiles>O=CC1Cc2ccccc2N1</smiles>

1<smiles>[R]C(C(C)=O)=C(C)O</smiles>

185<smiles>O=CCO</smiles>

$$
18
$$

\section{Scheme 61}

Repeating the literature examples, Magnus and coworkers found that treatment of oxindole with oxalyl chloride gave a precipitate of 188 (46\%) and the filtrate contained the compound $187(42 \%)$ (Scheme 62). ${ }^{86}$ 


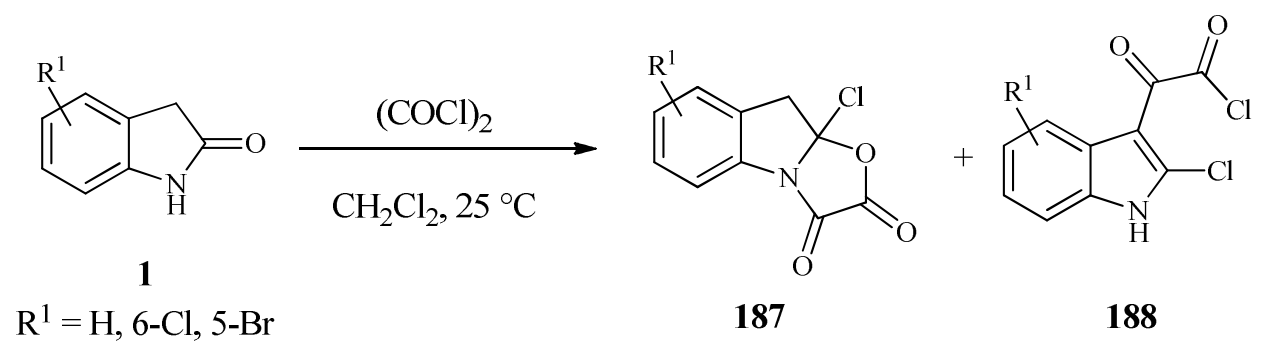

\section{Scheme 62}

In another study, Sahugan and coworkers combined indole-derived building blocks with indolylacetamides to allow the direct region-controlled synthesis of $N$-indole-monosubstituted indolopyrrolocarbazoles (IPCs).

Intermolecular Perkin-type condensation of 189 with indole-3-acetamides 190 in the presence of $\mathrm{KOtBu}$ provided unsymmetrical bisindolylmaleimides 191. Reaction of 191 with an allylic cyclopentenol under classical Mitsunobu conditions afforded the corresponding bisindolylmaleimides 193. Finally, subsequent cyclization of 193 to IPCs 194 was performed by simple irradiation with a strong light source. A second strategy was elaborated for the synthesis of the opposite regioisomers 197. Condensation of compound 195 with methyl 2-chloroindole-3glyoxylates 189 provided the corresponding functionalized bisindolyl-maleimides 196 which cyclization to the complementary IPCs 197 was achieved as described before (Scheme 63). ${ }^{87}$

The reaction of oxindole with phosphoryl chloride to give the corresponding triazatruxene 198 has been described. The $N$-alkylation with an excess of diiodobutane in basic condition followed by substitution of the iodide with piperidine resulted in the formation of Azatrux 199. The new compound Azatrux is a water-soluble triazatruxene derivative that selectively binds to Gquadruplex DNA (Scheme 64). ${ }^{88}$ 


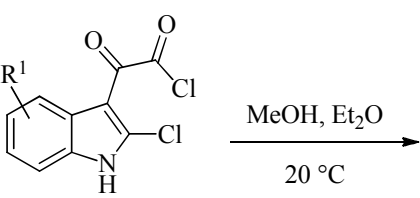

188

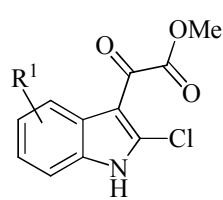

189

$$
\mathrm{R}^{1}=\mathrm{H} \quad(85 \%)
$$$$
\mathrm{R}^{1}=6-\mathrm{Cl}(56 \%)
$$$$
\mathrm{R}^{1}=5-\mathrm{Br}(38 \%)
$$

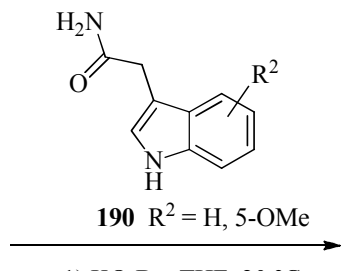

1) $\mathrm{KOtBu}, \mathrm{THF}, 20^{\circ} \mathrm{C}$

2) $\mathrm{HCl}$ concd., THF, reflux<smiles>[R][R]c1ccc2[nH]cc(C3=C(c4c(Cl)[nH]c5ccccc45)C(=O)NC3=O)c2c1</smiles>

191

$\mathrm{R}^{1}=\mathrm{H}, \mathrm{R}^{2}=\mathrm{H} \quad(49 \%)$

$\mathrm{R}^{1}=5-\mathrm{Br}, \mathrm{R}^{2}=\mathrm{H} \quad(85 \%)$

$\mathrm{R}^{1}=6-\mathrm{Cl}, \mathrm{R}^{2}=\mathrm{H} \quad(65 \%)$

$\mathrm{R}^{1}=\mathrm{H}, \mathrm{R}^{2}=\mathrm{OMe} \quad(14 \%)$

$\mathrm{R}^{1}=5-\mathrm{Br}, \mathrm{R}^{2}=\mathrm{OMe}(48 \%)$
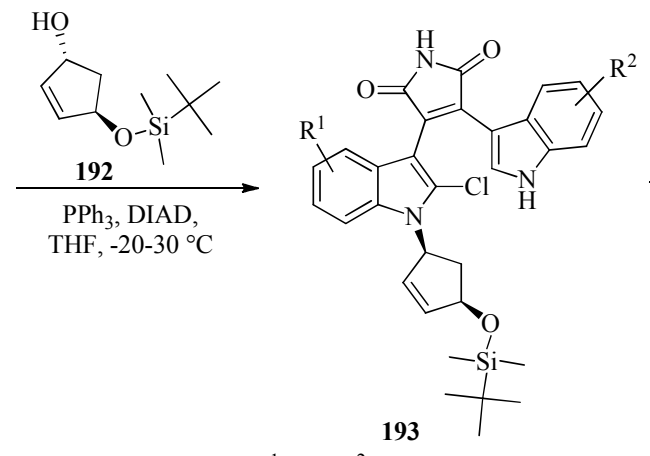

hu, $\mathrm{AcOH}$

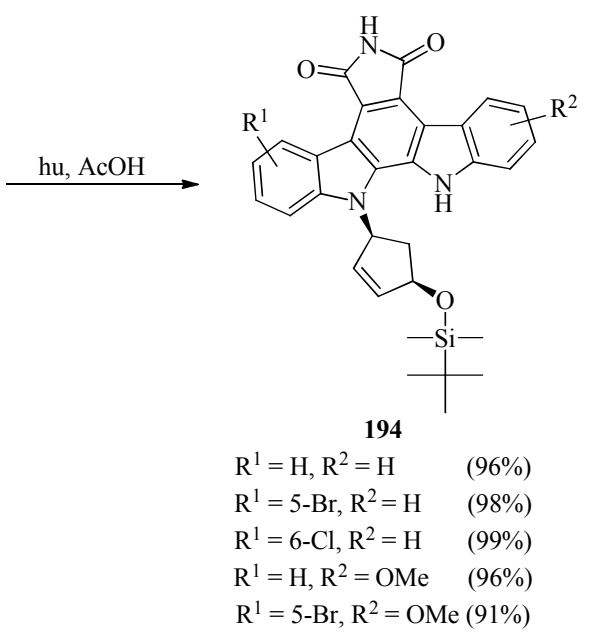

$\mathrm{R}^{1}=\mathrm{H}, \mathrm{R}^{2}=\mathrm{H} \quad(31 \%)$

$\mathrm{R}^{1}=5-\mathrm{Br}, \mathrm{R}^{2}=\mathrm{H} \quad(38 \%)$

$\mathrm{R}^{1}=6-\mathrm{Cl}, \mathrm{R}^{2}=\mathrm{H} \quad(45 \%)$

$\mathrm{R}^{1}=\mathrm{H}, \mathrm{R}^{2}=\mathrm{OMe} \quad(45 \%)$

$\mathrm{R}^{1}=5-\mathrm{Br}, \mathrm{R}^{2}=$ OMe (35\%)<smiles>COC(=O)C(=O)c1c(Cl)[nH]c2ccccc12</smiles>

189<smiles>C=CCN(C)[C@@H]1C=C[C@@H](O[Si](C)(C)C(C)(C)C)C1</smiles>

195 $\underset{\text { 2) } \mathrm{HCl} \text { conc., THF, reflux }}{\stackrel{\mathrm{KOtBu}, \mathrm{THF}, 20{ }^{\circ} \mathrm{C}}{\longrightarrow}}$

2) $\mathrm{HCl}$ conc., THF, reflux

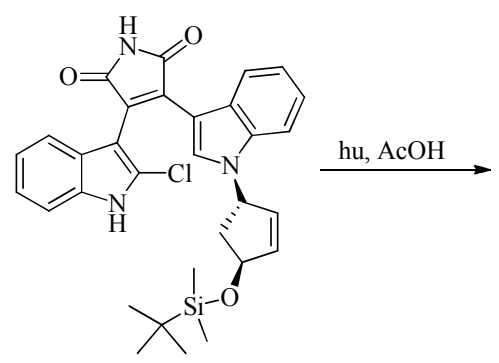

196

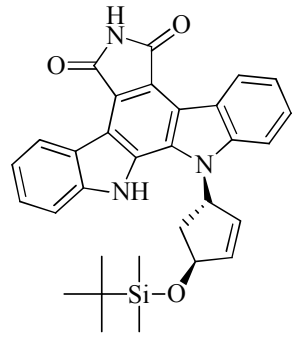

197

\section{Scheme 63}




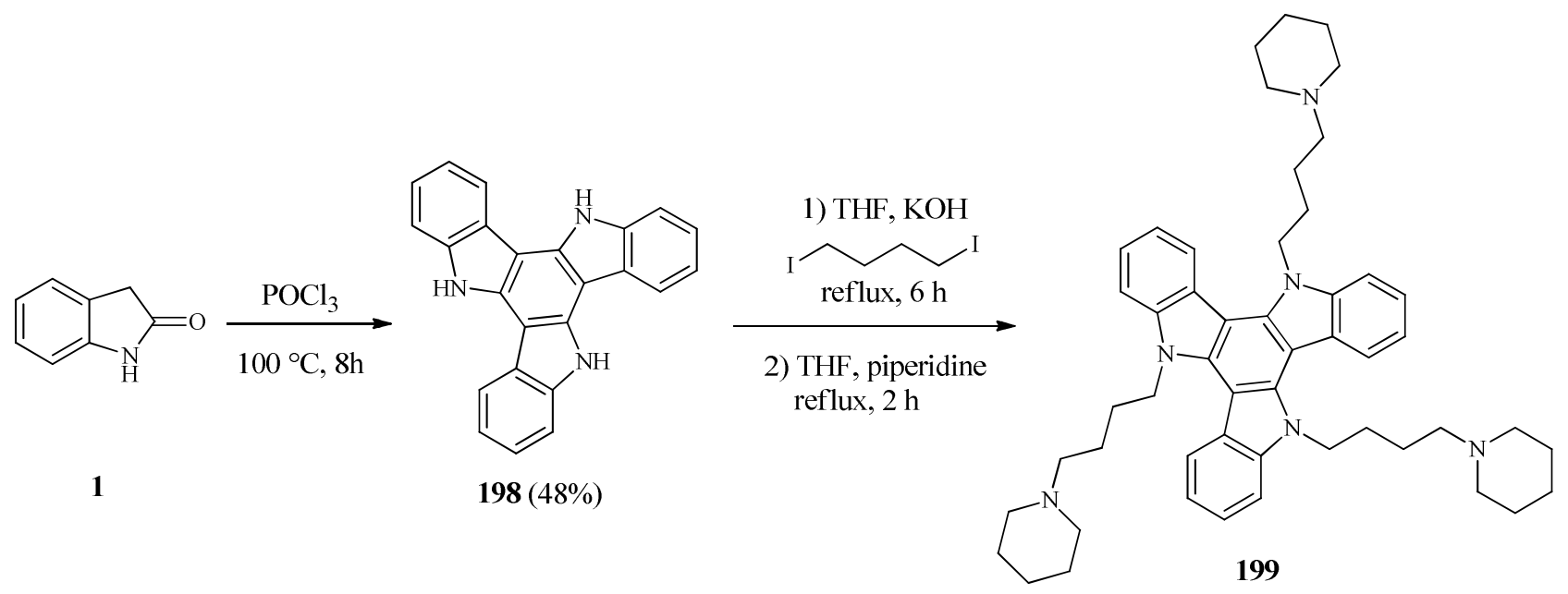

\section{Scheme 64}

An asymmetric synthesis of hexahydropyrroloindoles 203 in high enantiopurity was achieved through the dialkylation of enantiopure ditriflate $\mathbf{2 0 0}$ with 2 equiv of oxindole enolates as the central step. As dialkylation product 201 encodes 2 equiv of oxindole aldehyde 202, an attractive route to pyrrolidinoindolines $\mathbf{2 0 3}$ appeared possible (Scheme 65). ${ }^{89}$<smiles>[R]c1ccc2c(c1)[C@@H]([R])C(=O)N2[R]</smiles>

1

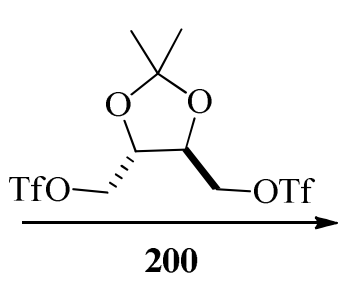

$$
\begin{aligned}
& \mathrm{R}^{1}=\mathrm{Bn}, \mathrm{Me} \\
& \mathrm{R}^{2}=\mathrm{Bn}, \mathrm{Ph}, 2 \text {-propenyl, Me, } \mathrm{CH}\left(\mathrm{CH}_{3}\right)_{2}, \mathrm{CH}_{2} \mathrm{CH}=\mathrm{C}\left(\mathrm{CH}_{3}\right)_{2} \\
& \mathrm{R}^{3}=\mathrm{H}, \mathrm{OMe}
\end{aligned}
$$<smiles>[R]c1ccc2c(c1)[C@]([R])(CC)C(=O)N2[R]</smiles><smiles>[R]c1ccc2c(c1)[C@]([R2])(CC1OC(C)(C)O[C@H]1C)C(=O)N2[R]</smiles><smiles>CC[N+](=O)[O-]</smiles><smiles>[R3]c1ccc2c(c1)[C@]([R4])(CC=O)C(=O)N2[R]</smiles>

202

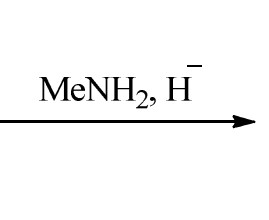

$\underbrace{\mathrm{N}_{\mathrm{N}}^{2}}_{\mathrm{R}_{\mathrm{R}^{1}}^{\mathrm{N}}}$

203

\section{Scheme 65}

\subsection{C-3 and nitrogen atom}

Reaction of oxindole with the excess of BuLi in the presence of TMEDA afforded the dianion of oxindole which can be quenched with allyl bromide to afford the monoallylated oxindole 204. 
Subjecting the Na salt of oxindole 204 to imidazole carboxylate 205 resulted in the mono- $N$ carbamoylated product 206 with high regioselectivity (Scheme 66). ${ }^{90}$

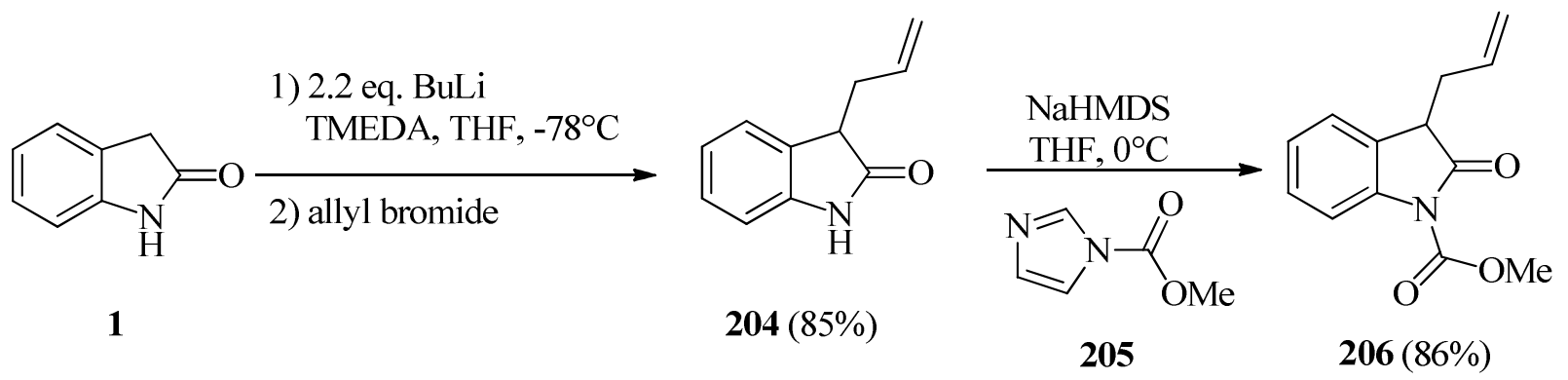

\section{Scheme 66}

Starting from oxindole and acetic anhydride, 1-acetyl-1,3-dihydro- $2 H$-indol-2-one 207 was prepared. Exhaustive methylation of $\mathbf{2 0 7}$, followed by removal of the protecting group, afforded 1,3-dihydro-3,3-dimethyl-2H-indol-2-one 209. Subsequent Friedel-Crafts acylation of compound 209 with succinic anhydride provided the 4-oxobutanoic acid 210 which its cyclization with hydrazine hydrate resulted in the formation of final product 211 (Scheme 67). ${ }^{91}$ It was shown that compound $\mathbf{2 1 1}$ is a potent positive inotrope in dogs.

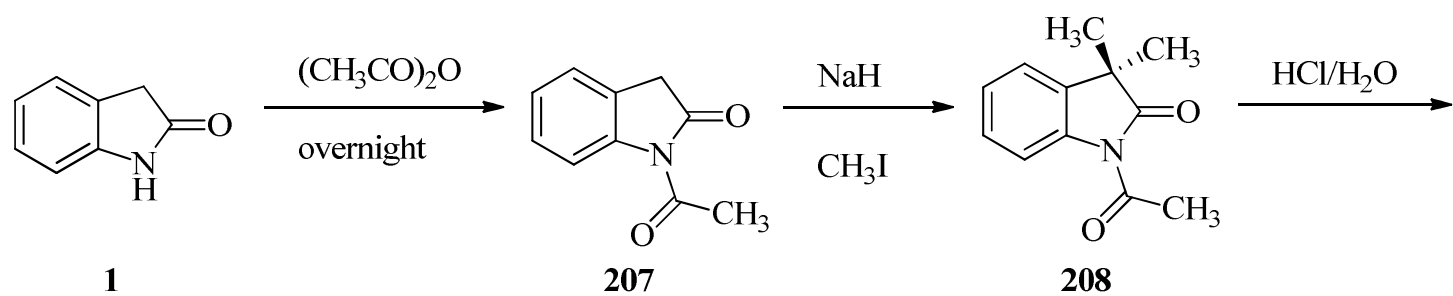

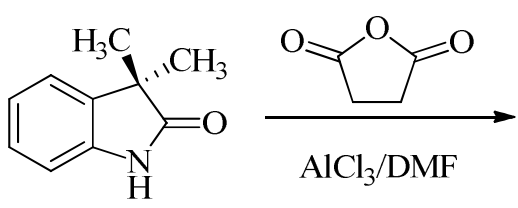

$209(59 \%)$<smiles>CC1(C)C(=O)Nc2ccc(C(=O)CCC(=O)O)cc21</smiles>

$210(74 \%)$

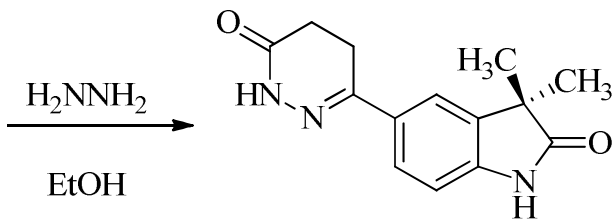

$211(88 \%)$

\section{Scheme 67}

In another study, oxindole was reacted with an excess of sodium hydride and 1,2-dibromoethane, followed by magnesium-induced debromoethylation to afford compound 213. Friedel-Crafts acylation of compound 213 with propionyl chloride yielded 214. Formation of the Mannich base, quaternarization with iodomethane, followed by reaction with potassium cyanide, produced $\gamma$-keto nitrile 215. Sequential acid-catalyzed hydrolysis and hydrazine cyclization completed the synthesis of the final product 216 (Scheme 68). ${ }^{92}$ Compound 216 is one of the most potent noncatecholamine, nonglycoside positive inotropes which has been examined. 

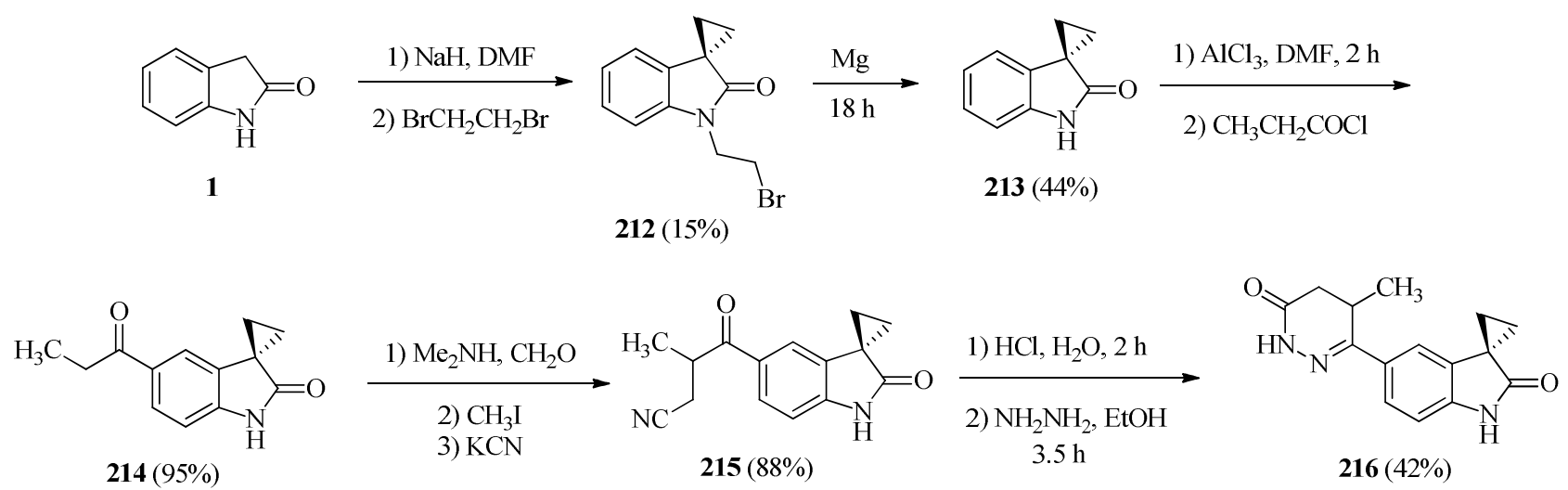

\section{Scheme 68}

The 5-, 6-, and 7-methyl derivatives of ethyl 2,3-dihydro-2-oxo- $1 H$-indole-3-propanoate 217 were prepared by the condensation of methyl-substituted oxindoles $\mathbf{1}$ with diethyl malonate $\mathbf{5 8}$. Compounds 217 undergo catalytic hydrogenation over palladium-on-carbon catalyst to the desired products 218. Thiation with $\mathrm{P}_{2} \mathrm{~S}_{5} / \mathrm{Na}_{2} \mathrm{CO}_{3}$, followed by oxidation with $\mathrm{FeCl}_{3}$ then afforded 2,2'dithiobis- $H$-indole-3-propanoates 219. Final hydrolysis of 219 with $\mathrm{LiOH}$ in aqueous EtOH resulted in 2,2'-dithiobis- $1 H$-indole-3-propanoic acids $\mathbf{2 2 0}$. In another reaction, the condensation of oxindole with ethyl acrylate followed by hydrolysis and methylation, resulted in a mixture of diand trimethyl oxindolepropanoates (222 and 221). These compounds were separated by chromatography and were thiated with $\mathrm{P}_{2} \mathrm{~S}_{5}(\mathbf{2 2 4}$ and 223) and hydrolyzed to give the diacid 225 (Scheme 69). ${ }^{93}$ 


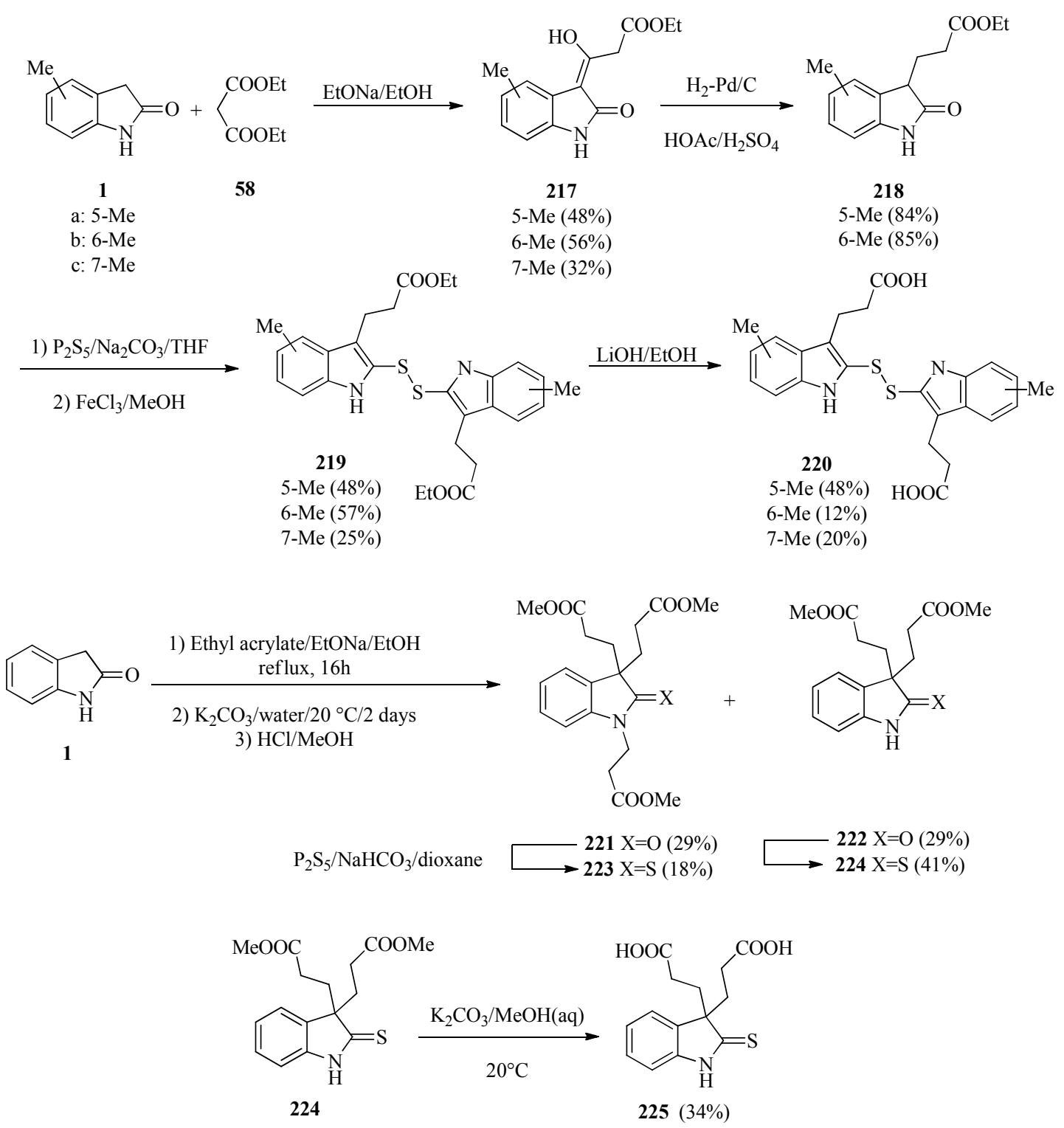

\section{Scheme 69}

Semaxinib 43 has been synthesized by the reaction between oxindole and 3,5-dimethylpyrrole2-carboxaldehyde 42, ${ }^{94}$ as described before. ${ }^{33}$ An analogous set of compounds 226, 227 and 228 was prepared from Semaxanib as outlined in Scheme 70. Diisopropyl azodicarboxylate (DIAD), phenylacetic acid derivatives, and triphenylphosphine were reacted with Semaxanib to give compounds 226a-c while compounds 227a-b were prepared by benzylation of Semaxanib. Finally, Semaxanib, dicyclohexylcarbodiimide (DCC) and DMAP were added to 3-methyl-3-(3,6-dimethyl2,5-dioxobenzen-2-yl)butanoic acid (quinone- $\mathrm{CMe}_{2} \mathrm{CH}_{2} \mathrm{CO}_{2} \mathrm{H}$ ) to generate compound 228. ${ }^{95}$ These compounds were screened for their anti-angiogenic activities. 


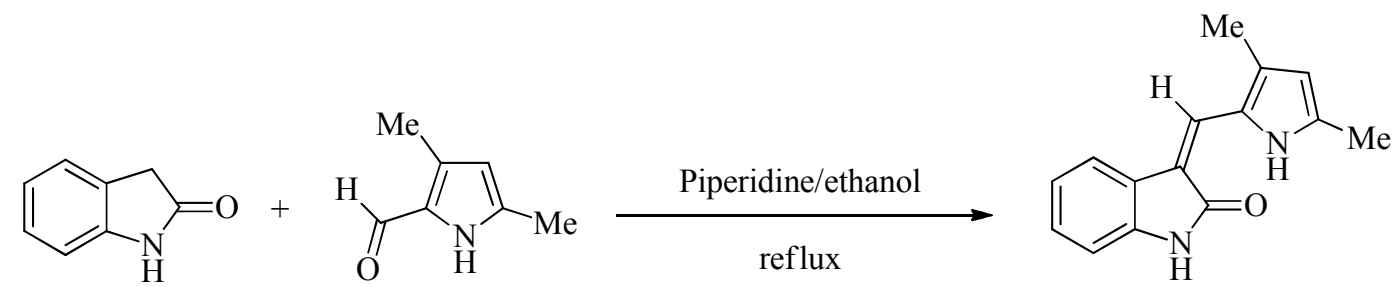

1

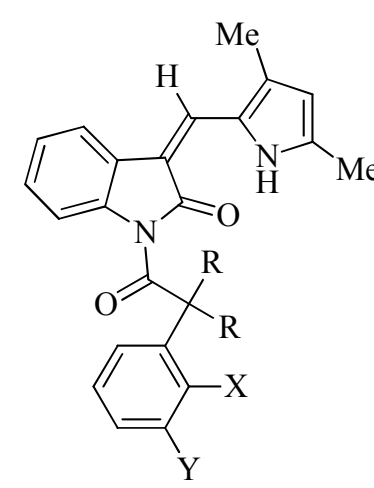

226a $\mathrm{R}=\mathrm{X}=\mathrm{H}, \mathrm{Y}=\mathrm{NO}_{2} \quad(6 \%)$

226b $\mathrm{R}=\mathrm{Y}=\mathrm{H}, \mathrm{X}=\mathrm{NO}_{2} \quad(27 \%)$

226c $\mathrm{R}=\mathrm{Me}, \mathrm{Y}=\mathrm{H}, \mathrm{X}=\mathrm{NO}_{2}(5 \%)$
42

43
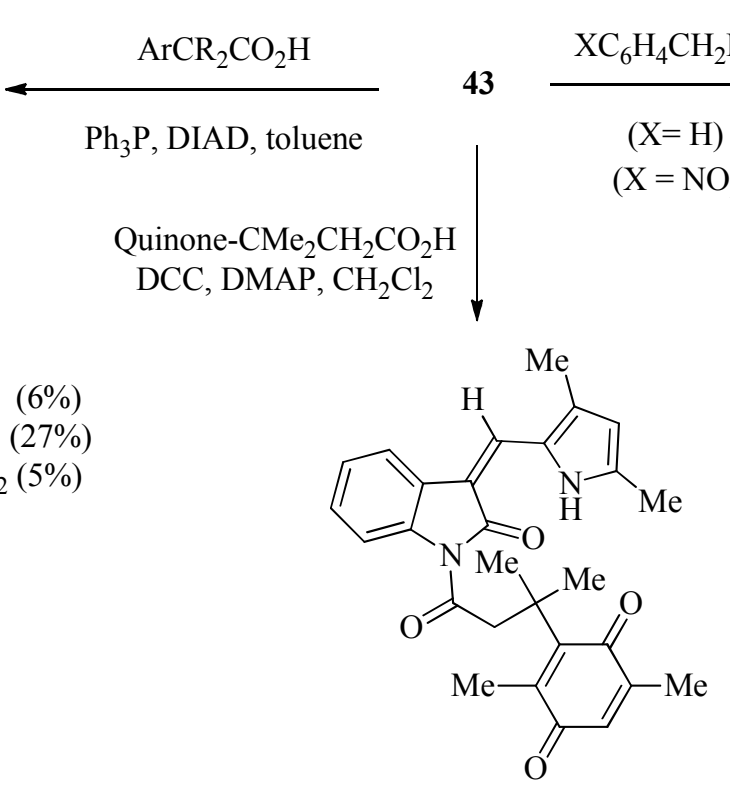

$228(52 \%)$

\section{Scheme 70}

The preparation of the oxindole acetic acids was accomplished via two general processes. The 3,3-bis-substituted oxindole derivatives $\mathbf{2 3 3}$ and related spiro analogues were prepared by alkylation of an $N$-acetyl oxindole 229, deacetylation of $\mathbf{2 3 0}$ to $231, N$-alkylation with benzyl bromoacetate, and final hydrogenation (Scheme 71). ${ }^{96}$ 

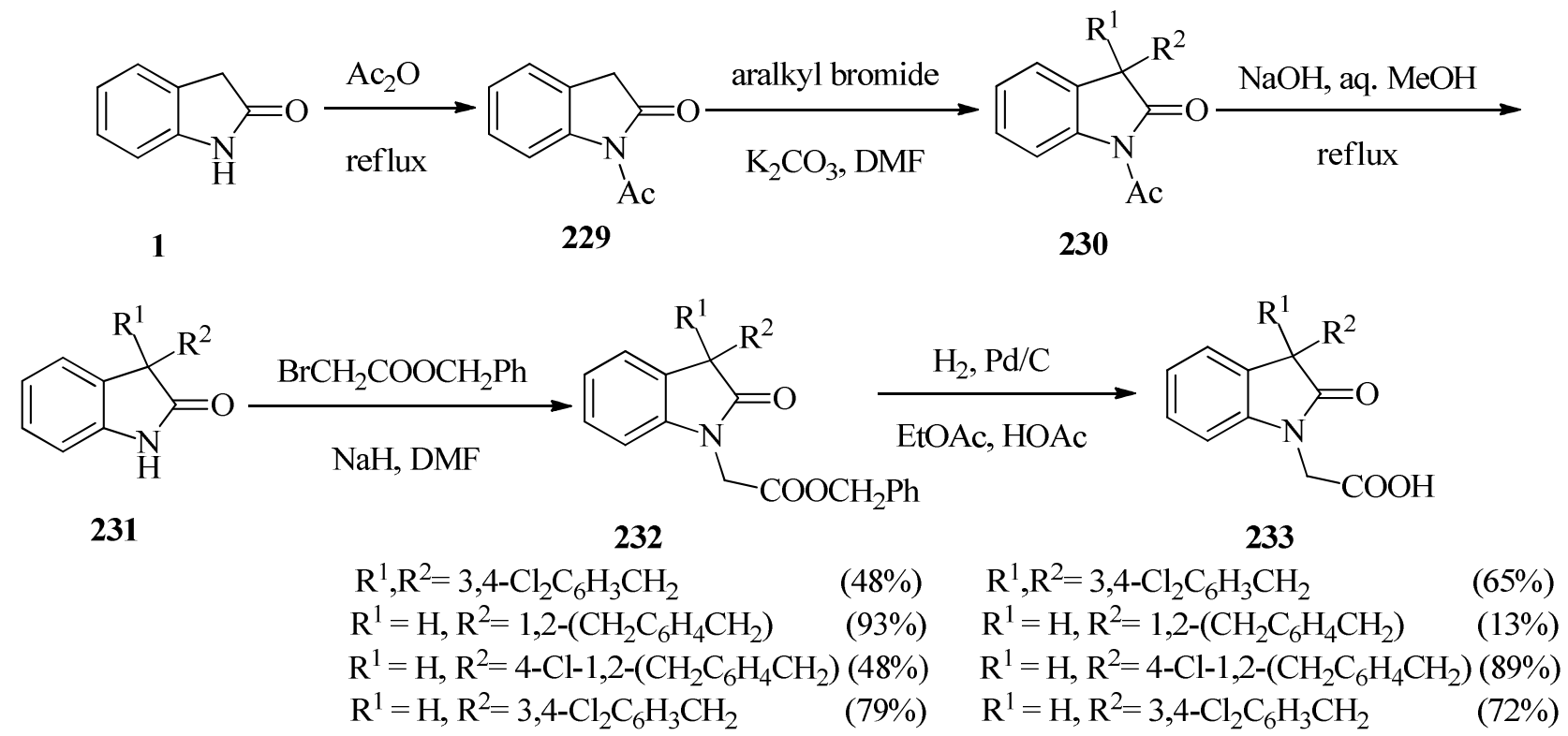

\section{Scheme 71}

Similarly, the 3-monoalkylated oxindole acids 236 were prepared as shown in Scheme 72. Condensation of oxindole with aldehydes followed by alkylation of the intermediate alkylidenes 234 and hydrogenation of the esters 235 generated the desired acids. Alternatively, the sodium salt of compound 234 was treated with tert-butyl bromoacetate and the product 235 was hydrolyzed with trifluoroacetic acid to give the final acid 237, retaining the double bond. Oxindole derivatives 233, 236, and 237 are in vitro inhibitors of aldose reductase ${ }^{96}$ which is a key component of the procedure $^{97,98}$ in which an increase in the flux of glucose through the polyol pathway is implicated in the development of chronic complications in diabetes. ${ }^{99}$

In another study, compound 238 was synthesized via exhaustive methylation of oxindole. Treatment of $\mathbf{2 3 8}$ with dibenzoyl peroxide followed by $\mathrm{NaOH}$ and $\mathrm{NH}_{3}$ in methanol, provided the desired product 239 in a remarkable yield (Scheme 73). ${ }^{100}$ 

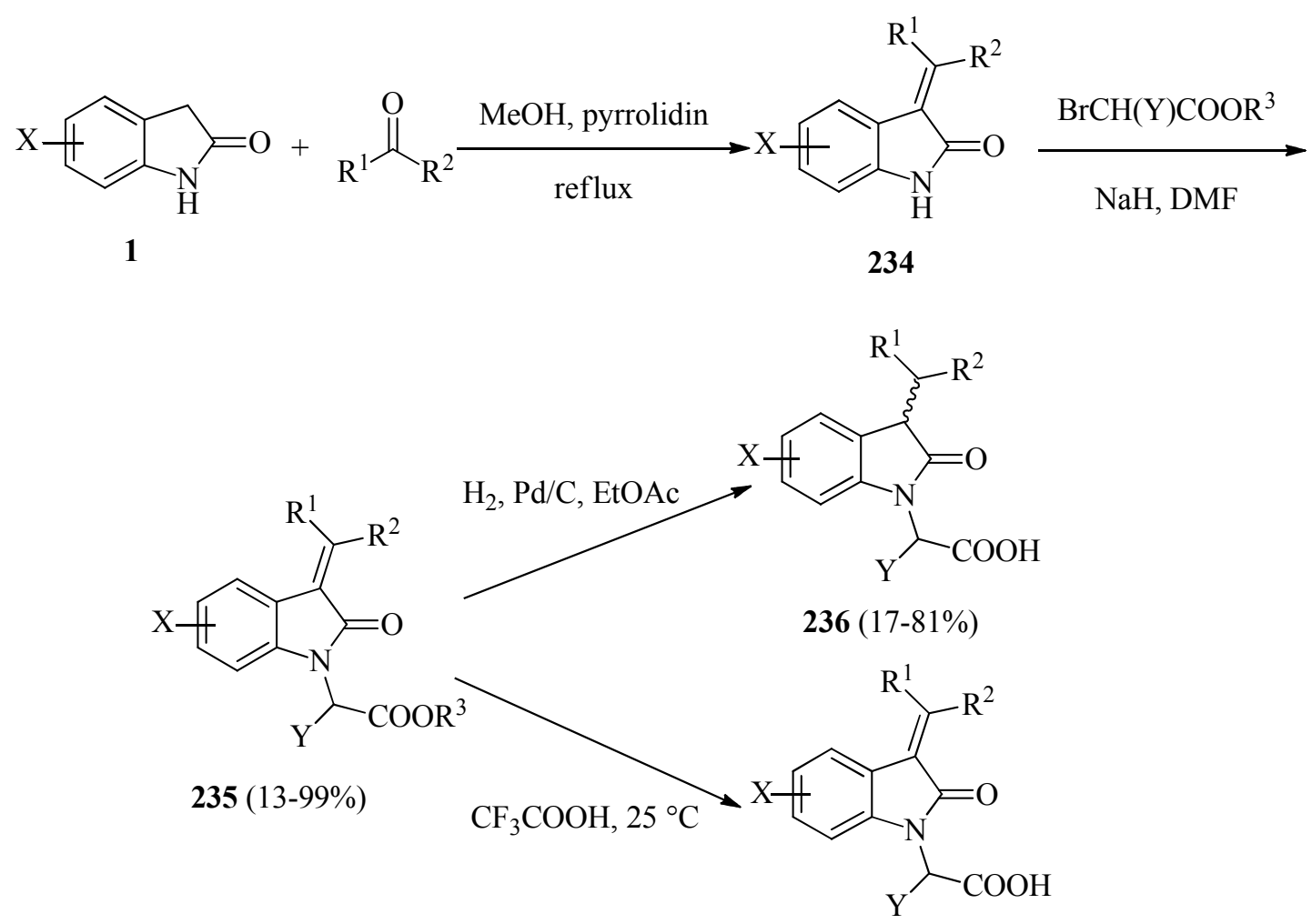

$237(31-76 \%)$

$\mathrm{X}=\mathrm{H}, 5-\mathrm{Cl}, 6-\mathrm{F}, 5,6-\mathrm{F}_{2}, 5-\mathrm{OMe}, 5,6-(\mathrm{OMe})_{2}$

$\mathrm{R}^{1}=\mathrm{R}^{2}=$ cis-3,4- $\mathrm{Cl}_{2} \mathrm{C}_{6} \mathrm{H}_{3} \mathrm{CH}=$, trans-3,4- $\mathrm{Cl}_{2} \mathrm{C}_{6} \mathrm{H}_{3} \mathrm{CH}=, 3,4-\mathrm{Cl}_{2} \mathrm{C}_{6} \mathrm{H}_{3} \mathrm{CH}=, 3,4-\mathrm{Cl}_{2} \mathrm{C}_{6} \mathrm{H}_{3} \mathrm{CMe}=$, 2-benzothiazolyl $\mathrm{Y}=\mathrm{H}, \mathrm{Me}$

\section{Scheme 72}

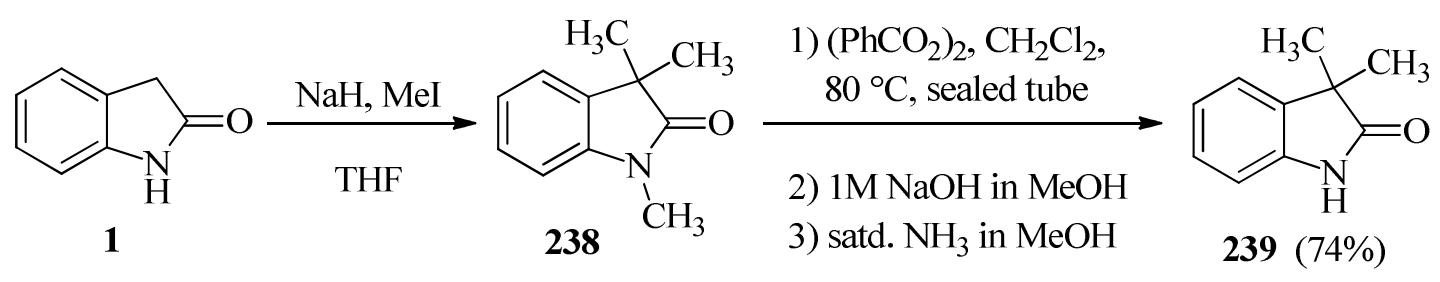

\section{Scheme 73}

A racemic synthesis of 1-(3-amino-1-phenylpropyl)indolin-2-ones 243 was developed by McComas and coworkers. Alkylation of oxindole at the 3-position provided 239 followed by $\mathrm{N}$ alkylation with benzyl bromide to generate compound 240. Installation of an ethanol side chain was accomplished by treatment with n-BuLi and (2-bromo-ethoxy)-t-butyl-dimethyl-silane followed by removal of the silyl group with tetra-n-butylammonium fluoride (TBAF). At this stage the racemic mixture of alcohols was resolved by preparative chiral HPLC to give enantiomers 241 and 242. Alcohol 242 was then converted to the tosylate which was displaced with methylamine to give $(R)$ (3-amino-1-phenylpropyl)indolin-2-one $\mathbf{2 4 3}$ (Scheme 74). ${ }^{101}$ 


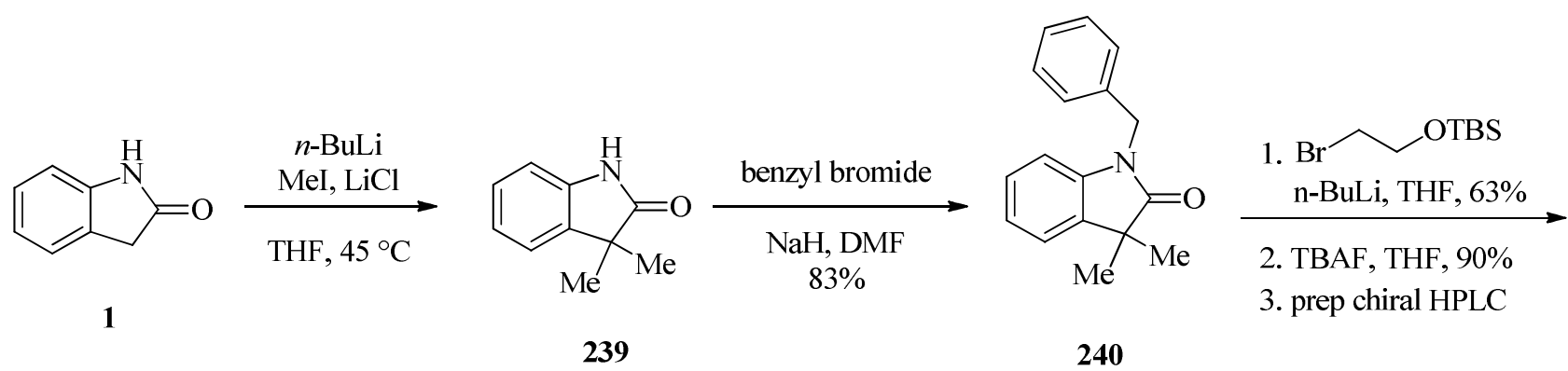<smiles>CC1(C)C(=O)N([C@H](CCO)c2ccccc2)c2ccccc21</smiles>

241<smiles>CC1(C)C(=O)N([C@H](CCO)c2ccccc2)c2ccccc21</smiles>

242

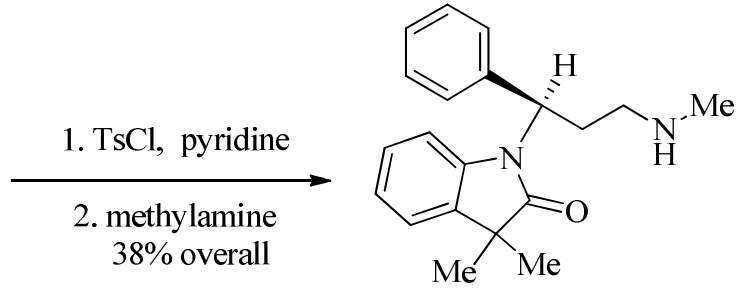

$243(R)$

\section{Scheme 74}

\subsection{Carbonyl group and nitrogen atom}

Simig and coworkers synthesized 1,3-di[alkoxy(aryloxy)carbonyl]-2-oxo-2,3-dihydroindoles 248, 249 and 251 which are very important compounds as starting materials in medicinal chemistry. Different oxindoles were treated with chloroformic acid esters and triethylamine affording $N, O$ diacylated derivatives $\mathbf{2 4 4}$. The $O$-acyl moiety was removed by reaction with ammonium carbonate to give $N$-[alkoxy(or aryloxy)carbonyl]oxindoles 245 in good yields. The reaction of the $N$-acylated derivatives with chloroformic acid esters and triethylamine in THF afforded mixed $N, O$-diacylated derivatives 246. Treatment of $\mathbf{2 4 6}$ and $\mathbf{2 4 4}$ with one equivalent of DMAP in DMF followed by addition of water gave the $N, C(3)$-diacylated dimethylaminopyridinium enolate 247 and 250. Finally, the acidic treatment of these enolates resulted in the conjugated acids 248, 249 and 251 (Scheme 75). ${ }^{102}$

An efficient procedure for the preparation of tryptanthrine antibiotic $\mathbf{2 5 5}$ has been studied. The reaction of oxindole- $\mathrm{HCl}$ salt with $\mathrm{POCl}_{3}$ followed by cyclization with methyl anthranilate 252 afforded the corresponding quinazolinone 253. Subsequent two-step conversion of 253 prepared tryptanthrine $\mathbf{2 5 5}$ in $\mathbf{7 6 \%}$ yield (Scheme 76). ${ }^{103}$ 

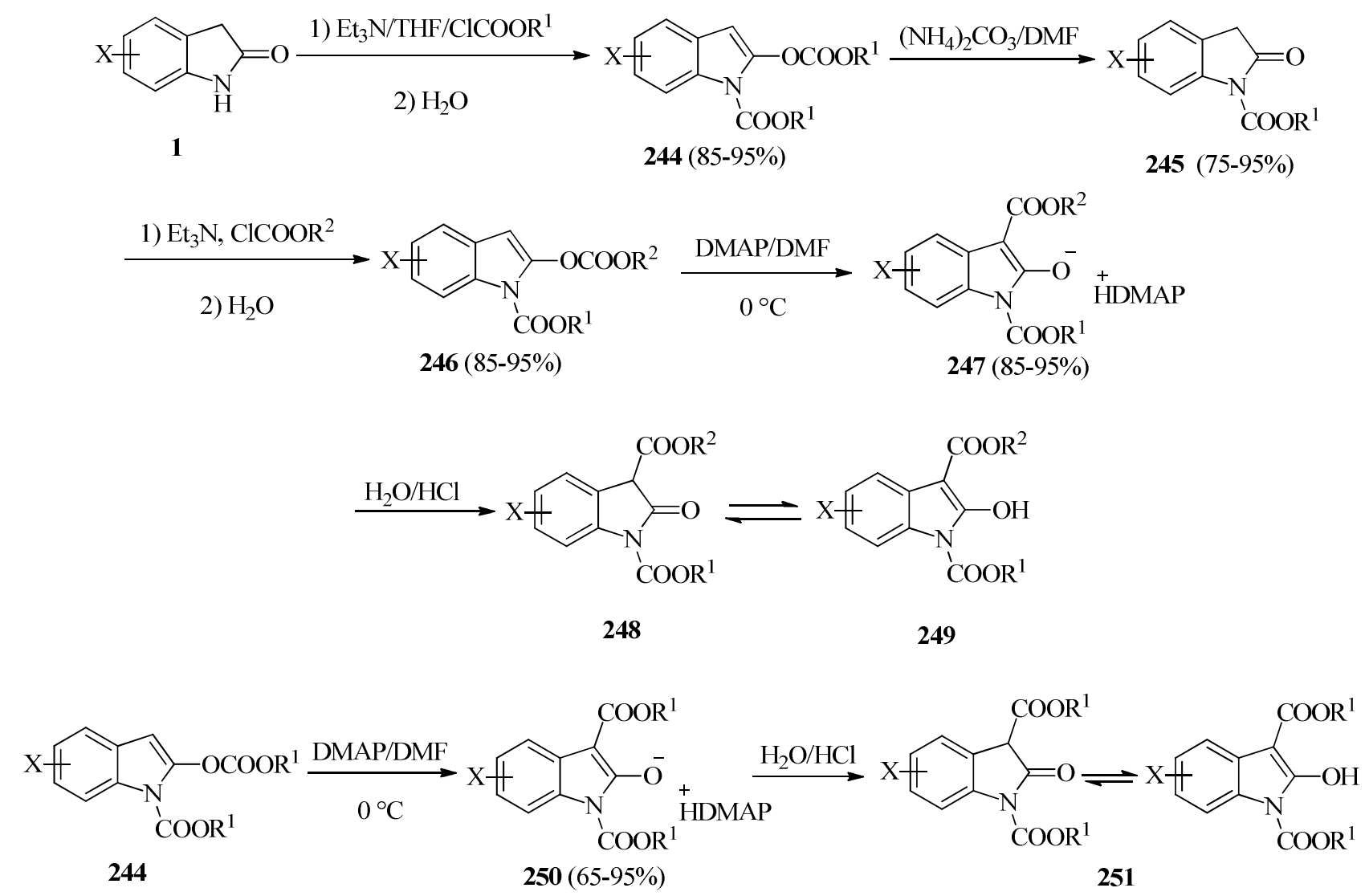

$\mathrm{X}=\mathrm{H}, 5-\mathrm{Cl}, 6-\mathrm{Cl}, 5-\mathrm{NO}_{2} ; \quad \mathrm{R}^{1}=\mathrm{Me}, \mathrm{Et}, \mathrm{Ph}, \mathrm{CH}_{2} \mathrm{Ph}$

$\mathrm{R}^{1} / \mathrm{R}^{2}=\mathrm{Ph} / \mathrm{Me}, \mathrm{Ph} / \mathrm{Et}, \mathrm{Ph} / \mathrm{CH}_{2} \mathrm{Ph}, \mathrm{Me} / \mathrm{Ph}, \mathrm{Et} / \mathrm{Ph}, \mathrm{CH}_{2} \mathrm{Ph} / \mathrm{Ph}, \mathrm{Et} / \mathrm{CH}_{2} \mathrm{Ph}, \mathrm{CH}_{2} \mathrm{Ph} / \mathrm{Et}$

\section{Scheme 75}
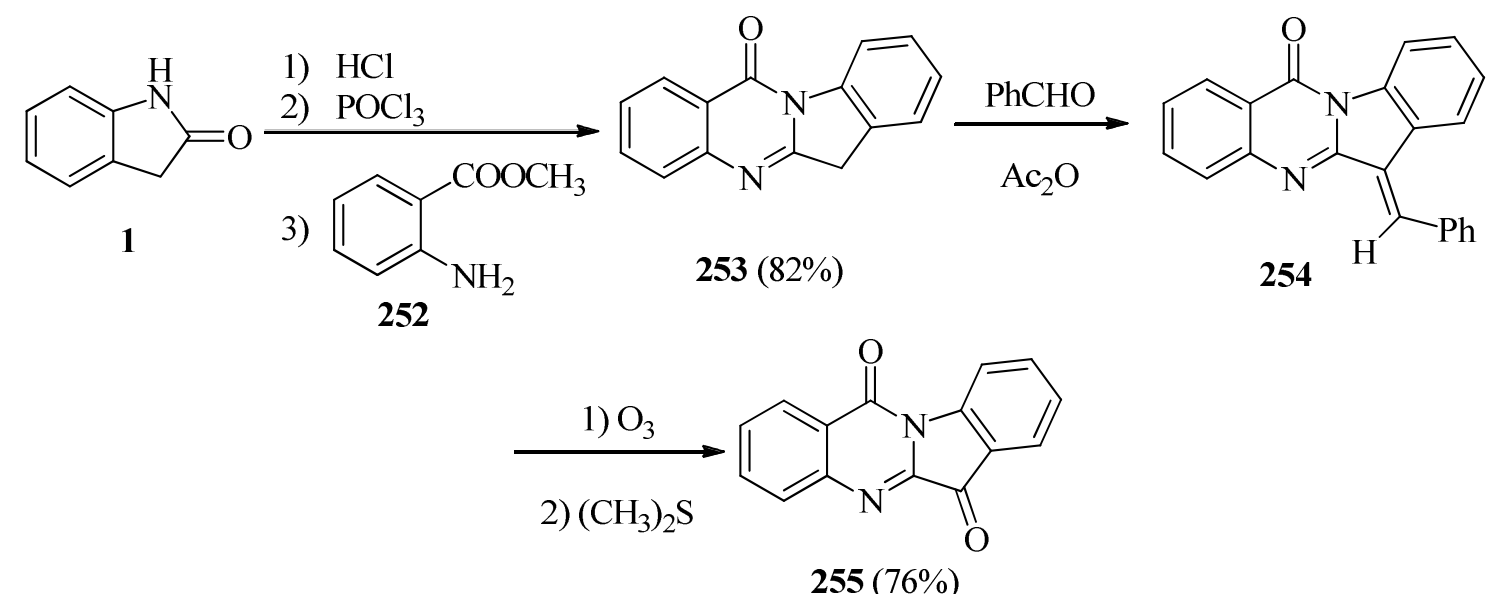

\section{Scheme 76}




\subsection{C-3 atom and aromatic ring}

A series of 3,3-disubstituted-5-aryloxindoles $\mathbf{2 5 8}$ has been synthesized and evaluated for progesterone receptor $(\mathrm{PR})$ antagonist activity. Treatment of oxindole with $\mathrm{n}-\mathrm{BuLi}$ in the presence of TMEDA, followed by quenching the resulting anion with the corresponding alkyl iodide afforded the substituted oxindoles $\mathbf{2 5 6}$. Reaction of $\mathbf{2 5 6}$ with bromine and sodium acetate in acetic acid yielded the bromide derivatives 257. Finally, a Suzuki coupling between the compound 257 and a phenylboronic acid prepared the desired products $\mathbf{2 5 8}$ (Scheme 77). ${ }^{104}$
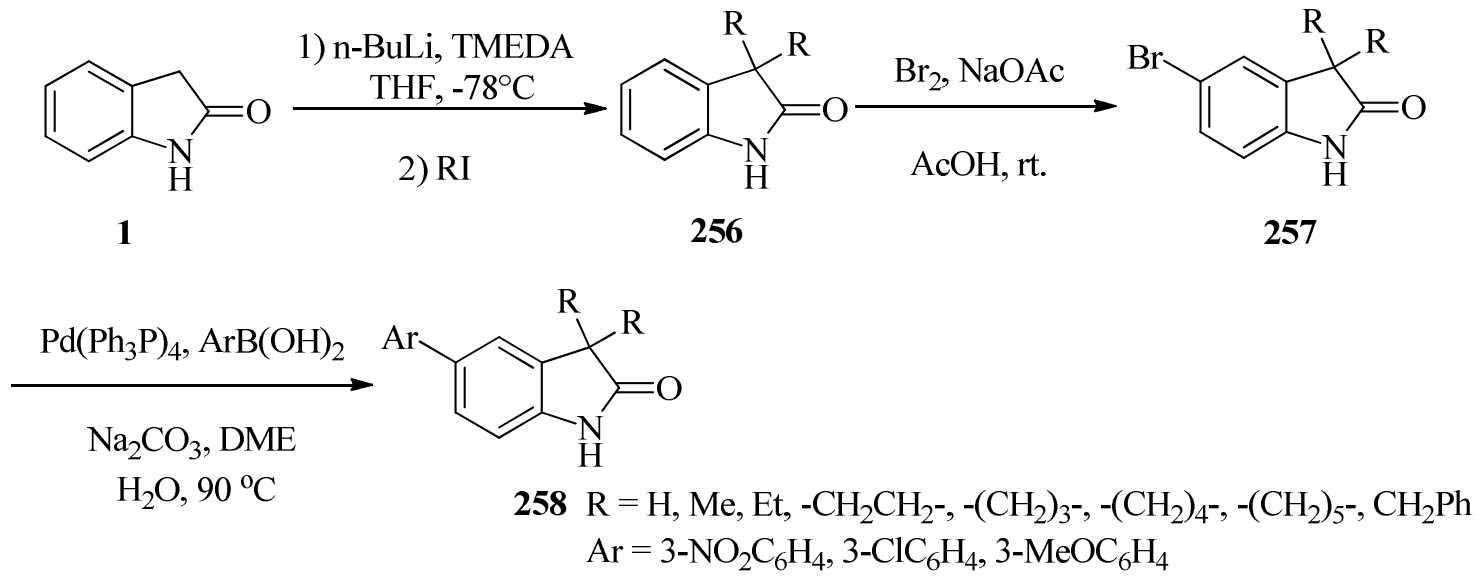

\section{Scheme 77}

\subsection{Participation of three sites in reaction}

One-pot multiple acylation of oxindole was performed using acyl anhydride and catalytic amount of DMAP that resulted in the formation of triacetylated product 259. Subsequently, an enzymeassisted deacetylation resulted in the chemoselective deprotection of the acetoxy group to produce 1,3-diacetyl-2-hydroxyindoles 260 (Scheme 78). ${ }^{105,106}$<smiles>[R]c1ccc2c(c1)CC(=O)N2</smiles>

1<smiles>CC(=O)OC(C)=O</smiles>

$259(76-93 \%)$<smiles>CCCCO</smiles>

$1-4 \mathrm{~h}$

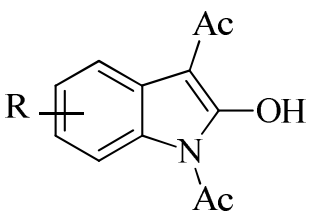

260

$\mathrm{R}=5-\mathrm{NO}_{2}, 5-\mathrm{F}, 5-\mathrm{Br}, 5-\mathrm{Me}, 5-\mathrm{Cl}, 6-\mathrm{Cl}, 7-\mathrm{Cl}$

\section{Scheme 78}

\subsection{Vilsmeier reactions of oxindole}

Vilsmeier chloroformylation of oxindole with $\mathrm{POCl}_{3}, \mathrm{DMF}$, and pyridine provided 2-chloro-3formylindole 261, methylation of which resulted in compound 262. Treatment of 262 with thallium(III) trifluoroacetate in trifluoroacetic acid (TFA) and iodination with iodine and copper 
iodide yielded $\mathrm{N}$-methyl-3-formyl-2-chloro-4-iodoindole 263. Refluxing 263 with hexamethylditin in the presence of $\mathrm{PdCl}_{2}\left(\mathrm{PPh}_{3}\right)_{2}$ or $\mathrm{Pd}\left(\mathrm{PPh}_{3}\right)_{4}$ as catalyst, iodine-tin exchange was achieved to give compound 264. The final step to the desired indole-lead (IV) reagent was the transformation of $\mathbf{2 6 4}$ to 265 by tin-lead exchange. Compound 264 was reacted with lead tetraacetate and catalytic mercury (II) but none of the desired indolelead triacetate was formed (Scheme 79). ${ }^{107}$<smiles>Cn1c(Cl)c(C=O)c2cc(C(N)(N)C(F)(F)F)ccc21</smiles>

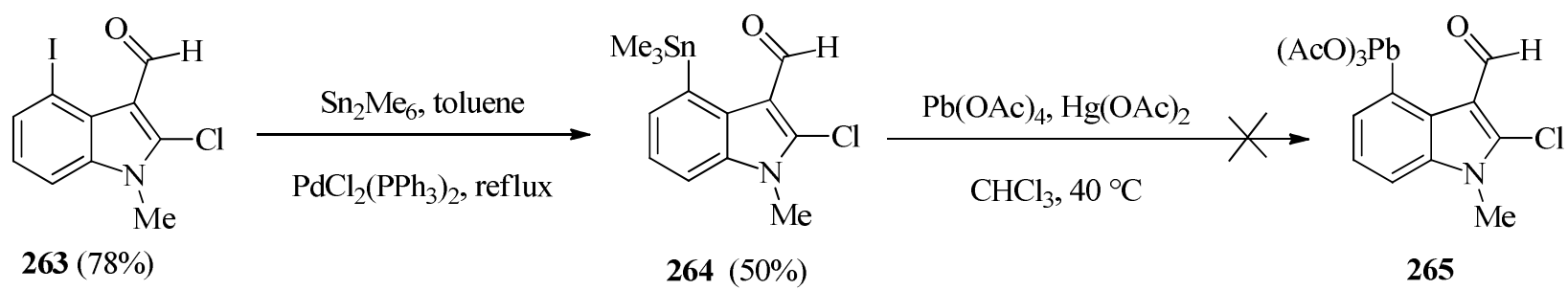

\section{Scheme 79}

Thienodolin 266 was shown to have both growth promoting and inhibiting activities in rice seedling. ${ }^{108}$ Olesen et al. have synthesized methyl thieno[2,3-b]indolecarboxylaye $\mathbf{2 7 0}$ form it's $N$ benzyl derivative 268 by debenzylation with aluminium trichloride in toluene, and then compound $\mathbf{2 7 0}$ was saponified and decarboxylated by heating in morpholine to give thieno[2,3-b]indole $\mathbf{2 7 1}{ }^{109}$
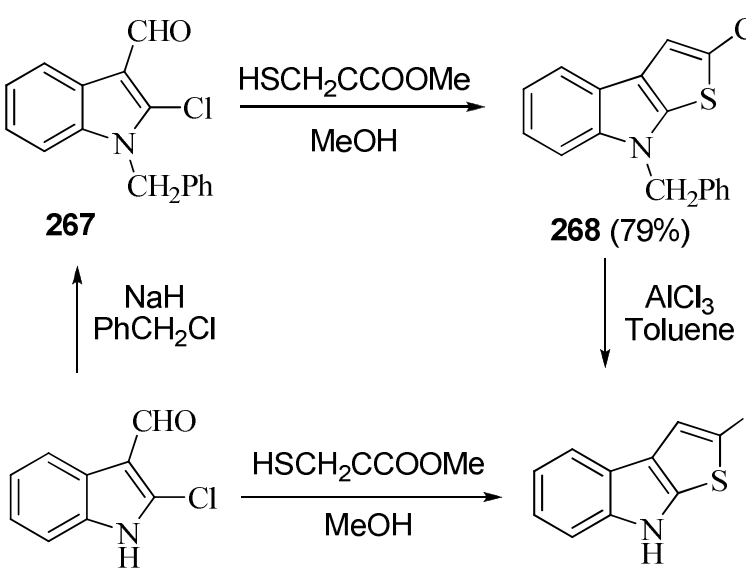

261

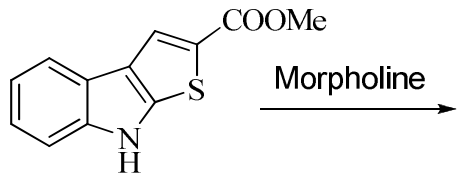

$270(38 \%)$
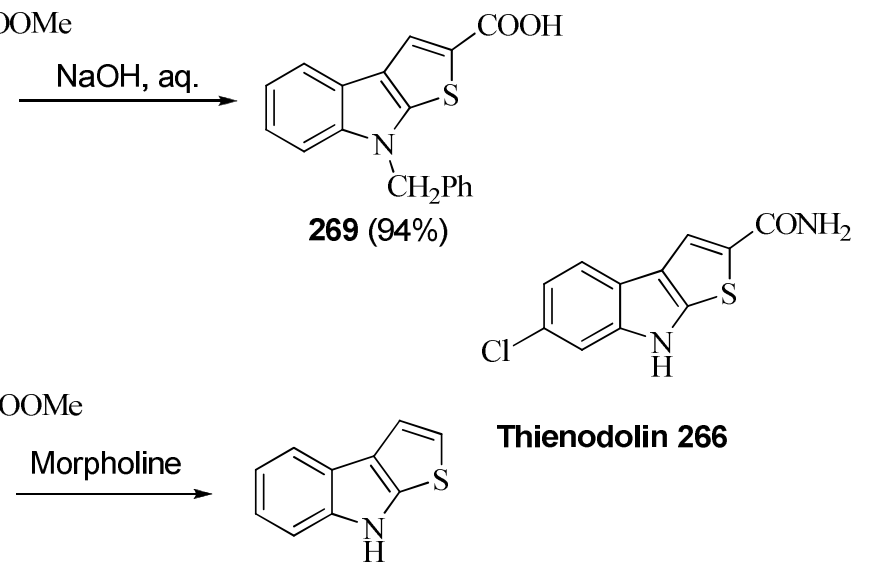

Thienodolin 266

\section{Scheme 80}

Engqvist et al. reported a total synthesis of the alkaloid thienodolin $\mathbf{2 6 6}$ and its derivatives in three steps from the corresponding oxindoles. They were achieved through an initial Vilsmeier 
reaction followed by protection at the indole nitrogen to give $\mathbf{2 7 3}$, creation of the fused thiophene ring by nucleophilic substitution at the 2-position and an intramolecular cyclization using mercaptoacetamide (Scheme 81). ${ }^{110}$
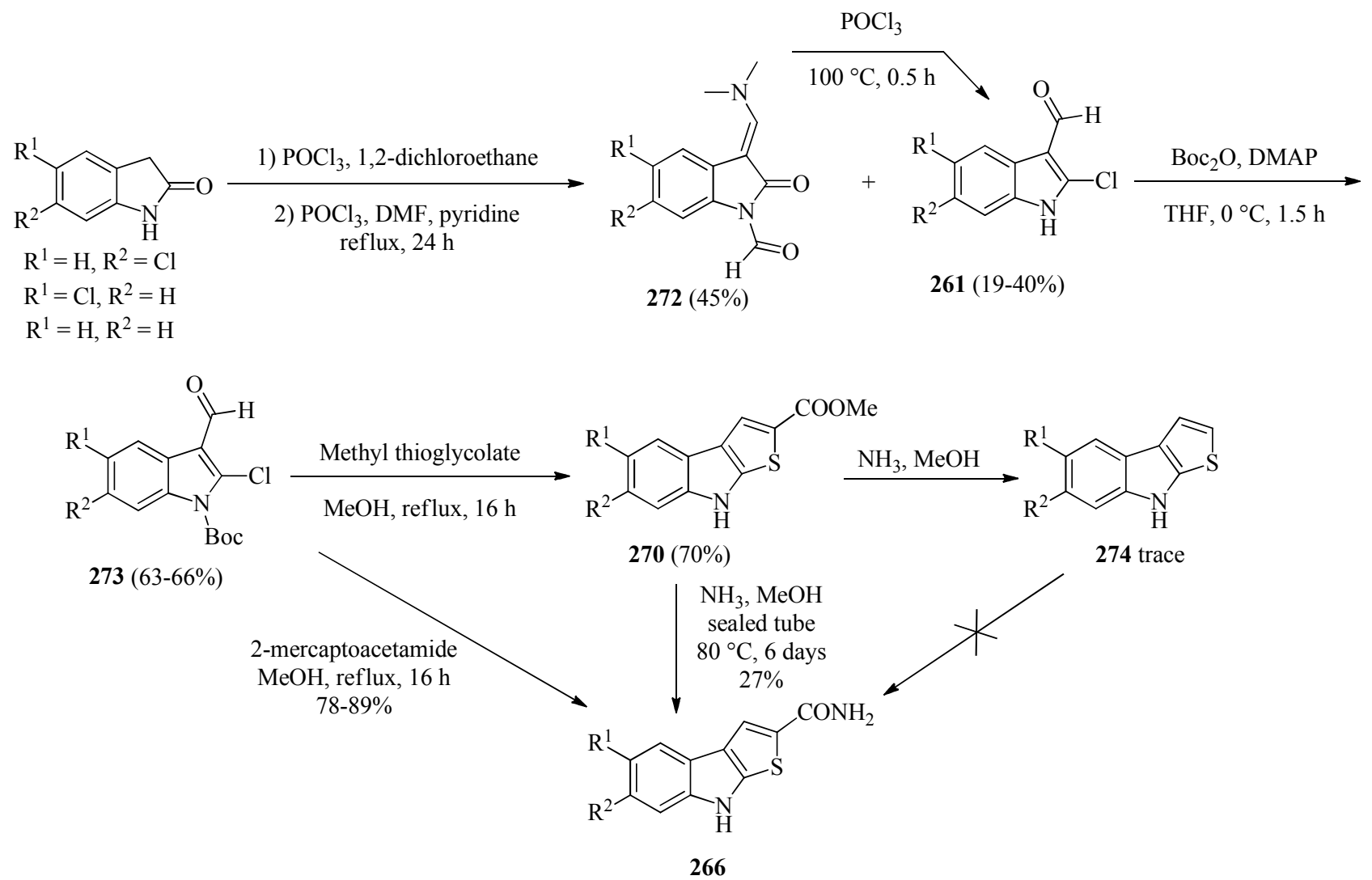

\section{Scheme 81}

Pedras and Jha synthesized the phytoalexin wasalexins 276 using the formylation and amination of oxindole. Oxindole has also been formylated via Vilsmeier reagent to afford brassilexin analogues 274. Aqueous ammonia work-up procedure was shown to afford the desired products in reasonable yields (Scheme 82). ${ }^{111}$ Phytoalexins are secondary metabolites biosynthesized de novo by plants in response to various forms of stress including pathogen attack. $^{112,113}$

Oxindole on treatment with Vilsmeier reagent afforded the key $\beta$-haloaldehyde intermediate 261. The Boc-protected indole 273 underwent nucleophilic substitution at C-2 by diethylamine to give 280. Treatment of the tertiary amine $\mathbf{2 8 0}$ with nitrile afforded the indole derivative $\mathbf{2 8 1}$ with an olefinic bond at the $\beta$-position of the tertiary amine group, which is the requirement for the key reaction step. The final $\alpha$-cyclization of the tertiary amine 281 was carried out at $90{ }^{\circ} \mathrm{C}$ using DMF as solvent, which afforded the $\alpha$-carboline 281. (Scheme 83). ${ }^{114} \alpha$-Carbolines have diverse biological activities such as antitumor, ${ }^{115}$ anti-HIV, ${ }^{116,117}$ antiviral, anxiolytic, anti-inflammatory and CNS-stimulating activities. ${ }^{118}$ 

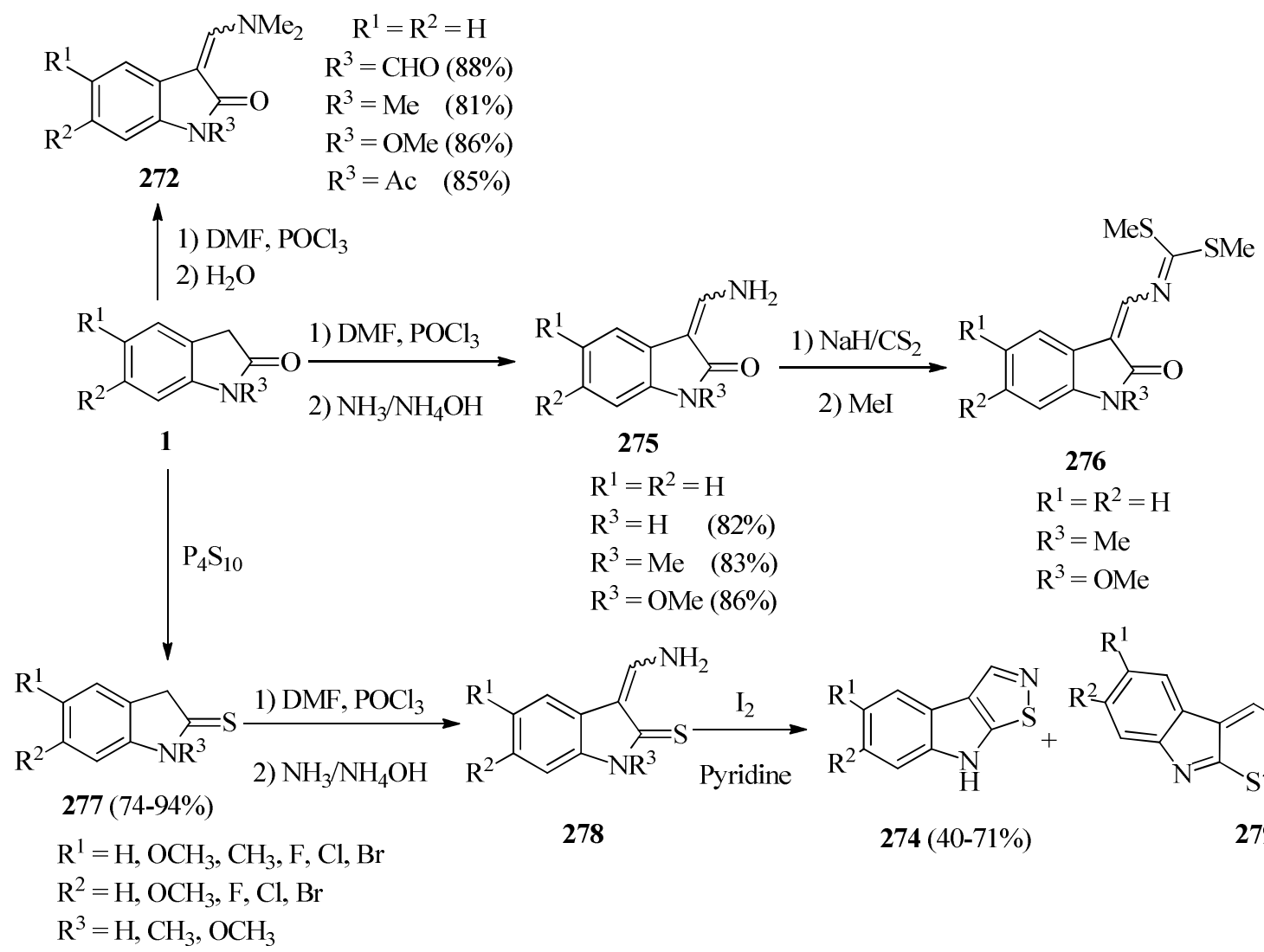
Annelated $\alpha$-carbolines $\mathbf{2 8 4}$ have been synthesized from oxindole using a one-pot threecomponent reaction involving an intra molecular [3+2]-dipolar cycloaddition reaction of azides to nitriles (Scheme 84). ${ }^{119}$<smiles>O=Cc1c(Cl)n(CC(=O)O)c2ccccc12</smiles>

273<smiles>O=Cc1c(Cl)[nH]c2ccccc12</smiles>

261<smiles>CNCc1cccc2c1c(Cl)c(Cl)n2C</smiles>

262

Allyl bromide

PTC, $\mathrm{NaOH}$<smiles>C=CCn1c(Cl)c(C=O)c2ccccc21</smiles>

283<smiles>[R]c1cc2c3ccccc3n([R])c2n2nnnc12</smiles>

284

262,273 and 283

$\mathrm{R}^{1}=\mathrm{Boc}, \mathrm{CH}_{3}$, Allyl

$\mathrm{R}^{2}=\mathrm{CO}_{2} \mathrm{Et}, \mathrm{CN}, \mathrm{CONH}_{2}$ 


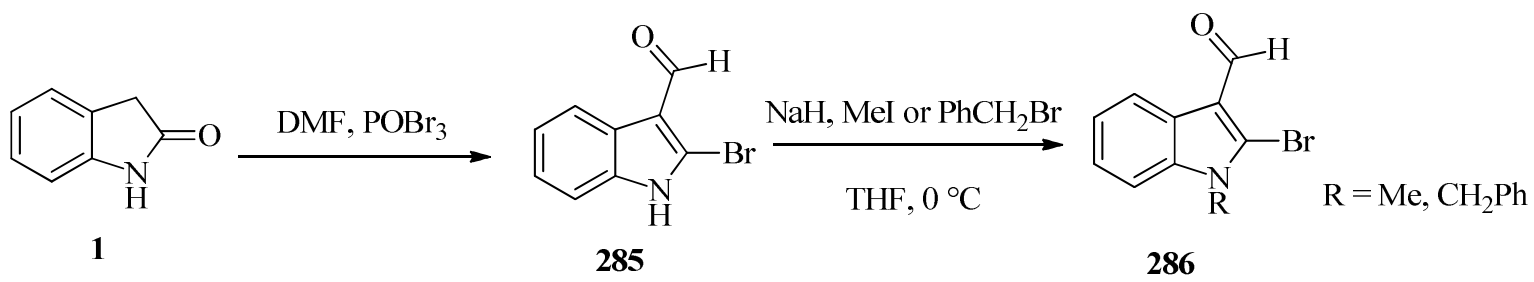<smiles>[R]C#Cc1[nH]c2cc(CC(C)C)ccc2c1C(C)=O</smiles>

\section{Scheme 85}
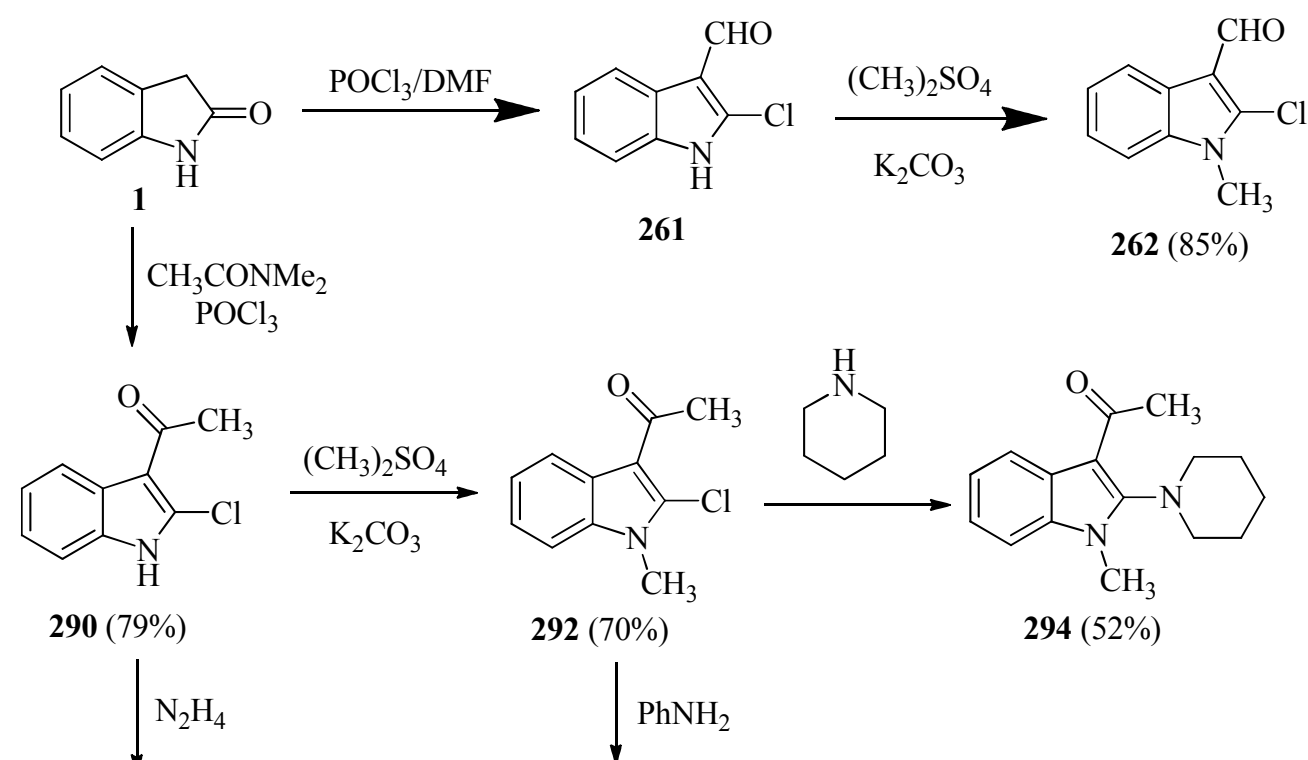
$\mathrm{PhNH}_{2}$<smiles>Cc1n[nH]c2[nH]c3ccccc3c12</smiles>

$291(60 \%)$<smiles>C/C(=N/c1ccccc1)c1c(Nc2ccccc2)n(C)c2ccccc12</smiles>

$293(62 \%)$

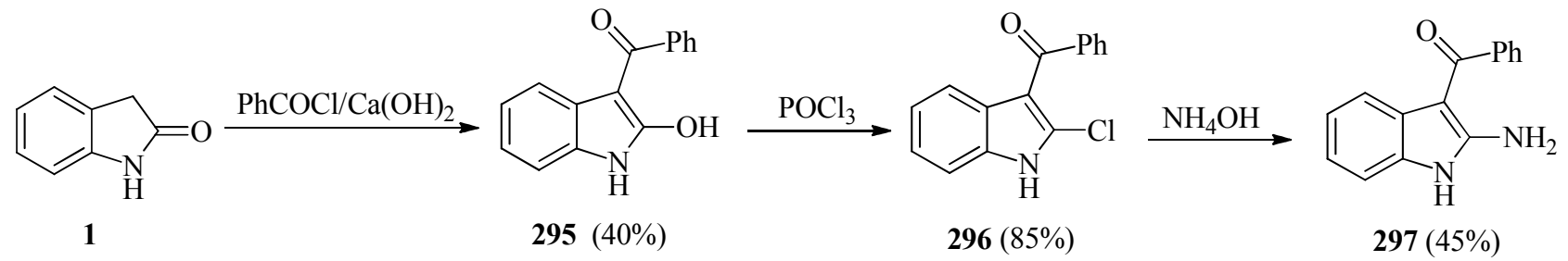

Scheme 86 


\section{One-Pot Reactions}

Bazgir and coworkers investigated the synthesis of new barbiturate salts containing a 2-aminopyridinium moiety by an uncatalyzed three-component condensation of different $\mathrm{C}-\mathrm{H}$ acids, 2aminopyridines 298, and pyrimidine-tetraones 299 in refluxing chloroform. Unlike with 1,3dicarbonyl compounds, it was found that when oxindole $\mathbf{1}$ was used as a $\mathrm{C}-\mathrm{H}$ acid, the desired barbituric salt $\mathbf{3 0 1}$ was not obtained and 5-hydroxy-5-(2-oxoindolin-3-yl)pyrimidine$2,4,6(1 H, 3 H, 5 H)$-trione $\mathbf{3 0 0}$ resulted in $92 \%$ yield (Scheme 87$){ }^{122}$

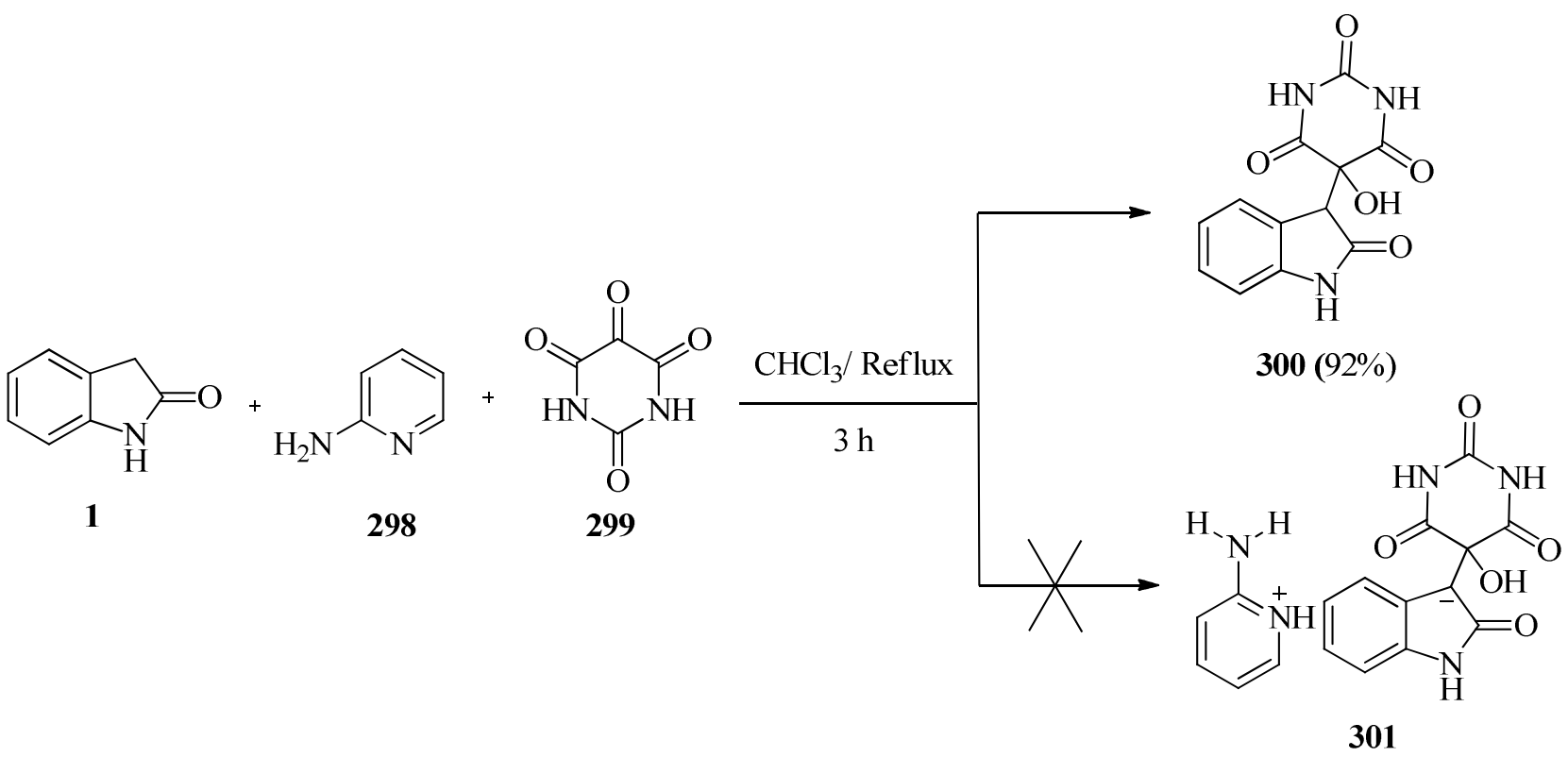

\section{Scheme 87}

A one-pot method for the synthesis of compound 304 was performed via a four-component condensation reaction of oxindole 1, 3-oxo-3-phenylpropanenitrile 302, various hydrazines 303, and aldehydes in the ionic liquid [bmim]Br (Scheme 88). ${ }^{123}$

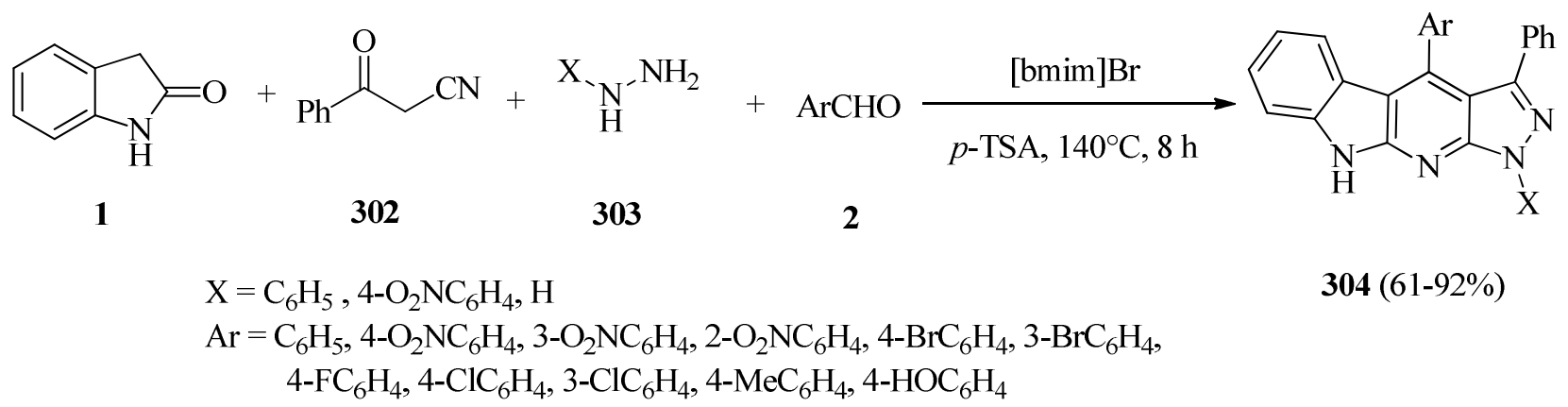

\section{Scheme 88}


The one-pot reaction between oxindole, aldehydes, and Meldrum's acid $\mathbf{3 0 5}$ afforded the useful intermediates $\mathbf{3 0 6}$ for the synthesis of spiro[pyrrolidino-3,3'-oxindoles] $\mathbf{3 0 8}$ related to the natural product horsfiline 309 (Scheme 89 ). ${ }^{124}$

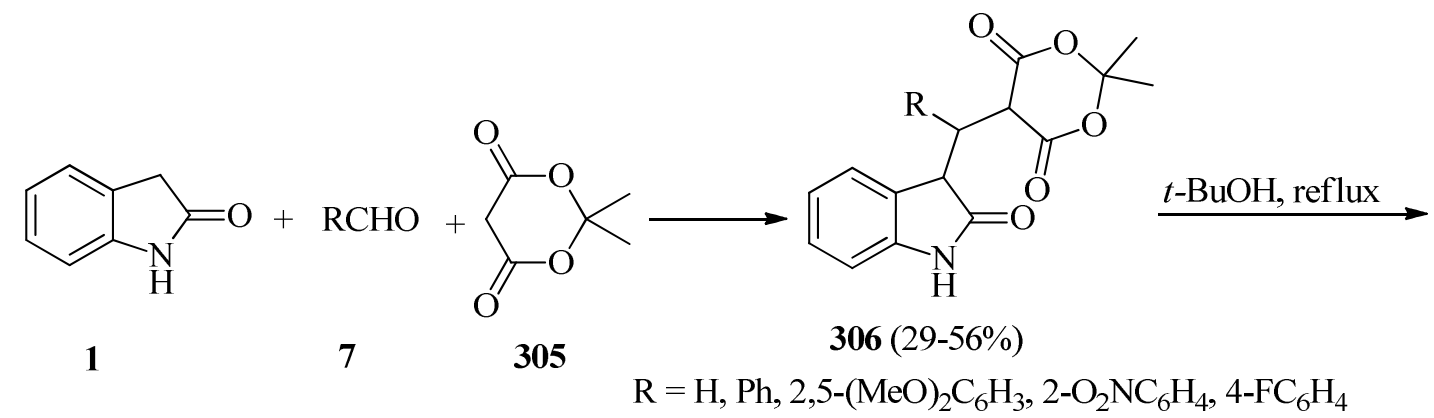<smiles>[R]C(C(C(=O)O)C(=O)OCCC)C1C(=O)Nc2ccccc21</smiles>

$307(45-90 \%)$

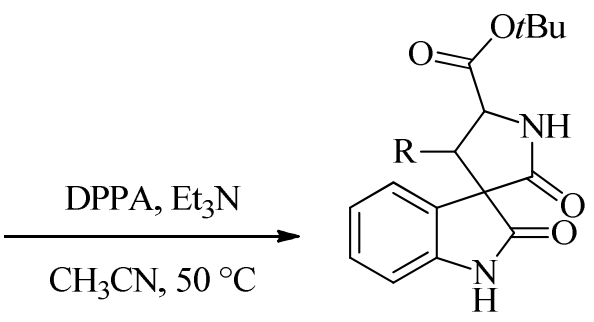

308 (50-74\%)<smiles>COc1ccc2c(c1)C1(CCN(C)C1)C(=O)N2</smiles>

horsfiline 309

$$
\mathrm{R}=\mathrm{H}, \mathrm{Ph}, 2,5-(\mathrm{MeO})_{2} \mathrm{C}_{6} \mathrm{H}_{3} \text {, }
$$

\section{Scheme 89}

A facile one-pot synthesis of 4-substituted 2-amino-4H-chromenes 312 and 314 has been carried out using oxindole 1, malononitrile 311, and different substituted salicylaldehydes 310 or 2hydroxynaphthalene-1-carbaldehyde $\mathbf{3 1 3}$ in the presence of indium trichloride as a catalyst (Scheme 90). ${ }^{125}$

Shaker and coworkers reported their findings in the three-component reaction of oxindole $\mathbf{1}$, ninhydrin 40 and malononitrile $\mathbf{3 1 1}$ in the presence of piperidine under microwave irradiation to give the desired product $\mathbf{3 1 5}$ in high yield (Scheme 91). ${ }^{126}$ 
<smiles>[X]c1cccc(O)c1C=O</smiles>

1

310

311

$\mathrm{X}=\mathrm{H}$, 3-OMe, 3-OEt, 5-Cl, 5- $\mathrm{Br}, 3,5-\mathrm{Br}_{2}, 3,5-\mathrm{Cl}_{2}, 3,5-\mathrm{I}_{2}$.

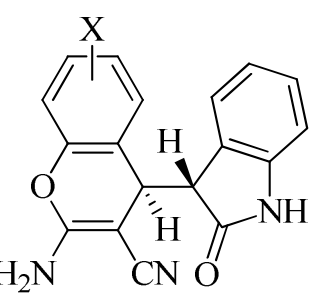

$312(79-85 \%)$<smiles>O=C1Cc2ccccc2N1</smiles>

1<smiles>N#CCC#N</smiles>

313

311<smiles>CCOC(C)(Cl)C1C(C#N)=C(N)Oc2ccc3ccccc3c21</smiles>

$314(81 \%)$

\section{Scheme 90}<smiles>O=C1Cc2ccccc2N1</smiles>

1<smiles>O=C1c2ccccc2C(=O)C1(O)O</smiles>

40<smiles>N#CC1=C(N)Oc2[nH]c3ccccc3c2C12C(=O)c1ccccc1C2=O</smiles>

$315(95 \%)$

\section{Scheme 91}

\section{Domino Reactions}

The stereoselective synthesis of spirooxindole- $4 H$-pyran-2-one derivatives $\mathbf{3 1 8}$ was performed via an NHC-catalyzed (N-heterocyclic carbenes 317) three-component domino reaction of alkynyl aldehydes 316 with oxindole 1 (Scheme 92). ${ }^{127}$ The reaction proceeded smoothly in good yields with good to high diastereoselectivities. 


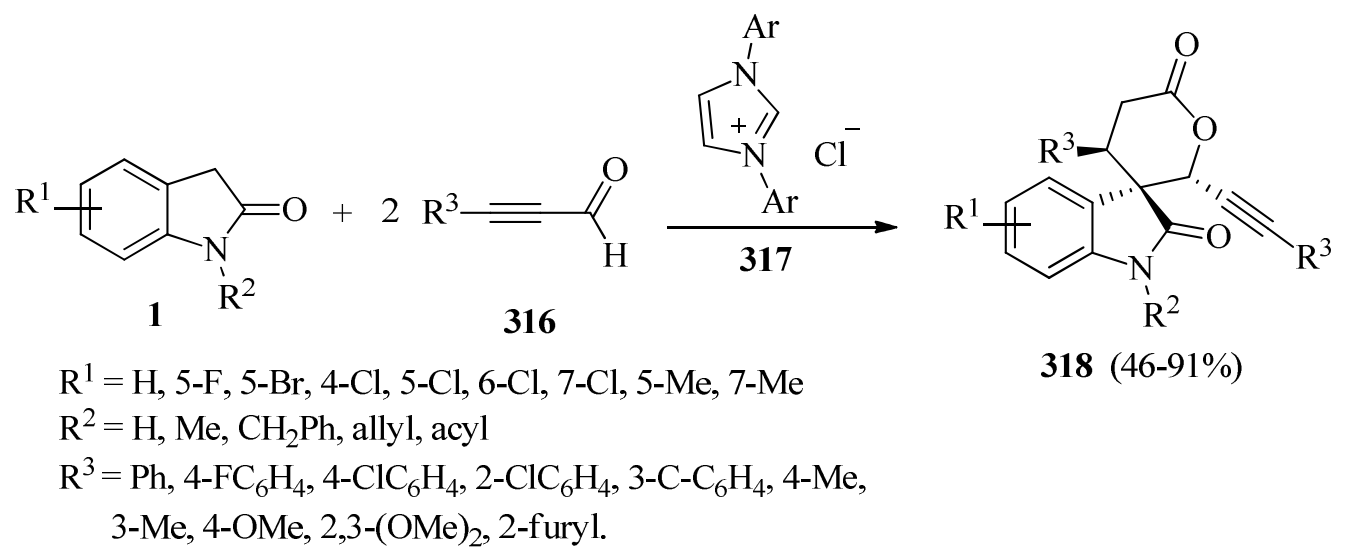

\section{Scheme 92}

\section{Conclusions}

The biological activities of oxindole derivatives make these compounds versatile synthetic targets as well as important structural units in medicinal and synthetic organic chemistry. In this review, we classified oxindole reactions in five classes including reactions on the $\mathrm{C}-3$ atom, nitrogen atom, phenylene ring, carbonyl site, and composition of these reactions. Oxindole as a unique substrate is also a versatile starting material in one-pot and domino reactions.

\section{Acknowledgements}

We are grateful for financial support from the Research Council of Alzahra University.

\section{References}

1. Dreifuss, A. A.; Bastos-Pereira, A. L.; Ávila, T. V.; Soley, B. de S.; Rivero, A. J.; Aguilar, J. L.; Acco, A. J. Ethnopharmacol. 2010, 130, 127-133.

1. http://dx.doi.org/10.1016/j.jep.2010.04.029 PMid:20435132

2. García Giménez, D.; García Prado, E.; Sáenz Rodríguez, T.; Fernández Arche, A.; De La Puerta, R. Planta Med. 2010, 76, 133-136. http://dx.doi.org/10.1055/s-0029-1186048 PMid:19724995

3. Bishop, J. M. Science 1987, 335, 305-311. http://dx.doi.org/10.1126/science.3541204 
4. Guan, H.; Laird, A. D.; Blake, R. A.; Tang, C.; Liang, C. Bioorg. Med. Chem. Lett. 2004, 14, 187-190.

http://dx.doi.org/10.1016/j.bmcl.2003.09.069

5. Plowman, G. D.; Ullrich, A.; Shawver, L. K. Drug News Perspect. 1994, 7, 334-339.

6. Klein, J. E. M. N.; Taylor, R. J. K. Eur. J. Org. Chem. 2011, 6821-6841.

7. Kang, T. H.; Murakami, Y.; Matsumoto, K.; Takayama, H.; Kitajima, M.; Aimi, N.; Watanabe, H. Eur. J. Pharmacol. 2002, 455, 27-34.

http://dx.doi.org/10.1016/S0014-2999(02)02581-5

8. Swensen, A. M.; Herrington, J.; Bugianesi, R. M.; Dai, G.; Haedo, R. J.; Ratliff, K. S.; Smith, M. M.; Warren, V. A.; Arneric, S. P.; Eduljee, C.; Parker, D.; Snutch, T. P.; Hoyt, S. B.;

London, C.; Duffy, J. L.; Kaczorowski, G. J.; McManus, O. B. Mol. Pharmacol. 2012, 81, 488497.

http://dx.doi.org/10.1124/mol.111.075226

PMid:22188924

9. Whatmore, J. L.; Swann, E.; Barraja, P.; Newsome, J. J.; Bunderson, M.; Beall, H. D.; Tooke, J. E.; Moody, C. J. Angiogenesis 2002, 5, 45-51.

http://dx.doi.org/10.1023/A:1021528628524

10. Peddibhotla, S. Curr. Bioactive Compd. 2009, 5, 20-38.

http://dx.doi.org/10.2174/157340709787580900

11. Abbadie, C.; McManus, O. B.; Sun, S. Y.; Bugianesi, R. M.; Dai, G.; Haedo, R. J.; Herrington, J. B.; Kaczorowski, G. J.; Smith, M. M.; Swensen, A. M.; Warren, V. A.; Williams, B.; Arneric, S. P.; Eduljee, C.; Snutch, T. P.; Tringham, E. W.; Jochnowitz, N.; Liang, A.; Euan MacIntyre, D.; McGowan, E.; Mistry, S.; White, V. V.; Hoyt, S. B.; London, C.; Lyons, K. A.; Bunting, P. B.; Volksdorf, S.; Duffy, J. L. J. Pharmacol. Exp. Ther. 2010, 334, 545-55.

http://dx.doi.org/10.1124/jpet.110.166363

PMid:20439438

12. Wahl, A.; Bagard, P. Bull. Soc. Chim. 1909, 5, 1033.

13. Wahl, A.; Bagard, P. Compt. rend. 1909, 148, 716.

14. Wahl, A.; Bagard, P. Compt. rend. 1910, 149, 132.

15. Ölgen, S.; Akaho, E.; Nebioglu, D. Farmaco 2005, 60, 497-506.

http://dx.doi.org/10.1016/j.farmac.2005.01.015

PMid:15927182

16. Kniess, T.; Bergmann, R.; Kuchar, M.; Steinbach, J.; Wuest, F. Bioorg. Med. Chem. 2009, 17, 7732-7742.

http://dx.doi.org/10.1016/j.bmc.2009.09.038

PMid:19822433

17. Zhang, W.; Go, M.-L. Bioorg. Med. Chem. 2009, 17, 2077-2090.

http://dx.doi.org/10.1016/j.bmc.2008.12.052

PMid:19200740

18. Villemin, D.; Martin, B. Synth. Commun. 1998, 28, 3201-3208.

http://dx.doi.org/10.1080/00397919808004422 
19. Gholamzadeh, P.; Ziarani, G. M.; Badiei, A.; Bahrami, Z. Eur. J. Chem. 2012, 3, 279-282. http://dx.doi.org/10.5155/eurjchem.3.3.279-282.630

20. Ding, K.; Wang, G.; Deschamps, J. R.; Parrish, D. A.; Wang, S. Tetrahedron Lett. 2005, 46, 5949-5951.

http://dx.doi.org/10.1016/j.tetlet.2005.06.114

21. Trost, B. M.; Zhang, Y. Chem. Eur. J. 2011, 17, 2916-2922.

http://dx.doi.org/10.1002/chem.201002569

PMid:21290436

22. Spencer, J.; Nielsen, B. V.; Thomas, M. J. K.; Male, L.; Coles, S. J. Acta Crystallogr., Sect. C: Cryst. Struct. Commun. 2011, 67, m245-m248.

http://dx.doi.org/10.1107/S0108270111021536

PMid:21727623

23. Andreani, A.; Leoni, A.; Locatelli, A.; Morigi, R.; Rambaldi, M.; Pietra, C.; Villetti, G. Eur. J. Med. Chem. 2000, 35, 77-82. http://dx.doi.org/10.1016/S0223-5234(00)00103-3

24. Sun, L.; Tran, N.; Tang, F.; App, H.; Hirth, P.; McMahon, G.; Tang, C. J. Med. Chem. 1998, 41, 2588-2603.

http://dx.doi.org/10.1021/jm980123i

PMid:9651163

25. Hoessel, R.; Leclerc, S.; Endicott, J. A.; Nobel, M. E. M.; Lawrie, A.; Tunnah, P.; Leost, M.; Damiens, E.; Marie, D.; Marko, D.; Niederberger, E.; Tang, W.; Eisenbrand, G.; Meijer, L. Nat. Cell. Biol. 1999, 1, 60-67.

http://dx.doi.org/10.1038/9035

PMid:10559866

26. Wee, X. K.; Yeo, W. K.; Zhang, B.; Tan, V. B. C.; Lim, K. M.; Tay, T. E.; Go, M.-L. Bioorg. Med. Chem. 2009, 17, 7562-7571.

http://dx.doi.org/10.1016/j.bmc.2009.09.008

PMid:19783149

27. Sassatelli, M.; Saab, E.; Anizon, F.; Prudhomme, M.; Moreau, P. Tetrahedron Lett. 2004, 45, 4827-4830.

http://dx.doi.org/10.1016/j.tetlet.2004.04.167

28. Gholamzadeh, P.; Ziarani, G. M.; Badiei, A.; Soorki, A. A.; Lashgari, N. Res. Chem. Intermed. 2012, In Press, Doi: 10.1007/s11164-012-0909-y.

http://dx.doi.org/10.1007/s11164-012-0909-y

29. Sassatelli, M.; Bouchikhi, F.; Messaoudi, S.; Anizon, F.; Debiton, E.; Barthomeuf, C.;

Prudhomme, M.; Moreau, P. Eur. J. Med. Chem. 2006, 41, 88-100.

http://dx.doi.org/10.1016/j.ejmech.2005.10.004

PMid:16330129

30. Mei, J.; Graham, K. R.; Stalder, R.; Reynolds, J. R. Org. Lett. 2010, 12, 660-663.

http://dx.doi.org/10.1021/o1902512x

PMid:20099892 
31. Shvets, A.; Kurbatov, S. Chem. Heterocycl. Compd. 2009, 45, 866-867. http://dx.doi.org/10.1007/s10593-009-0344-1

32. Chakrabarty, M.; Mukherji, A.; Arima, S.; Harigaya, Y.; Pilet, G. Monatsh. Chem. 2009, 140, 189-197. http://dx.doi.org/10.1007/s00706-008-0066-6

33. Kniess, T.; Kuchar, M.; Wuest, F. Synth. Commun. 2008, 38, 3017-3022. http://dx.doi.org/10.1080/00397910802044256

34. Andreani, A.; Burnelli, S.; Granaiola, M.; Leoni, A.; Locatelli, A.; Morigi, R.; Rambaldi, M.; Varoli, L.; Calonghi, N.; Cappadone, C.; Farruggia, G.; Zini, M.; Stefanelli, C.; Masotti, L. J. Med. Chem. 2007, 50, 3167-3172.

http://dx.doi.org/10.1021/jm070235m PMid:17559205

35. Sun, L.; Tran, N.; Liang, C.; Tang, F.; Rice, A.; Schreck, R.; Waltz, K.; Shawver, L. K.; McMahon, G.; Tang, C. J. Med. Chem. 1999, 42, 5120-5130. http://dx.doi.org/10.1021/jm9904295

36. Shih, M.-H.; Yeh, M.-Y. Tetrahedron 2003, 59, 4103-4111. http://dx.doi.org/10.1016/S0040-4020(03)00574-X

37. Takaya, H.; Ito, M.; Murahashi, S.-I. J. Am. Chem. Soc. 2009, 131, 10824-10825. http://dx.doi.org/10.1021/ja9036669 PMid:19606857

38. Bartsch, H.; Eiden, F.; Buchborn, H. Arch. Pharm. 1982, 315, 481-490. http://dx.doi.org/10.1002/ardp.19823150602

39. Engqvist, R.; Bergman, J. Tetrahedron 2003, 59, 9649-9653. http://dx.doi.org/10.1016/j.tet.2003.09.084

40. Beccalli, E. M.; Marchesini, A. Synth. Commun. 1993, 23, 2945-2955. http://dx.doi.org/10.1080/00397919308011136

41. M. Beccalli, E.; Marchesini, A.; Pilati, T. Tetrahedron 1994, 50, 12697-12712.

42. Trost, B. M.; Stiles, D. T. Org. Lett. 2007, 9, 2763-2766. http://dx.doi.org/10.1021/ol070971k PMid:17592853

43. Kende, A.; Hodges, J. Synth. Commun. 1982, 12, 1-10. http://dx.doi.org/10.1080/00397918208080058

44. Kende, A. S.; Koch, K.; Smith, C. A. J. Am. Chem. Soc. 1988, 110, 2210-2218. http://dx.doi.org/10.1021/ja00215a034

45. Fuchs, J. R.; Funk, R. L. Org. Lett. 2005, 7, 677-680. http://dx.doi.org/10.1021/o1047532v PMid:15704923

46. Lockman, J. W.; Reeder, M. D.; Robinson, R.; Ormonde, P. A.; Cimbora, D. M.; Williams, B. L.; Willardsen, J. A. Bioorg. Med. Chem. Lett. 2011, 21, 1724-1727. http://dx.doi.org/10.1016/j.bmcl.2011.01.077 PMid:21316225 
47. Bergman, J.; Romero, I. J. Heterocycl. Chem. 2010, 47, 1215-1220. http://dx.doi.org/10.1002/jhet.453

48. Goehring, R. R. Org. Prep. Proced. Int. 1995, 27, 691-694. http://dx.doi.org/10.1080/00304949509458534

49. Vachal, P.; Miao, S.; Pierce, J. M.; Guiadeen, D.; Colandrea, V. J.; Wyvratt, M. J.; Salowe, S. P.; Sonatore, L. M.; Milligan, J. A.; Hajdu, R.; Gollapudi, A.; Keohane, C. A.; Lingham, R. B.; Mandala, S. M.; DeMartino, J. A.; Tong, X.; Wolff, M.; Steinhuebel, D.; Kieczykowski, G. R.; Fleitz, F. J.; Chapman, K.; Athanasopoulos, J.; Adam, G.; Akyuz, C. D.; Jena, D. K.; Lusen, J. W.; Meng, J.; Stein, B. D.; Xia, L.; Sherer, E. C.; Hale, J. J. J. Med. Chem. 2012, 55, $2945-$ 2959.

http://dx.doi.org/10.1021/jm201542d PMid:22364528

50. Jensen, T.; Madsen, R. J. Org. Chem. 2009, 74, 3990-3992. http://dx.doi.org/10.1021/jo900341w PMid:19371090

51. Grigg, R.; Whitney, S.; Sridharan, V.; Keep, A.; Derrick, A. Tetrahedron 2009, 65, 4375-4383. http://dx.doi.org/10.1016/j.tet.2009.03.065

52. Liu, G.; Huang, T.; Zhang, Y.; Liang, X.; Li, Y.; Li, H. Catal. Commun. 2011, 12, 655-659. http://dx.doi.org/10.1016/j.catcom.2010.12.021

53. Dlinnykh, I. V.; Golubeva, G. A.; Leshcheva, I. F.; Nesterov, V. V.; Antipin, M. Y.; Sviridova, L. A. Chem. Heterocycl. Compd. 2004, 40, 1142-1149. http://dx.doi.org/10.1023/B:COHC.0000048286.22570.9f

54. Companyo, X.; Zea, A.; Alba, A.-N. R.; Mazzanti, A.; Moyano, A.; Rios, R. Chem. Commun. 2010, 46, 6953-6955.

http://dx.doi.org/10.1039/c0cc01522a

PMid:20730196

55. Wang, H.; Chen, M.; Wang, L. Chem. Pharm. Bull. 2007, 55, 1439-1441. http://dx.doi.org/10.1248/cpb.55.1439

56. Wilson, R. M.; Hengge, A. C.; Ataei, A.; Chantarasiri, N. J. Org. Chem. 1990, 55, 193-197. http://dx.doi.org/10.1021/jo00288a032

57. Mahmoud, M. R.; El-Bordany, E. A. A.; Hassan, N. F.; El-Azm, F. S. M. A. Phosphorus, Sulfur Silicon Relat. Elem. 2007, 182, 2507-2521.

http://dx.doi.org/10.1080/10426500701506465

58. Phillips, D. P.; Hudson, A. R.; Nguyen, B.; Lau, T. L.; McNeill, M. H.; Dalgard, J. E.; Chen, J.-H.; Penuliar, R. J.; Miller, T. A.; Zhi, L. Tetrahedron Lett. 2006, 47, 7137-7138. http://dx.doi.org/10.1016/j.tetlet.2006.08.004

59. Rossi, E.; Abbiati, G.; Canevari, V.; Celentano, G.; Magri, E. Synthesis 2006, 299-304. http://dx.doi.org/10.1055/s-2005-918509

60. Trost, B. M.; Stiles, D. T. Org. Lett. 2005, 7, 2117-2120.

http://dx.doi.org/10.1021/o1050395x

PMid:15901148 
61. Shen, L.; Hsung, R. P.; Zhang, Y.; Antoline, J. E.; Zhang, X. Org. Lett. 2005, 7, 3081-3084. http://dx.doi.org/10.1021/o1051094q

PMid:15987210

62. Antonchick, A. P.; Samanta, R.; Kulikov, K.; Lategahn, J. Angew. Chem. Int. Ed. 2011, 50, 8605-8608.

http://dx.doi.org/10.1002/anie.201102984

PMid:21793137

63. Katritzky, A. R.; Yao, G.; Lan, X.; Zhao, X. J. Org. Chem. 1993, 58, 2086-2093. http://dx.doi.org/10.1021/jo00060a025

64. Sakakura, A.; Kawajiri, K.; Ohkubo, T.; Kosugi, Y.; Ishihara, K. J. Am. Chem. Soc. 2007, 129, 14775-14779.

http://dx.doi.org/10.1021/ja075824w

PMid:17983230

65. Berry, D. J.; DiGiovanna, C. V.; Metrick, S. S.; Murugan, R. Arkivoc 2001, (i), 201-226.

66. Rajeswaran, W. G.; Cohen, L. A. Tetrahedron 1998, 54, 11375-11380.

http://dx.doi.org/10.1016/S0040-4020(98)00679-6

67. Akai, S.; Tsujino, T.; Naka, T.; Tanimoto, K.; Kita, Y. Tetrahedron Lett. 2001, 42, 7315-7317. http://dx.doi.org/10.1016/S0040-4039(01)01547-7

68. Gandon, V.; Aubert, C.; Malacriab, M.; Vollhardt, K. P. C. Chem. Commun. 2008, 1599-1601. http://dx.doi.org/10.1039/b716841a

PMid:18354812

69. Altman, R. A.; Hyde, A. M.; Huang, X.; Buchwald, S. L. J. Am. Chem. Soc. 2008, 130, $9613-$ 9620.

http://dx.doi.org/10.1021/ja803179s

PMid:18588302 PMCid:2587375

70. Black, D. St.C.; Rezaie, R. Tetrahedron Lett. 1999, 40, 4251-4254.

http://dx.doi.org/10.1016/S0040-4039(99)00699-1

71. Ghandi, M.; Salahi, S.; Hasani, M. Tetrahedron Lett. 2011, 52, 270-273.

http://dx.doi.org/10.1016/j.tetlet.2010.11.019

72. Shoji, T.; Inoue, Y.; Ito, S. Tetrahedron Lett. 2012, 53, 1493-1496.

http://dx.doi.org/10.1016/j.tetlet.2012.01.044

73. Meragelman, K. M.; West, L. M.; Northcote, P. T.; Pannell, L. K.; McKee, T. C.; Boyd, M. R. J. Org. Chem. 2002, 67, 6671-6678.

http://dx.doi.org/10.1021/jo020120k

74. Wahlström, N.; Bergman, J. Tetrahedron Lett. 2004, 45, 7273-7275.

http://dx.doi.org/10.1016/j.tetlet.2004.08.024

75. Busch-Petersen, J.; Corey, E. J. Org. Lett. 2000, 2, 1641-1643.

http://dx.doi.org/10.1021/ol005964+

PMid:10841499

76. Yamada, S.; Yaguchi, S.; Matsuda, K. Tetrahedron Lett. 2002, 43, 647-651.

http://dx.doi.org/10.1016/S0040-4039(01)02208-0 
77. Sumpter, W. C.; Miller, M.; Hendrick, L. N. J. Am. Chem. Soc. 1945, 67, 1656-1658. http://dx.doi.org/10.1021/ja01226a011

78. Lackey, K.; Cory, M.; Davis, R.; Frye, S. V.; Harris, P. A.; Hunter, R. N.; Jung, D. K.; McDonald, O. B.; McNutt, R. W.; Peel, M. R.; Rutkowske, R. D.; Veal, J. M.; Wood, E. R. Bioorg. Med. Chem. Lett. 2000, 10, 223-226. http://dx.doi.org/10.1016/S0960-894X(99)00668-X

79. Itoh, N.; Sakamoto, T.; Miyazawa, E.; Kikugawa, Y. J. Org. Chem. 2002, 67, 7424-7428. http://dx.doi.org/10.1021/jo0260847

80. Lai, J. Y. Q.; Cox, P. J.; Patel, R.; Sadiq, S.; Aldous, D. J.; Thurairatnam, S.; Smith, K.; Wheeler, D.; Jagpal, S.; Sofia Parveen; Fenton, G.; Harrison, T. K. P.; McCarthy, C.; Bamborough, P. Bioorg. Med. Chem. Lett. 2003, 13, 3111-3114. http://dx.doi.org/10.1016/S0960-894X(03)00658-9

81. Bergman, J.; Engqvist, R.; Stålhandske, C.; Wallberg, H. Tetrahedron 2003, 59, 1033-1048. http://dx.doi.org/10.1016/S0040-4020(02)01647-2

82. Patteux, C.; Levacher, V.; Dupas, G. Org. Lett. 2003, 5, 3061-3063. http://dx.doi.org/10.1021/ol035049z PMid:12916981

83. Friedländer, P. Chem. Ber. 1882, 15, 2572-2575. http://dx.doi.org/10.1002/cber.188201502219

84. McGeachin, S. G. Can. J. Chem. 1966, 44, 2323-2328. http://dx.doi.org/10.1139/v66-348

85. Chuiguk, V. Chem. Heterocycl. Compd. 1973, 9, 656-656. http://dx.doi.org/10.1007/BF00480587

86. Chan, F.; Magnus, P.; McIver, E. G. Tetrahedron Lett. 2000, 41, 835-838. http://dx.doi.org/10.1016/S0040-4039(99)02204-2

87. Fröhner, W.; Monse, B.; Braxmeier, T. M.; Casiraghi, L.; Sahagún, H.; Seneci, P. Org. Lett. 2005, 7, 4573-4576.

http://dx.doi.org/10.1021/ol051550a

PMid:16209482

88. Ginnari-Satriani, L.; Casagrande, V.; Bianco, A.; Ortaggi, G.; Franceschin, M. Org. Biomol. Chem. 2009, 7, 2513-2516.

http://dx.doi.org/10.1039/b904723a

PMid:19503922

89. Huang, A.; Kodanko, J. J.; Overman, L. E. J. Am. Chem. Soc. 2004, 126, 14043-14053. http://dx.doi.org/10.1021/ja046690e PMid:15506768

90. Trost, B. M.; Zhang, Y.; Zhang, T. J. Org. Chem. 2009, 74, 5115-5117. http://dx.doi.org/10.1021/jo900760r PMid:19588998 
91. Robertson, D. W.; Krushinski, J. H.; Beedle, E. E.; Wyss, V.; Pollock, G. D.; Wilson, H.; Kauffman, R. F.; Hayes, J. S. J. Med. Chem. 1986, 29, 1832-1840.

http://dx.doi.org/10.1021/jm00160a006

92. Robertson, D. W.; Krushinski, J. H.; Pollock, G. D.; Wilson, H.; Kauffman, R. F.; Hayes, J. S. J. Med. Chem. 1987, 30, 824-829. http://dx.doi.org/10.1021/jm00388a014

93. Thompson, A. M.; Rewcastle, G. W.; Tercel, M.; Dobrusin, E. M.; Fry, D. W.; Kraker, A. J.; Denny, W. A. J. Med. Chem. 1993, 36, 2459-2469.

http://dx.doi.org/10.1021/jm00069a003

94. Corwin, A. H.; Krieble, R. H. J. Am. Chem. Soc. 1941, 63, 1829-1834. http://dx.doi.org/10.1021/ja01852a010

95. Blanche, E. A.; Maskell, L.; Colucci, M. A.; Whatmore, J. L.; Moody, C. J. Tetrahedron 2009, 65, 4894-4903. http://dx.doi.org/10.1016/j.tet.2009.04.014

96. Howard, H. R.; Sarges, R.; Siegel, T. W.; Beyer, T. A. Eur. J. Org. Chem. 1992, 27, 779-789.

97. Beyer, T. A.; Hutson, N. J. Metab., Clin. Exp. 1986, 35, 1-3.

98. Cheng, H.-M.; González, R. G.; Barnett, P. A.; Aguayo, J. B.; Wolfe, J.; Chylack, L. T. Exp. Eye Res. 1985, 40, 223-229.

http://dx.doi.org/10.1016/0014-4835(85)90007-7

99. Niakan, E.; Harati, Y.; Comstock, J. P. Metabolism 1986, 35, 224-234. http://dx.doi.org/10.1016/0026-0495(86)90205-2

100. Beyersbergen van Henegouwen, W. G.; Fieseler, R. M.; Rutjes, F. P. J. T.; Hiemstra, H. J. Org. Chem. 2000, 65, 8317-8325. http://dx.doi.org/10.1021/jo001119t

101. McComas, C. C.; Vu, A. T.; Mahaney, P. E.; Cohn, S. T.; Fensome, A.; Marella, M. A.; Nogle, L.; Trybulski, E. J.; Ye, F.; Zhang, P.; Alfinito, P.; Bray, J.; Johnston, G.; Koury, E.; Deecher, D. C. Bioorg. Med. Chem. Lett. 2008, 18, 4929-4931. http://dx.doi.org/10.1016/j.bmcl.2008.08.060 PMid:18771916

102. Porcs-Makkay, M.; Volk, B.; Kapiller-Dezsofi, R.; Mezei, T.; Simig, G. Monatsh. Chem. 2004, 135, 697-711. http://dx.doi.org/10.1007/s00706-003-0127-9

103. Lee, E. S.; Park, J.-G.; Jahng, Y. Tetrahedron Lett. 2003, 44, 1883-1886. http://dx.doi.org/10.1016/S0040-4039(03)00080-7

104. Fensome, A.; Bender, R.; Cohen, J.; Collins, M. A.; Mackner, V. A.; Miller, L. L.; Ullrich, J. W.; Winneker, R.; Wrobel, J.; Zhang, P.; Zhangb, Z.; Zhu, Y. Bioorg. Med. Chem. Lett. 2002, 12, 3487-3490. http://dx.doi.org/10.1016/S0960-894X(02)00746-1

105. Jha, M.; Blunt, B. Tetrahedron Lett. 2009, 50, 6044-6047. http://dx.doi.org/10.1016/j.tetlet.2009.08.057 
106. Jha, M.; Chou, T.-Y.; Blunt, B. Tetrahedron 2011, 67, 982-989. http://dx.doi.org/10.1016/j.tet.2010.11.105

107. Deng, H.; Konopelski, J. P. Org. Lett. 2001, 3, 3001-3004. http://dx.doi.org/10.1021/ol016379r PMid:11554828

108. Kanbe, K.; Naganawa, H.; Nakamura, K. T.; Okami, Y.; Takeuchi, T. Biosci. Biotech. Biochem. 1993, 57, 636-637. http://dx.doi.org/10.1271/bbb.57.636

109. Olesen, P. H.; Hansen, J. B.; Engelstoft, M. J. Heterocyclic Chem. 1995, 32, 1641-1642. http://dx.doi.org/10.1002/jhet.5570320540

110. Engqvist, R.; Javaid, A.; Bergman, J. Eur. J. Org. Chem. 2004, 2589-2592.

111. Pedras, M. S. C.; Jha, M. J. Org. Chem. 2005, 70, 1828-1834. http://dx.doi.org/10.1021/jo0479866 PMid:15730307

112. Pedras, M. S. C.; Hossain, M.; Sarwar, M. G.; Montaut, S. Bioorg. Med. Chem. Lett. 2004, 14, 5469-5471.

http://dx.doi.org/10.1016/j.bmcl.2004.09.014

PMid:15482905

113. Soledade, M.; Pedras, C.; Smith, K. C. Phytochemistry 1997, 46, 833-837. http://dx.doi.org/10.1016/S0031-9422(97)00362-2

114. Majumder, S.; Bhuyan, P. Synlett 2011, 173-176.

115. Burstein, H.; Overmoyer, B.; Gelman, R.; Silverman, P.; Savoie, J.; Clarke, K.; Dumadag, L.; Younger, J.; Ivy, P.; Winer, E. Invest. New Drugs 2007, 25, 161-164.

http://dx.doi.org/10.1007/s10637-006-9007-6 PMid:16969707

116. Li, X.; Vince, R. Bioorg. Med. Chem. 2006, 14, 2942-2955.

http://dx.doi.org/10.1016/j.bmc.2005.12.013

PMid:16386908

117.Zhao, G.; Wang, C.; Liu, C.; Lou, H. Mini-Rev. Med. Chem. 2007, 7, 707-725. http://dx.doi.org/10.2174/138955707781024535

PMid:17627583

118. Paolini, L. Sci. Rep. Ist. Super. Sanita 1961, 1, 86.

119. Bhuyan, P.; Majumder, S. Synlett 2011, 1547-1550.

120. Tiano, M.; Belmont, P. J. Org. Chem. 2008, 73, 4101-4109. http://dx.doi.org/10.1021/jo800249f PMid:18459813

121. Monge, A.; Palop, J.; Ramirez, C.; Font, M.; Fernandez-Alvarez, E. Eur. J. Med. Chem. 1991, 26, 179-188. http://dx.doi.org/10.1016/0223-5234(91)90027-K

122. Ahadi, S.; Abaszadeh, M.; Khavasi, H. R.; Bazgir, A. Tetrahedron 2012, 68, 2906-2916. http://dx.doi.org/10.1016/j.tet.2012.01.069 
123. Ghahremanzadeh, R.; Ahadi, S.; Bazgir, A. Tetrahedron Lett. 2009, 50, 7379-7381. http://dx.doi.org/10.1016/j.tetlet.2009.10.077

124. Cochard, F.; Laronze, M.; Prost, É.; Nuzillard, J.-M.; Augé, F.; Petermann, C.; Sigaut, P.; Sapi, J.; Laronze, J.-Y. Eur. J. Org. Chem. 2002, 3481-3490.

http://dx.doi.org/10.1002/1099-0690(200210)2002:20<3481::AID-EJOC3481>3.0.CO;2-C

125. Perumal, P.; Lakshmi, N.; Kiruthika, S. E. Synlett 2011, 1389-1394.

http://dx.doi.org/10.1055/s-0030-1260563

126. Shaker, R. M.; Mahmoud, A. F.; Abdel-Latif, F. F. J. Chin. Chem. Soc. 2005, 52, 563-567.

127. Du, D.; Hu, Z.; Jin, J.; Lu, Y.; Tang, W.; Wang, B.; Lu, T. Org. Lett. 2012, 14, 1274-1277. http://dx.doi.org/10.1021/ol300148f

PMid:22352352

\section{Authors' Biographies}

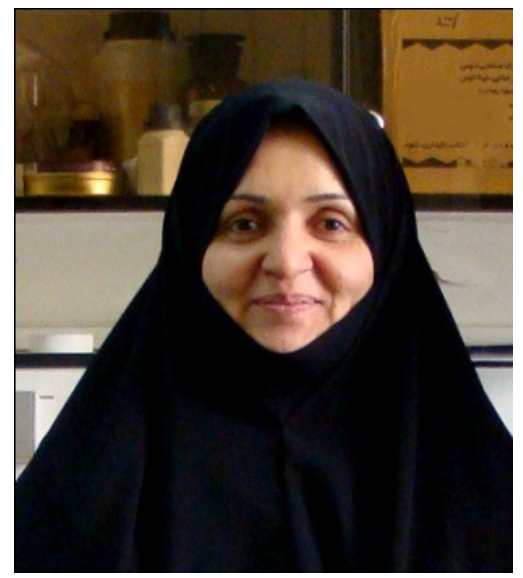

Ghodsi Mohammadi Ziarani was born in Iran, in 1964. She received her BSc. degree in Chemistry from Teacher Training University, Tehran, Iran, in 1987, her MSc. degree in Organic Chemistry from the Teacher Training University, Tehran, Iran, under the supervision of Professor Jafar Asgarian and Professor Mohammad Ali Bigdeli in 1991 and her PhD. degree in asymmetric synthesis (Biotransformation) from Laval University, Quebec, Canada under the supervision of Professor Chenevert, in 2000. She is Associate Professor in the Science faculty of Alzahra University. Her research interests include organic synthesis, heterocyclic synthesis, asymmetric synthesis, natural products synthesis, synthetic methodology and applications of nanoheterogeneous catalysts in multicomponent reactions. 


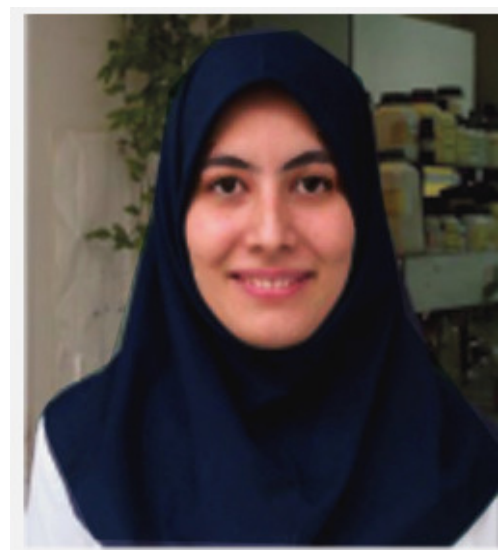

Parisa Gholamzadeh was born in 1986 in Tehran, Iran. She received her B.Sc. and M.Sc. degrees from Alzahra University (2010 and 2012, respectively). Presently she is working towards her PhD. Degree in Organic Chemistry at Alzahra University under the supervision of Dr. Ghodsi Mohammadi Ziarani. Her research field is the synthesis of oxindole based heterocyclic compounds and application of heterogeneous catalysts in organic synthesis and multicomponent reactions.

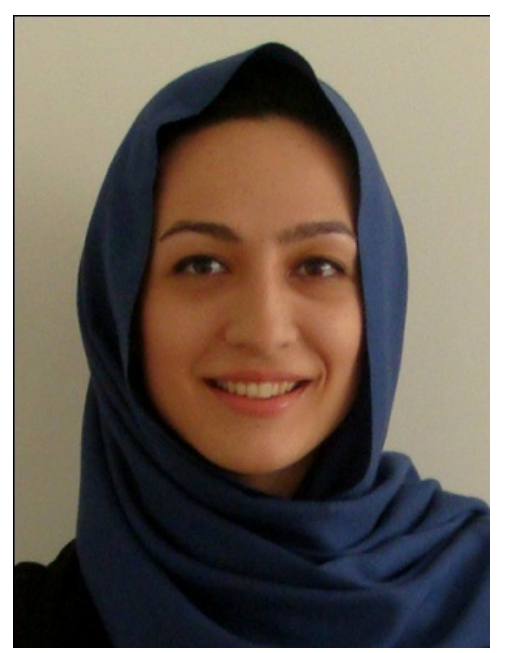

Negar Lashgari was born in 1985 in Tehran, Iran. She received her B.Sc. degree in Applied Chemistry from Teacher Training University, Tehran, Iran (2008) and her MSc. degree in Organic Chemistry at Alzahra University, Tehran, Iran (2011) under the supervision of Dr. Ghodsi Mohammadi Ziarani. She is currently working towards her PhD. in Nano-Chemistry at University of Tehran under the supervision of Dr. Alireza Badiei and Dr. Ghodsi Mohammadi Ziarani. Her research field is synthesis and application of nano-heterogeneous catalysts in multicomponent reactions. 


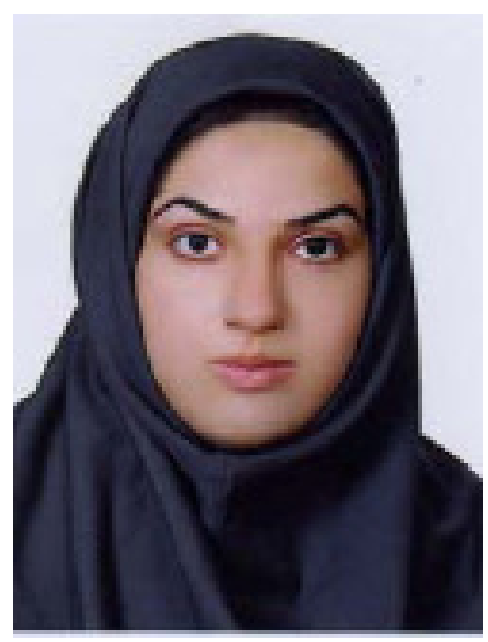

Parvin Hajiabbasi was born in1984 in Babol, Mazandaran, Iran. She received her B.Sc. and M.Sc. degrees from Tehran University (2006 and 2008, respectively). She admitted as a Ph.D student in organic chemistry at Alzahra University, Tehran, Iran in 2010. She is presently enduring her researches in heterocyclic synthesis, synthetic methodology and applications of nano-heterogeneous catalysts in multicomponent reactions under supervision of Dr. Ghodsi Mohammadi Ziarani. 